\title{
Ambulatory blood pressure measurements in stroke patients : the role of blood pressure profile in the determination of brain infarct subtype
}

Citation for published version (APA):

de Wilde, A. (2000). Ambulatory blood pressure measurements in stroke patients : the role of blood pressure profile in the determination of brain infarct subtype. [Doctoral Thesis, Maastricht University]. Universiteit Maastricht. https://doi.org/10.26481/dis.20000101aw

Document status and date:

Published: 01/01/2000

DOI:

10.26481/dis.20000101aw

Document Version:

Publisher's PDF, also known as Version of record

Please check the document version of this publication:

- A submitted manuscript is the version of the article upon submission and before peer-review. There can be important differences between the submitted version and the official published version of record.

People interested in the research are advised to contact the author for the final version of the publication, or visit the DOI to the publisher's website.

- The final author version and the galley proof are versions of the publication after peer review.

- The final published version features the final layout of the paper including the volume, issue and page numbers.

Link to publication

\footnotetext{
General rights rights.

- You may freely distribute the URL identifying the publication in the public portal. please follow below link for the End User Agreement:

www.umlib.nl/taverne-license

Take down policy

If you believe that this document breaches copyright please contact us at:

repository@maastrichtuniversity.nl

providing details and we will investigate your claim.
}

Copyright and moral rights for the publications made accessible in the public portal are retained by the authors and/or other copyright owners and it is a condition of accessing publications that users recognise and abide by the legal requirements associated with these

- Users may download and print one copy of any publication from the public portal for the purpose of private study or research.

- You may not further distribute the material or use it for any profit-making activity or commercial gain

If the publication is distributed under the terms of Article 25fa of the Dutch Copyright Act, indicated by the "Taverne" license above, 


\section{Ambulatory Blood Pressure Measurements in Stroke Patients}

The role of blood pressure profile in the determination of brain infarct subtype 


\section{Promotores:}

Prof. dr. J. Troost

Prof. dr. P.W. de Leeuw

Co- promotor:

Dr. J. Boiten (St. Anna ziekenhuis Geldrop)

Beoordelingscommissie:

Prof. dr. H.F.P. Hillen (voorzitter)

Dr. P. Hofman

Prof. dr. L.J. Kapelle (Universiteit Utrecht)

Prof. dr. J.A. Knottnerus

Prof. dr. Th. Thien (Katholieke Universiteit Nijmegen) 


\section{DANKWOORD}

Een proefschrift schrijf je niet alleen. De weg van de eerste voorbereidingen naar het boekje dat voor $u$ ligt is lang en vol hindernissen. Het is dus een geweldige ervaring waarvoor ik op veel momenten dankbaar ben.

Heel veel mensen hebben bijgedragen aan het voltooien van de studie. Ik denk aan alle patiënten, die, op een moment dat zij het zelf erg moeilijk hadden, toch hun toestemming gaven voor deelname aan deze studie. Ik bedank ook mijn promotoren, professor Troost en professor de Leeuw, voor de gelegenheid om het proefschrift met succes af te ronden. Jelis en Fons, dank voor alle geduld en voor het feit dat jullie in mei 1999 alles nog eens over een andere boeg gooiden! Jan, een half uur praten op de poli resulteerde voor mij in een heel hoofdstuk! Uiteraard kon de studie niet zonder het succesvol schipperen met de apparatuur van het hypertensielab; een kunst die niet zonder de enthousiaste dames daar kon worden beoefend. Het geduld van de verpleegkundigen en artsen op de afdeling was onuitputtelijk.

Inspiratie krijg je ook van buitenaf. Mijn ouders en broers zijn onmisbaar geweest door hun interesse en vertrouwen. Hen, en al mijn vrienden die mij altijd motiveerden kan ik alleen beloven dat ik nu weer meer tijd heb! Mama en papa: een goed glas wijn en een goed gesprek, winkelen en de piano. Pieter- Jan, je belt altijd op het goede moment. Thomas: jouw indruk is altijd origineel. Patrick, veel overleg met koffie was essentieel. Ardi, je staat altijd klaar, en het is geweldig om op je te kunnen rekenen. Peter: een beschouwende blik en een koel biertje.

Frank, met jou is 'mijn hart' nooit 'bang' en is de Macarena nooit afgelopen. Ik vraag niet waar je was, de afgelopen 27 jaar, maar waar zijn wij samen over 27 jaar? Dank je voor je liefde en inspiratie de afgelopen 4 jaar.

Voor Ingetje Blaauw - de Wilde, zo trots.

Voor Frank, zo lief. 


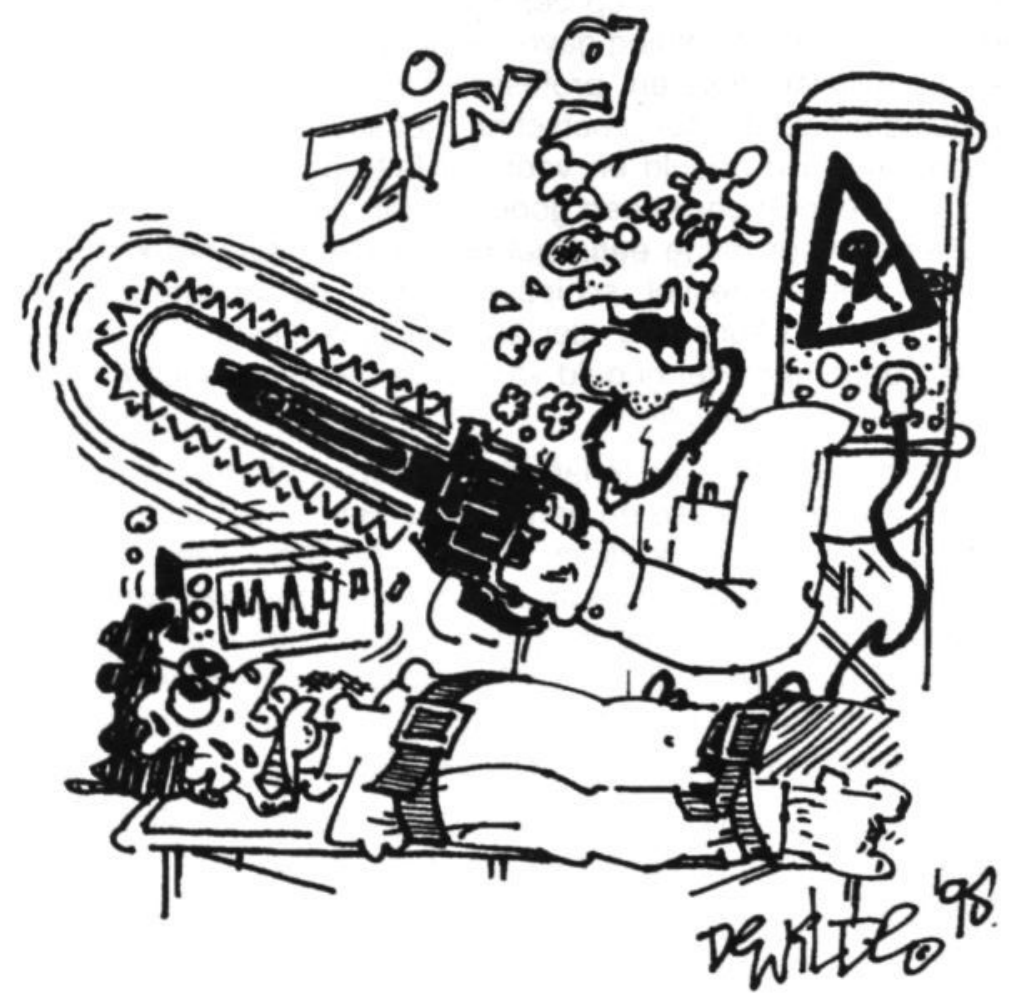




\section{TABLE OF CONTENTS}

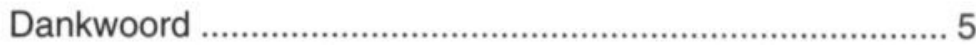

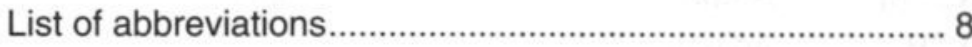

General introduction .......................................................... 9

Chapter 1: Hypertension and the brain: a review of the literature ........ 13

Chapter 2: Patients and methods ......................................................... 29

Chapter 3: Does post-stroke blood pressure reliably reflect prestroke blood pressure?

Chapter 4: Do ambulatory blood pressure measurements in the acute phase of stroke predict blood pressure in the chronic phase of stroke?

Chapter 5: Severity of hypertension as a determinant of the type of stroke: impact of daytime versus nighttime pressure

Chapter 6A: Blood pressure variability and stroke: Blood pressure variability in relation to stroke subtype.

Chapter 6B: Blood pressure variability and stroke: The level of blood pressure and its variability in relation to the type of lacunar stroke

Chapter 6C: Blood pressure variability and stroke: The level of blood pressure and its variability in relation to the extent of white matter lesions and periventricular hyperintensities ... 93

Chapter 6D: Blood pressure variability and stroke: Nocturnal dipping is associated with the stroke lesion site............................. 103

General discussion ............................................................ 109

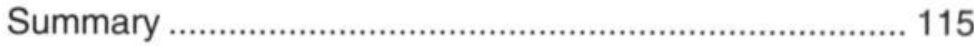

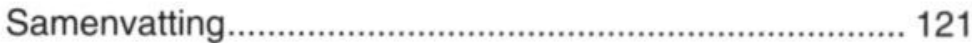

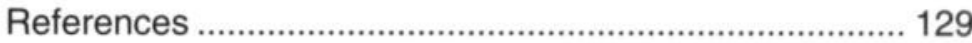




\section{LIST OF ABBREVIATIONS}

$\begin{array}{ll}\text { ABPM } & \text { Ambulatory Blood Pressure Monitoring } \\ \text { AOR } & \text { Adjusted Odds Ratio } \\ \text { CHD } & \text { Coronary Heart Disease } \\ \text { CI } & \text { Confidence Interval } \\ \text { CT } & \text { Computed Tomography } \\ \text { DBP } & \text { Diastolic Blood Pressure } \\ \text { ECG } & \text { Electro Cardio Gram } \\ \text { HBF } & \text { Hemispheric Blood Flow } \\ \text { HR } & \text { Heart rate } \\ \text { ICP } & \text { Intra Cranial Pressure } \\ \text { IOH } & \text { Isolated Office Hypertension } \\ \text { ISH } & \text { Isolated Systolic Hypertension } \\ \text { JNC } & \text { Joint National Committee on Detection, Evaluation and } \\ & \text { Treatment of High Blood Pressure } \\ \text { LACI } & \text { Lacunar Infarct } \\ \text { LVD } & \text { Large Vessel Disease } \\ \text { MAP } & \text { Mean Arterial Pressure } \\ \text { MBP } & \text { Mean Blood Pressure } \\ \text { MRI } & \text { Magnetic Resonance Imaging } \\ \text { PVH } & \text { Peri Ventricular Hyperintensities } \\ \text { rCBF } & \text { regional Cerebral Blood Flow } \\ \text { SBP } & \text { Systolic Blood Pressure } \\ \text { SPECT } & \text { Single Photon Emission Computed Tomography } \\ \text { SVD } & \text { Small Vessel Disease } \\ \text { TE } & \text { Echo Time } \\ \text { TERRI } & \text { Territorial infarct } \\ \text { TIA } & \text { Transient Ischaemic Attack } \\ \text { TOD } & \text { Target Organ Damage } \\ \text { TR } & \text { Repetition Time } \\ \text { WHO } & \text { World Health Organisation } \\ \text { WML } & \text { White Matter Lesions } \\ \text { Xe } & \text { Xenon } \\ & \end{array}$




\section{GENERAL INTRODUCTION}


Hypertension is the most important risk factor for ischaemic and haemorrhagic stroke $[1,2,3,4,5,6]$. The age-adjusted relative risk of stroke in hypertensive persons as compared to normotensive persons is about 3. Sixty percent of all strokes in the population are attributable to hypertension [7]. In 1998, 1 of every 10 deaths in the Netherlands was due to stroke, and care for surviving stroke patients costs $3.2 \%$ of the national health budget $[8,9]$.

Treatment of hypertension has been associated with a reduction in the age-adjusted prevalence of hypertension from about 36\% in 1973 to $20 \%$ in 1993, and a reduction in the incidence of stroke and coronary heart disease (CHD). Age-adjusted systolic blood pressure (SBP) and diastolic blood pressure (DBP) were reduced by $3-6$ and $6-9 \mathrm{~mm} \mathrm{Hg}$ respectively. However, hypertension control has not been improving at the same rate recently [10]. Age-adjusted stroke mortality rates have plateaued or even increased [10, 11], and a greater burden of CHD and stroke is expected in the near future. So, treatment of hypertension and prevention of stroke continues to be a relevant and world-wide concern.

Earlier studies investigating the relationship between stroke and hypertension have often used single post-stroke office blood pressure measurements. However, twenty-four hour ambulatory blood pressure monitoring (ABPM) using a portable device has several important advantages. It is an accurate and non-invasive method, allowing multiple blood pressure readings closely related in time and allowing to assess also variability of blood pressure and its diurnal rhythm. Furthermore, the values obtained by ABPM correlate better with target organ damage (TOD) and mortality than office readings. Finally, isolated office hypertension $(\mathrm{IOH})$ or the white coat effect is avoided and patients may be studied during their normal daily activities $[12,13,14,15,16,17,18]$. We therefore used 24-hour ABPM in our study.

Although hypertension has traditionally been regarded as a specific risk factor for lacunar infarction (LACI) [19, 20, 21, 22], more recent clinical studies $[23,24,25]$ have shown that the incidence of hypertension did not differ between patients with $\mathrm{LACl}$ and patients with territorial infarcts (TERRI). However, these studies used single blood pressure measurements, while, as discussed above, ambulatory blood pressure measurements have several important advantages. We therefore investigated differences in blood pressure profile between patients with $\mathrm{LACl}$ and those with TERRI using ambulatory blood pressure measurements (chapters 5 and 6A).

Recently, the existence of two clinically distinct lacunar infarct entities was postulated, namely multiple lacunar infarcts versus single lacunar infarct. It has been found that patients with multiple LACI more often have 
hypertension [26]. However, this finding also came from a study only using single blood pressure measurements. We therefore compared blood pressure characteristics in these lacunar stroke subgroups using 24-hour ambulatory blood pressure measurements (chapter 6B).

About $25 \%$ of stroke patients have hyperintense lesions in the cerebral white matter on brain imaging, the so-called white matter lesions (WMLs). WMLs are associated with vascular risk factors. Some studies have reported an association between WMLs and hypertension, while others have not. Moreover, some studies have reported that WMLs are associated with the absence of a diurnal blood pressure rhythm, whereas other studies pointed towards extreme nocturnal dipping as a risk factor for WMLs. We tried to solve this discrepancy by investigating blood pressure profiles, using ambulatory blood pressure measurements, in stroke patients with and without WMLs (chapter 6C).

Like most other investigators, we studied the relationship between blood pressure and stroke by using post-stroke blood pressure measurements. The reasons for using post-stroke measurements were twofold. Firstly, pre-stroke measurements were in many cases not available. Secondly, post-stroke measurements were 24-hour ambulatory as well as measurements, available for each patient. Since we did not know, however, whether the post-stroke measurements reliably reflected the pre-stroke situation, we compared our post-stroke office blood pressure measurements with pre-stroke office measurements in a subgroup of patients in whom pre-stroke measurements were available (chapter 3 ).

We performed blood pressure measurements in the chronic phase, six weeks after the stroke. We expected the 24- hour blood pressure profile to have reached a steady state. In the acute phase of stroke, a transient rise in blood pressure may occur that probably levels off and may decrease to pre-stroke levels. The question is whether this decrease in blood pressure has already occurred in the subacute phase. The advantage of characterising a patient's blood pressure profile in the subacute phase of stroke is that this allows any treatment necessary to be started as soon as possible, while the patient is still in hospital. Stabilisation of the blood pressure profile at this stage would mean that subacute measurements during the hospital stay could be used to assess whether a patient has hypertension, so waiting until the chronic phase before starting treatment would not be necessary. We investigated whether blood pressure characteristics had already stabilised in the subacute phase by comparing ambulatory blood pressure measurements in the subacute and chronic phases (chapter 4).

The stroke lesion site may determine post-stroke blood pressure characteristics. In the subacute phase of stroke, patients with right-sided 
cortical infarcts are known to have an increased risk of cardiac arrhythmia and cardiac ischaemic changes, due to autonomic dysfunction [27, 28, $29,30,31,32$ ]. The question remains whether this is a transient or longterm change. We therefore investigated blood pressure profile in patients with stroke lesions at different sites in the acute and chronic phases of stroke (chapter 6D).

Finally, in this thesis we aimed to study the relationship between several blood pressure characteristics and ischaemic stroke. We studied the level of blood pressure, blood pressure variability and diurnal blood pressure rhythm in a prospective and consecutive series of 100 stroke patients. Furthermore, we investigated whether the blood pressure profile differed between the various subtypes of ischaemic stroke.

The specific aims of the study can thus be summarised as follows:

1. To investigate how closely post-stroke office blood pressure reflects pre-stroke blood pressure (chapter 3).

2. To investigate whether ambulatory blood pressure characteristics measured in the subacute phase of stroke are similar to those measured in the chronic phase (chapter 4).

3. To study blood pressure levels using 24-hour ambulatory measurements in various subgroups of brain infarct patients and comparing them with those in healthy volunteers and in patients with $\mathrm{LACl}$ compared to patients with TERRI (chapter 5).

4. To determine blood pressure variability and aspects of diurnal rhythm in various groups of brain infarct patients and controls using 24-hour ambulatory measurement. We compared infarct patients with controls and LACI patients with TERRI patients (chapter 6A).

5. To investigate whether blood pressure profiles differ between the two lacunar infarct entities (chapter 6B).

6. To study the ambulatory blood pressure characteristics of stroke patients with white matter lesions (chapter 6C).

7. To study whether blood pressure characteristics are related to the location of the brain infarct (chapter 6D). 
Chapter 1: Hypertension and the brain: A REVIEW OF THE LITERATURE 


\section{EPIDEMIOLOGY OF HYPERTENSION}

\section{Definition and proposed classification of hypertension}

Various methods that may be used to classify blood pressure have been described $[10,33,34,35,36,37,38]$. The threshold level for blood pressure values that are considered too high has decreased as more has become known about risk association and the effects of treatment [10, 33, 39]. Therefore, the definition of hypertension has changed.

Table one summarises the proposed classification systems of blood pressure levels as measured at home, clinically (according to various classification systems) and by ambulatory measurement. A distinction has been made between values interpreted as normal and hypertensive and values associated with Target Organ Damage (TOD).

\section{Prevalence of hypertension}

Hypertension, defined as a systolic blood pressure (SBP) of more than $140 \mathrm{~mm} \mathrm{Hg}$ or a diastolic blood pressure (DBP) of more than $90 \mathrm{mmHg}$ or both, is a common condition. It occurs in 54\% of Americans aged $65-74$ [3]. The prevalence of hypertension increases with age, from $4 \%$ in Americans aged 18 - 29 yrs to $65 \%$ in those aged 85 yrs and older. The age-adjusted prevalence of hypertension in the US population is about $20 \%$ [39].

In the Netherlands, the prevalence of hypertension increases with age from $2.5 \%$ in subjects aged $25-30$ to $42.2 \%$ in subjects aged $75-80$ (excluding subjects with dementia or overt cerebrovascular disease) [40, 41]. As a consequence, the number of episodes of general practitioner care related to hypertension increases with age [42]. Prevalence of hypertension is high in comparison with its incidence, which means that long-term care must often be provided [43].

In young adults and in early middle age, hypertension occurs more often in men than in women. Thereafter, this relationship reverses. Besides age and gender, other risk factors for increased blood pressure levels are genetic factors, physical activity, body weight, nutritional factors, psychological aspects, alcohol consumption, environmental factors and socio-economic status [7, 33, 44, 45, 46, 47, 48, 49].

Thus, hypertension is a common condition, requiring a great deal of longterm medical care. 


\section{Blood pressure as a vascular risk factor}

Hypertension is an important and treatable risk factor for vascular disease in general. Moreover, it is the most important risk factor for ischaemic and haemorrhagic stroke. The vascular risk increases with increasing blood pressure level and variability $[1,2,4,16,50,51]$. The association of DBP with the incidence of stroke and coronary heart disease (CHD) in large populations has been assessed in a meta-analysis of nine large prospective observational studies [1]. A total of 420,000 individuals were involved, of whom 843 had strokes and 4865 had $\mathrm{CHD}$ events during the follow-up period of 6-25 years. There was a tenfold increase in the relative risk of stroke in the range of DBP studied $(76-105 \mathrm{~mm} \mathrm{Hg})$. The relative risk of $\mathrm{CHD}$ quadrupled in the same range (figure 1 [1]).

Isolated Systolic Hypertension (ISH) is a condition defined as SBP $>160$ $\mathrm{mm} \mathrm{Hg}$, with DBP $<90 \mathrm{~mm} \mathrm{Hg}$. It is especially prevalent in the aged. ISH is associated with a high risk of CHD, and is a more important risk factor for stroke than raised DBP $[3,5,6,52,53]$.

The risk of raised DBP and SBP has been confirmed in studies involving treated and untreated individuals $[4,7,39,48,54]$, and in a retrospective study $[40,41]$ comparing subjects with and without cardiovascular disease. Even in older age groups, hypertension, as well as other risk factors, continues to raise the risk of atherosclerosis [55, 56, 57]. As stated above, $\mathrm{IOH}$ is also associated with TOD [52].

Apart from the actual blood pressure level, short-term variability and the nocturnal blood pressure decline (dip) are also related to TOD [12, 58, 59, $60,61,62,63,64]$. For an individual patient, irrespective of his blood pressure level, the presence of TOD and additional cardiovascular risk factors such as increasing age, diabetes, smoking and dyslipidaemia further increase the risk of cardiovascular complications [2, 3, 65].

So, hypertension is the most important risk factor for stroke. In addition to blood pressure level, other aspects of the blood pressure profile (such as variability and nocturnal dipping) may contribute to the risk of TOD. 
Figure 1: Relative risk of stroke and coronary heart disease according to level of DBP [adapted from Mac Mahon et al. (see reference 1)]

Stroke and usual DBP

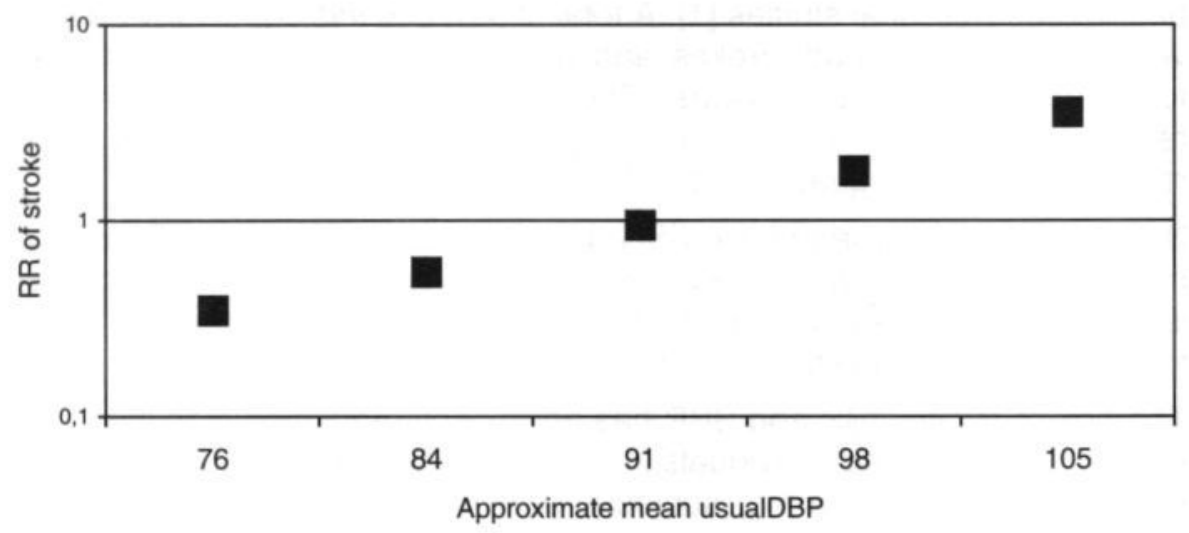

Coronary heart disease and usual DBP

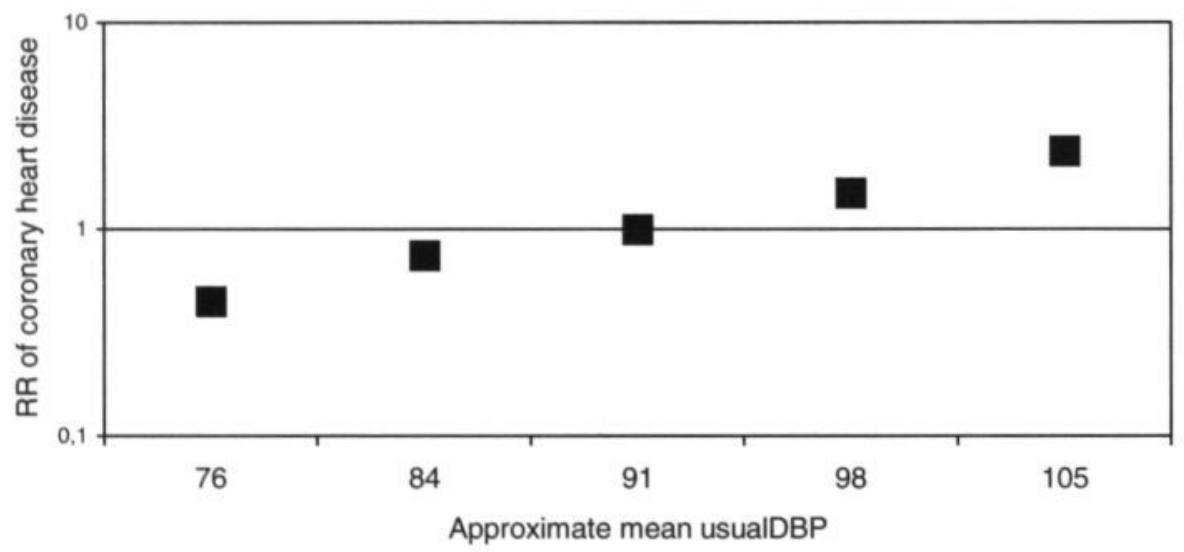




\section{Effect of treatment of hypertension on blood pressure, prevalence of hypertension and incidence of CHD and stroke}

Between 1973 and 1993, mortality from CHD fell by $53 \%$ and that from stroke by $60 \%[33,66,67]$. This was achieved in a period in which awareness, detection and effective treatment of hypertension, including antihypertensive medication, education, and life style adjustment, were improved. The result has been a reduction in the age-adjusted prevalence from about $36 \%$ to $20 \%$, and of the age-adjusted mean SBP and DBP by 3-6 $\mathrm{mm} \mathrm{Hg}$ and by 6-9 $\mathrm{mm} \mathrm{Hg}$ respectively. Randomised controlled treatment trials in elderly hypertensives suggest that there is a direct relationship between treatment efficiency and risk reduction. This applies to $\mathrm{CHD}$ as well as to stroke, and to DBP as well as to ISH [53, $67,68,69$, $70,71,72,73]$. The relative risk reduction is directly related to the decrease in blood pressure level [1] and occurs in the first few years of treatment [66]. The benefit of treatment is greatest for stroke, and applies to the 'normotensive' as well as the 'hypertensive' range of SBP and DBP values. The proportional stroke risk reduction is similar in high-risk and low-risk individuals. In the Netherlands, about 3.5\% of strokes may be attributable to insufficiently controlled hypertension, and $25 \%$ occur in untreated hypertensives [74].

A recent survey in the Netherlands found the incidence and prevalence of "hypertension with end-organ damage" to be relatively low compared to those of "raised blood pressure" or "hypertension", also indicating that TOD is prevented by effective treatment [43].

Even a slight reduction in mean blood pressure would prevent many premature deaths and disabling strokes. Benefits would be greatest in those individuals who are at increased risk of vascular disease due to other disorders, like diabetes, even if they are normotensive. Within the range of $70-110 \mathrm{~mm} \mathrm{Hg}$, no threshold level has been found below which a lower level of usual DBP was not associated with a lower risk [66, 69, 71, 75]. Indirect evidence showing that the steep association slope continues below $70 \mathrm{~mm} \mathrm{Hg}$ has been provided by populations whose usual DBP was $62-66 \mathrm{~mm} \mathrm{Hg}$ and whose incidence of vascular disease was low. Statistical problems (a small number of vascular events at low DBP) and selection bias (inclusion of patients who had experienced a vascular event possibly influencing DBP before baseline blood pressure measurement was performed) explain the suggestion of increased risk at lower blood pressure levels found in some studies, the so-called $\mathrm{J}$ shaped curve phenomenon [76].

Thus, treatment of hypertension has reduced its incidence as well as blood pressure levels. This has resulted in a decreased incidence of CHD and stroke. Recently, however, blood pressure values and age-adjusted 
stroke mortality rates have plateaued or even increased again $[10,11]$. Due to the ageing population and the so-called second epidemic of cardiovascular disease in developing countries, a greater burden of $\mathrm{CHD}$ and stroke is expected world-wide.

\section{Diurnal rhythm and variability of blood pressure}

Blood pressure has a diurnal pattern. Several characteristics of this diurnal blood pressure pattern, such as nocturnal dipping, and short- and long-term blood pressure variability around the mean can be studied. Studies of the 24-hr blood pressure pattern of normotensives, whose blood pressure was measured invasively, showed the highest pressures at mid-morning, after which there was a progressive drop throughout the day. The lowest pressures occurred around 3 a.m., and pressure began to rise in the morning before waking [77]. During sleep, blood pressure normally decreases by $10-20 \mathrm{~mm} \mathrm{Hg}$. This difference between daytime and nighttime blood pressure readings is known as the nocturnal dip. There is a continuous, normal distribution of the nocturnal dip [78].

Superimposed on this pattern are transient variations, which are determined largely by central (autonomic nervous system) and reflex (baroreceptor reflex) influences. These variations are largely related to activity and emotion.

The central nervous system regulates cardiovascular activity by changing arterial blood pressure, vasomotor tone, cardiac rate, cardiac rhythm and cardiac output in response to internal and external stimuli via the autonomic nervous system. This involves preganglionic sympathetic nerve fibres, located mainly in the intermediolateral cell column of the spinal cord and adjacent spinal structures, and preganglionic parasympathetic fibres, located in the dorsal motor nucleus of the nervus vagus and nucleus ambiguus. They receive imput from other central neurones, which themselves receive afferents from peripheral receptors. In addition, there are cortical influences on the sympathetic neurones [79, 80]. Sympathetic control is lateralized in the brain [81, 82]. The right cerebral hemisphere predominantly modulates sympathetic activity [81, 82]. Parasympathetic activity by the nervus vagus causes a decrease in cardiac rate and contractility, whereas sympathetic activity increases cardiac rate and contractility. The interaction between these is such that strong vagal stimulation may attenuate the ability of the sympathetic system to enhance cardiac function [31]. Lesions of any of the structures involved can produce disturbance of the cardiovascular function, causing ischaemia or arrhythmias [29, 30, 83].

In hypertensive patients, the normal pattern may be reset at a higher level, and the nocturnal dip may even be lost $[77,84,85]$. This is clinically 
significant because decreased nocturnal dip and increased variability of blood pressure are associated with an increased risk of TOD [16].

Blood pressure variability increases proportionally with baseline pressure, physical activity and age (only in physically active subjects) [62, 86, 87], and is associated with the presence as well as the subsequent development of TOD $[61,62,63]$. Variability, expressed as a percentage of the baseline pressure (coefficient of variation), remains constant as blood pressure increases [61, 87].

\section{Measurement of blood pressure}

Blood pressure monitoring is used to detect and classify hypertension and to monitor treatment effect. It can be done at home, clinically (using repeated mercury manometer measurements), and with ambulatory methods, using portable, 24-hr measuring devices [34].

There are various reasons why ambulatory blood pressure measurements are preferred in hypertension research. 1) Multiple readings at short time intervals can be obtained, during the daytime as well as during the night. The average blood pressure values are $7-10 \mathrm{~mm}$ $\mathrm{Hg}$ lower than those from office measurements and it is unlikely that the measured values differ greatly from the usual mean blood pressure by chance. 2) Ambulatory blood pressure measurements are more closely related to TOD and mortality than isolated office readings $[12,13,14,15$, 16, 88]. 3) Patients may be studied while performing their normal daytime activities. 4) The alerting reaction to measurement of blood pressure in the doctor's office (white coat hypertension or Isolated Office Hypertension $[\mathrm{IOH}]$ ) is avoided [17, 89]. This is important because, although $\mathrm{IOH}$ is associated with TOD [52], the relationship is not as close as that with sustained hypertension [59, 84].

It has been shown that ambulatory blood pressure measurement by an oscillometric device is feasible in patients with acute stroke or Transient Ischaemic Attack (TIA) [90, 91, 92, 93]. It is superior to casual pressure measurements in predicting the presence of silent lacunar infarcts, as well as the extent of periventricular hyperintensities on Magnetic Resonance Imaging (MRI) of the brain, especially in elderly individuals [13, 59]. 
Table 1 Various proposed classification schemes for hypertension (Data are described as $\mathrm{mm} \mathrm{Hg}$ )

\begin{tabular}{|c|c|c|c|c|}
\hline \multirow[t]{2}{*}{ Criteria } & \multicolumn{2}{|l|}{ Normal } & \multicolumn{2}{|c|}{ Hypertensive } \\
\hline & SBP & DBP & SBP & DBP \\
\hline Home: [38] & $<115$ & $<71$ & & \\
\hline \multicolumn{5}{|l|}{ Office } \\
\hline \multicolumn{5}{|l|}{ classifications: } \\
\hline \multicolumn{5}{|l|}{ WHO [10] } \\
\hline Optimal & $<120$ & $<80$ & & \\
\hline Normal & $<130$ & $<85$ & & \\
\hline High- Normal & $130-139$ & $85-89$ & & \\
\hline Grade 1 & & & $140-159$ & $90-99$ \\
\hline Borderline & & & $140-149$ & $90-94$ \\
\hline Grade 2 & & & $160-179$ & $100-109$ \\
\hline Grade 3 & & & $>180$ & 110 \\
\hline ISH & & & $>140$ & $<90$ \\
\hline Borderline & & & $140-149$ & $<90$ \\
\hline \multicolumn{5}{|l|}{ JNC VI [33] } \\
\hline Optimal & $<120$ & $<80$ & & \\
\hline Normal & $<130$ & $<85$ & & \\
\hline High normal & $130-139$ & 85- 89 & & \\
\hline Stage I & & & $140-159$ & $90-99$ \\
\hline Stage II & & & $160-179$ & $100-109$ \\
\hline Stage III & & & $>180$ & $>110$ \\
\hline \multicolumn{5}{|l|}{ Black [35] } \\
\hline Optimal & $<120$ & $<80$ & & \\
\hline Normal & $120-134$ & $80-85$ & & \\
\hline Stage 1 & & & $135-149$ & 86- 95 \\
\hline Stage 2 & & & $150-180$ & $96-110$ \\
\hline Stage 3 & & & $>180$ & $>110$ \\
\hline \multicolumn{5}{|c|}{ Ambulatory: $[36,37,40,78]$} \\
\hline \multicolumn{5}{|c|}{$24 \mathrm{hr}$} \\
\hline daytime & $115-123$ & $70-76$ & & \\
\hline \multirow[t]{2}{*}{ nighttime } & $101-135$ & $61-89$ & & \\
\hline & $86-127$ & 48- 79 & & \\
\hline
\end{tabular}

In conclusion:

- Hypertension is a common, treatable risk factor for CHD and stroke in all age categories.

- Treatment of hypertension significantly reduces this risk. The risk reduction is achieved within a few years of treatment, so that even treatment in the elderly is worthwhile. No threshold level of blood 
pressure has been found below which treatment does not result in risk reduction, especially for stroke.

- 24-hour ambulatory measurement of the blood pressure profile is an accepted method for studying the relationship between blood pressure characteristics and TOD.

- Epidemiological studies have shown that the occurrence of hypertension and its related complications has levelled off or is even increasing. Therefore the problem of hypertension remains relevant, as its related complications are expected to constitute a substantial disease burden in the near future.

\section{HYPERTENSION AND THE BRAIN}

\section{Cerebral blood flow}

Cerebral Blood Flow (CBF) is kept nearly constant by the so-called cerebral autoregulation. This is a process by which cerebral blood flow is maintained independently of cerebral perfusion pressure as long as this remains between $60-150 \mathrm{~mm} \mathrm{Hg}$. The cerebral perfusion pressure is defined as the Mean Arterial Pressure (MAP) minus the Intracranial Pressure (ICP). As the latter is usually low, CBF varies with MAP [94].

CBF remains constant with age [95, 96, 97], but is decreased in patients with cortical atrophy [98, 99]. In chronic hypertension, the upper and lower limits of autoregulation are raised and cerebrovascular resistance increases. In time, these changes become irreversible. Regional cerebral blood flow (rCBF) is reduced in untreated, neurologically asymptomatic hypertensive patients. During antihypertensive treatment, cerebral blood flow may be restored to normal [100, 101, 102].

If arterial blood flow in the cerebral blood vessels is impaired at any point, a cascade of events results that eventually leads to ischaemia or infarction of the part of the brain relying for its blood supply on the affected vessel [103]. The symptoms of ischaemia are preceded by a decrease in blood flow $[100,104]$.

In the acute phase of ischaemic stroke, autoregulation is impaired. Therefore, CBF in the ischaemic but viable so-called penumbra area surrounding the infarct varies directly with systemic blood pressure. Even a modest reduction in MAP may significantly reduce cerebral blood flow in these patients because stroke patients often have a history of hypertension [105, 106, 107, 108, 109]. Remote effects of stroke on rCBF, known as diaschisis, occur in the contralateral cerebellum, and 
ipsilateral cortex and thalamus $[110,111,112]$. In the subacute phase, luxury perfusion occurs as blood flow is (partially) restored, but autoregulation is still impaired [113].

Thus, CBF is controlled by autoregulation. Untreated hypertension may result in altered limits of autoregulation and reduced CBF. Stroke may result in local and remote changes in rCBF. In the ischaemic area, autoregulation is impaired.

\section{Blood pressure and stroke}

The incidence of first-ever stroke varies world-wide from 135-200 per 100,000 per year. In the Netherlands it is about 145 per 100,000 per year $[8,11,114,115,116,117,118,119]$. The incidence increases rapidly with age $[8,43,115]$. The estimated prevalence of stroke is about 500 700 per 100,000 per year world-wide, whereas in the Netherlands it is 650 per 100,000 per year $[117,120]$. The prevalence increases with age, and leads to increasing episodes of care by a general practitioner $[8,42$, $43,121]$. In the Netherlands 1 of every 10 deaths is due to stroke, and of the deaths due to vascular causes, $25 \%$ are due to stroke. Care for the increasing number of surviving stroke patients is taking up $3.2 \%$ of the health care budget $[8,9]$. In the future, the number of surviving stroke patients is expected to increase because of the development of treatment in the acute phase of stroke, and care in specialised stroke units $[39,122$, $123,124]$. In 2020 , stroke is expected to be the 4th largest contributor to the global burden of disease $[10,57]$.

In the Framingham study [7], the age-adjusted relative risk of stroke in hypertensive persons as compared to normotensives was about 3 . It was estimated that about $60 \%$ of all strokes in the population were attributable to hypertension.

So stroke represents a considerable disease burden, and will continue to do so in the near future. Hypertension is the most important risk factor for stroke.

In the acute phase of stroke, raised blood pressure may occur, which declines spontaneously in the first few days, with little change thereafter. There may be a transient loss of dipping in the acute phase of stroke [ 58 , $125,126,127,128,129,130,131,132]$. One study found that poststroke blood pressure in the chronic phase was lower than pre-stroke blood pressure [127]. Most studies of hypertension and stroke have used post-stroke blood pressure, because pre-stroke blood pressure values are often not available. These studies show that a plateau is reached after 4-10 days in most patients. It is unclear whether blood pressure 
levels measured in the first week after a stroke can predict whether a patient will be hypertensive in the chronic phase of stroke.

The course of blood pressure in the acute phase of stroke is clearly illustrated by the following reported case [90]. A 60-year-old woman underwent 24-hour ambulatory blood pressure monitoring because her hypertension was inadequately controlled. During the 24-hour ambulatory monitoring, she suffered a small, deep right-temporal lobe infarction. Stroke symptoms began around 2 p.m. A hypertensive peak occurred within half an hour after stroke onset, and lasted about 1.5 hours. Thereafter, blood pressure spontaneously declined. This decline, which in some cases may take several days, occurred rather fast. Her blood pressure measurements are shown in graph 1 (adapted from readings given by Nunes et al.).

Graph 1: Blood pressure course during acute stroke (symptoms starting around 14:00) in a 60-year old hypertensive patient

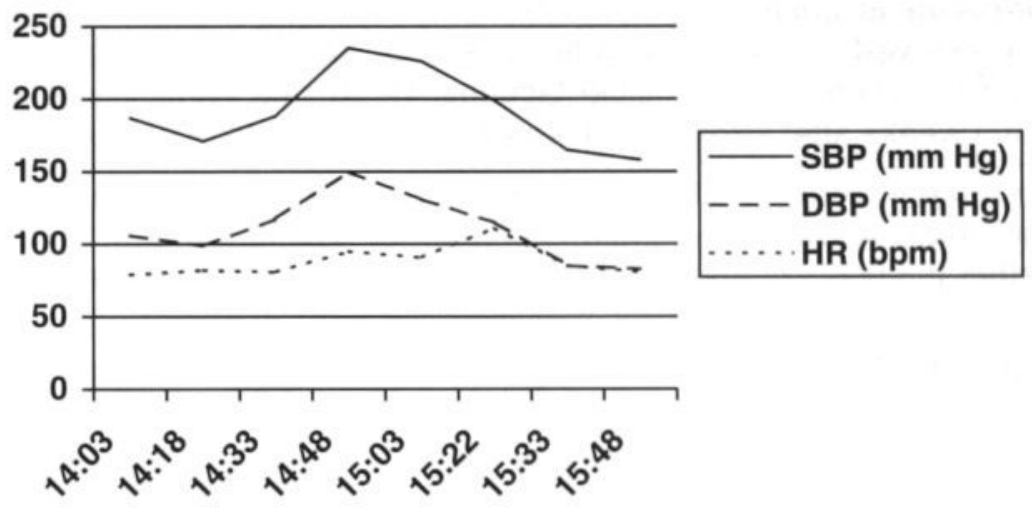

It is still unknown whether the acute rise in blood pressure is the trigger or the result of the stroke $[128,133]$. Most strokes occur between 6 a.m. and noon, suggesting that the physiological rise in morning blood pressure acts as the trigger $[134,135,136]$. On the other hand, increased sympathetic activity may occur after a stroke, especially if the insular cortex is involved. In addition, the baro-reflex control of the heart rate is impaired $[137,138]$. Thus, the lesion itself may cause the acute rise in blood pressure after a stroke $[27,28,29,30,32]$. The above case report 
supports the theory that the raised blood pressure is the result of the stroke.

Patients in the acute phase of stroke show decreased nocturnal dipping. Absence of nocturnal dipping is associated with an increased extent and severity of $\operatorname{TOD}[63,91,139,140]$, and may therefore be the cause of the stroke. On the other hand, absence of nocturnal dipping may also be the result of the stroke, because it is dependent on the type and location of the stroke. Patients with infarcts involving the right insular cortex initially show decreased nocturnal dipping [31, 32, 82, 140,141].

Blood pressure variability is increased in patients with acute stroke [27, $130,142]$, whereas in the acute phase of stroke, heart rate variability is blunted [31, 143, 144, 145]. These phenomena are due to autonomic dysregulation resulting in sympathetic hyperfunction and parasympathetic hypofunction [29, 30, 83, 138, 141,144].

In the chronic phase of stroke, raised blood pressure may occur. This may be a result of the stroke, but it may also be a sign of previously undiagnosed hypertension. The distinction cannot be made if pre-stroke blood pressure is unknown [125, 127, 128]. The nocturnal dipping is usually preserved in patients with a single lacunar infarction and diminished in patients with multiple lacunes. Heart rate variability is still abnormal 3 weeks after stroke, but is restored at 6 months [93, 143, 144].

So the blood pressure profile is different at different stages after a stroke. It is often unknown whether certain changes are due to the stroke itself, and whether the post-stroke profile reflects pre-stroke characteristics.

\section{Hypertension, lacunar infarction and cerebral small vessel disease.}

Stroke comprises a heterogeneous group of disorders. Of all stroke patients, $80 \%$ have ischaemic brain infarction. Of these, $25 \%$ have a small, deep or lacunar infarct, whereas the remaining $75 \%$ have a cortical or large subcortical infarct [24, 26, 116, 146, 147, 148].

Hypertension has been regarded as a specific risk factor for lacunar infarction. This view was based on pathological studies by Fisher [19, 20, $21,22,149,150]$. In his first pathological study, 111 of 114 patients $(97 \%)$ with lacunes were hypertensive [20,149]. However, later clinical studies showed that many patients with lacunar infarction do not have hypertension $[8,25,106,151,152,153,154,155]$. In these clinical studies, the frequency of hypertension in lacunar stroke patients varied between 44 and $75 \%$ [25, 156]. In fact, the prevalence of hypertension in lacunar infarct patients did not differ from that in patients who had suffered a non-lacunar brain infarct $[25,156]$. Patients with hypertension 
therefore seem no more likely to develop lacunar than non-lacunar infarction. How can this discrepancy with regard to differing frequencies of hypertension between Fisher's pathological studies and the subsequent clinical studies be explained? A possible explanation has been offered by Boiten et al. [26, 146], who proposed the existence of two lacunar infarct entities, resulting from two different subtypes of cerebral small vessel disease, which are differentially related to hypertension.

Lacunar infarcts may be caused by two subtypes of cerebral small vessel disease, namely microatheromatosis and lipohyalinosis [157, 158, 159]. In microatheromatosis, a small atheromatous plaque or microatheroma occludes the origin of a small perforating arteriole. The microatheroma resembles the atheromatous plaques in large arteries, with only the diameter of the affected artery being different. Therefore, the risk factors for these small vessel atheromas are probably similar to those of the large vessel atheromas. Occlusion of a small arteriole by a microatheroma usually results in a symptomatic, lacunar infarct. In lipohyalinosis, there is segmented vessel wall destruction with hyaline deposits in the arterial vessel wall, leading to narrowing of the lumen. Unlike microatheromatosis, in which only one of the arterioles occludes, lipohyalinosis is a generalised cerebral small vessel disease and therefore usually causes multiple lacunar infarcts.

Lipohyalinosis in particular is specifically related to hypertension, whereas microatheromatosis has a similar vascular risk factor profile as large vessel atherosclerosis. Therefore, differences in the frequencies of hypertension between the pathological studies conducted by Fisher and the clinical studies may be explained by the fact that the pathological studies mainly included patients with lipohyalinosis and the clinical studies mainly patients with microatheromatosis.

We discussed that hypertension seems no more likely to cause lacunar than non-lacunar infarction. However, the severity and duration of hypertension may also be an important factor in the causation of vessel disease. Fisher [19] suggested that the severity of hypertension might determine the type of cerebral small vessel disease. However, the relationship between the type of stroke and the underlying vasculopathy and the severity of hypertension has scarcely been investigated.

\section{White matter lesions}

CT and MRI scans allow lesions to be identified in the subcortical white matter. On CT-scans, these lesions may be focal or diffuse and are hypointense; this condition has also been termed leukoaraiosis. On MRI scans, white matter lesions (WMLs) are hyperintense on proton-density and T-2 weighted scans involving the cerebral white matter $[160,161$, 
162, 163]. WMLs have to be distinguished from periventricular hyperintensities (PVHs), defined as hyperintense caps around the frontal ventricular horns, or periventricular lining. The latter have no pathological significance and no ischaemic origin $[164,165,166,167,168,169,170$, $171,172,173,174,175,176]$.

The prevalence of WML is $22-27 \%$ in the general population $[80,162$, $177,178]$. The severity of WML increases with vascular risk factors such as age, history of symptomatic stroke, asymptomatic stroke, myocardial infarction, forced expiratory volume, income, atherosclerosis, factor VIIIc activity, fibrinogen levels, diabetes mellitus and plasma cholesterol levels $[80,146,177,179,180,181,182,183,184,185,186,187]$. Some studies have suggested that a history of hypertension, raised blood pressure level and absent or extreme nocturnal pressure decline are risk factors for WML $[13,64,168,169,181,188,189,190]$. Other studies [191] have disagreed and do not identify hypertension as a risk factor for WML. Clinical and population-based studies show that the extent of WML differs between normotensives, regularly treated hypertensives, and irregularly or untreated hypertensives [192].

Pathological studies have shown that WMLs are associated with arteriolosclerosis and ischaemia. However, the affected arterioles are not the same as those involved in the development of multiple lacunar infarcts [160, 161, 167, 193, 194, 195, 196, 197]. WMLs progress over time, especially in patients with symptomatic lacunar infarction. Other factors associated with progression are old age and the presence and progression of silent deep, small infarcts [26, 106, 191,198]. WMLs are associated with cerebral atrophy, a reduction in CBF in the white matter and a decreased dilatory capacity of the cerebral blood vessels $[80,101$, $106,166,180,181,182,183,187,191,199]$. The latter could not be confirmed in another study [181], but this study used 99mTcHMPAO (Technetium Hexamethyl Propylinamine Oxime) and SPECT, which is less suitable than xenon [Xe] for the quantitative measurement of CBF in white matter. There is a decreased vasodilatory capacity and compensatory vasodilatation in asymptomatic patients with WMLs, showing impaired haemodynamic reserve [199].

So several blood pressure characteristics are associated with the occurrence of WMLs. Both extremes of nocturnal dipping reportedly cause increased WMLs. Blood pressure level, but not a history of hypertension, is associated with the extent of WMLs. Further study of blood pressure profiles and the extent of WMLs is needed to resolve this apparent discrepancy. Additionally, light may be shed upon the question whether blood pressure characteristics determine which arterioles are predominantly affected by arteriolosclerosis. 
In conclusion:

- Twenty-four hour ambulatory blood pressure measurement may be used to study the blood pressure profile in stroke patients.

- Hypertension is a risk factor for stroke subtype. Patients with multiple lacunar infarcts report hypertension more often than patients with single lacunar infarcts. We hypothesised that these are two distinct lacunar entities, caused by two different types of cerebral small vessel disease, arteriolosclerosis and microatheromatosis respectively. Apart from multiple LACls, arteriolosclerosis also causes WMLs.

- Additional circumstantial evidence to support this assumption would be provided by the following:

- Differences in the severity of hypertension and other blood pressure characteristics between patients with multiple LACls, and those with single LACls.

- Differences in the severity of hypertension and other blood pressure characteristics according to the severity of WMLs.

- Studies of blood pressure in stroke patients have usually used single, post-stroke blood pressure measurements. However, as stated above, ambulatory measurements have important advantages. Also, it is difficult to determine whether these post-stroke blood pressures reliably reflect pre-stroke blood pressure levels. Moreover, changes in the blood pressure profile may occur after the stroke that may be due to the stroke lesion itself.

- If the blood pressure profile determines the stroke subtype, some patients may need treatment as soon as possible after stroke. It would then be advantageous if blood pressure characteristics, as measured one week after the stroke, could predict the blood pressure profile in the chronic phase of the stroke. 
Chapter 1 
Chapter 2: Patients and methods 


\section{PATIENTS}

All consecutive patients with a first-ever supratentorial brain infarct with symptoms lasting longer than 24 hours or a deep intracerebral haemorrhage who were admitted to the University Hospital of Maastricht (the Netherlands) or visited the out-patient clinic between October 1994 and January 1997 prospectively entered this study. Eligibility for entering the study was assessed as soon as possible after admission.

Patients with a potential cardiac source of embolism or a specific stroke cause such as vasculitis or arterial dissection were excluded, since we wanted to study cerebral small and large vessel disease. Potential cardiac embolic sources included paroxysmal and chronic atrial fibrillation, mitral stenosis, prosthetic aortic or mitral valve, recent $(<6$ weeks) myocardial infarction, endocarditis, cardiomyopathy, left ventricular aneurysm and intraventricular thrombus.

A total of 250 patients were eligible to enter the study during the inclusion period, of whom 150 were subsequently excluded. Reasons for exclusion were symptoms existing more than 5 days at screening time (as additional investigations could, in that case, not be performed in time), severe stroke (patients judged by relatives to be too ill to undergo the ancillary investigations, so that consent was not given), early death and early discharge from the hospital. General characteristics of the group of 150 excluded stroke patients and the group of 100 patients who participated in our study are shown in table 2.1. There was no significant difference in general characteristics between these patient groups.

Table 2.1: General characteristics of the participating and nonparticipating (but eligible) stroke patients

\begin{tabular}{lll}
\hline & Non- participants [N=150] & Participants [N=100] \\
\hline Age & $70(13)$ & $65(13)$ \\
Male gender & $79(53 \%)$ & $56(56 \%)$ \\
Hypertension & $66(44 \%)$ & $45(45 \%)$ \\
Diabetes mellitus & $26(17 \%)$ & $18(18 \%)$ \\
Peripheral and cardiac & $51(34 \%)$ & $45(45 \%)$ \\
vascular disease & & \\
Territorial infarct & $101(67 \%)$ & $56(56 \%)$ \\
Lacunar infarct & $55(37 \%)$ & $38(38 \%)$ \\
\hline
\end{tabular}

* mean (standard deviation)

None of the differences were statistically significant 
Routine investigations for all ischaemic stroke patients included standard blood tests, electrocardiogram, chest X-ray, CT scan of the brain (1-7 days after stroke) and non-invasive carotid studies. In selected cases, echocardiography, 24-hour ECG monitoring or cerebral angiography was performed.

Of the 100 stroke patients who entered the study, 81 underwent both CT and MRI scanning, while 19 patients underwent only CT scanning. The main reason for not undergoing MRI scanning was claustrophobia. We compared MRI diagnosis with CT diagnosis in these 81 patients. There was disagreement in 7 patients, resulting in a kappa of 0.8 , which is generally regarded as good agreement. As both CT and MRI diagnosis were in good agreement, and in order to obtain the largest possible patient group, we used all 100 patients in the subsequent analysis.

\section{CONTROL GROUP}

The control group consisted of 131 healthy volunteers participating in the Maastricht Ageing Study (MAAS) [40, 41, 200, 201]. They were recruited from a register of family practices in the Maastricht region, which is the same region as that of our study patients. The 469 subjects who participated in the MAAS study were stratified into age groups [40]. All age groups were subdivided into subgroups according to sex and general ability (a measure of educational level and professional level). We selected from this group of 469 subjects all individuals who did not have a history of atrial fibrillation, because a potential source of cardiac embolism was one of the major exclusion criteria for our patient group, and also underwent successful 24-hour ambulatory blood pressure measurement (Spacelabs 909207) This left us with 131 subjects.

\section{VASCULAR RISK FACTORS}

The following vascular risk factors were recorded: age, gender, diabetes mellitus (known diabetes mellitus, or fasting serum glucose higher than $7.0 \mathrm{mmol} / \mathrm{l}$, or post-prandial serum glucose higher than $11 \mathrm{mmol} / \mathrm{l}$, both on two separate occasions), hypercholesterolaemia (known hypercholesterolaemia, or serum cholesterol higher than $6.4 \mathrm{mmol} / \mathrm{I}$ ), history of ischaemic heart disease (myocardial infarction or angina pectoris), claudicatio intermittens, and reported smoking habits. Known hypertension and use of antihypertensive medication were recorded. Furthermore, an extensive search for pre-stroke blood pressure data was performed for every patient, using the hospital records as well as records 
kept by the general practitioner. After permission had been obtained from the patient or his family, the general practitioner was asked to search his records for any notes on the patient's blood pressure in the past. This information was provided by telephone or fax. If necessary, we visited the general practitioner and searched the records ourselves. If the patient had visited the hospital, clinical and outpatient records were obtained, and searched for any notes on the patient's blood pressure. Since these data were obtained retrospectively, we cannot exclude the possibility that bias has occurred in the collection of the data and their validity.

From this search, any blood pressure measurement recorded during the five years preceding the stroke was noted for each patient. The mean blood pressure was calculated for each period of 0.5 years, that is, for 0 0.5 year, $0.5-1$ year before the stroke and so on. SBP and DBP were recorded separately. MBP was calculated from SBP and DBP as follows:

$$
\mathrm{MBP}=\mathrm{DBP}+(\mathrm{SBP}-\mathrm{DBP}) / 3 \mathrm{~mm} \mathrm{Hg}
$$

\section{DEFINITIONS}

\section{Stroke}

A stroke was defined as rapidly developing signs of focal disturbance of cerebral function, lasting longer than 24 hours, or leading to death, with no apparent cause other than that of vascular origin [26]. We distinguished between haemorrhagic and ischaemic strokes on the basis of CT or MRI. Two subtypes of ischaemic stroke were distinguished: lacunar stroke and territorial stroke.

\section{Lacunar stroke}

A lacunar stroke (figure 2.1) was defined as

(1) An acute stroke syndrome with a lesion on the CT scan, compatible with occlusion of a single perforating artery, i.e. a small, subcortical, sharply marginated hypodense lesion with a diameter less than $20 \mathrm{~mm}$, or with a lesion on MRI scan, that is, a subcortical lesion (diameter $<20 \mathrm{~mm}$ ), hyperintense on the $T_{2}$-weighted image and with the same intensity as cerebrospinal fluid on $T_{1}$-weighted and proton density images [163, 171, 202].

Or

(2) Clinically, by the presence of a lacunar syndrome, that is unilateral motor and/or sensory signs and symptoms 
involving the whole of at least two of three body parts (face, arm or leg), without loss of consciousness or signs of cortical dysfunction, such as aphasia or a visual field defect, with no specific lesion on CT or MRI scan [20, 21, 22, 24, 26, 191].

Furthermore, we distinguished between two lacunar stroke entities, according to a previous publication [26]:

1. patients with a single, symptomatic lacunar infarct, and

2. patients with multiple lacunar infarcts.

Figure 2.1: MRI and MR- angiography in patients with stroke showing various stroke subtypes and large vessel disease

Lacunar infarct

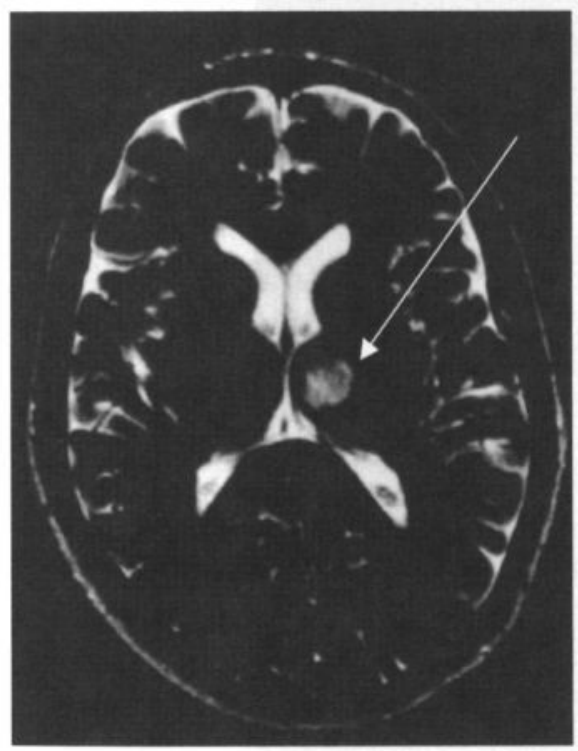

Territorial infarct (narrow arrow) and punctate white matter lesions (broader arrows)

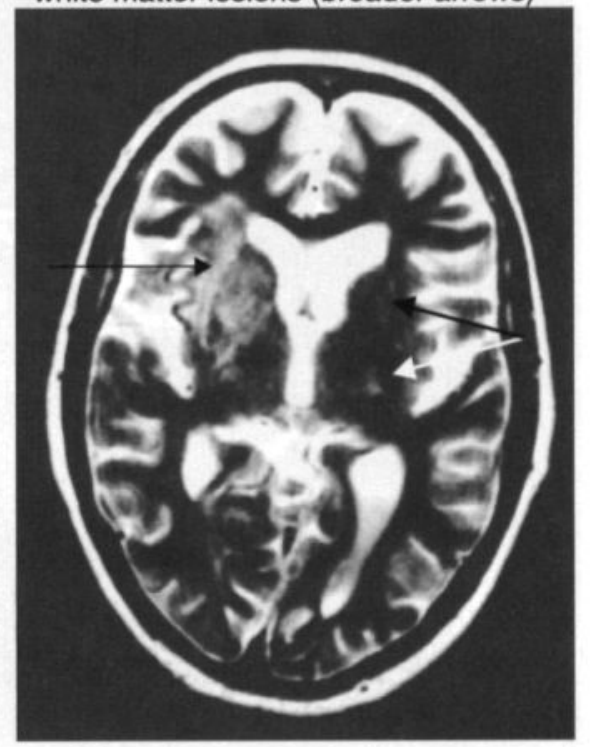




\section{Primary intracerebral hemorrhage}

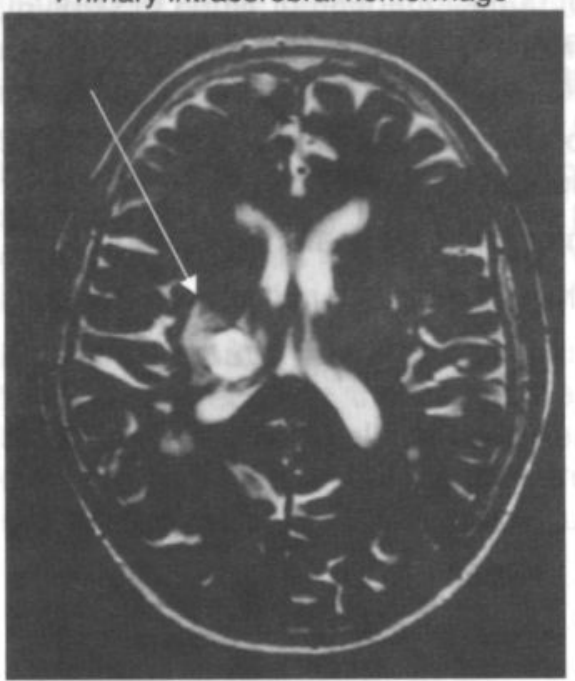

Confluent white matter lesions

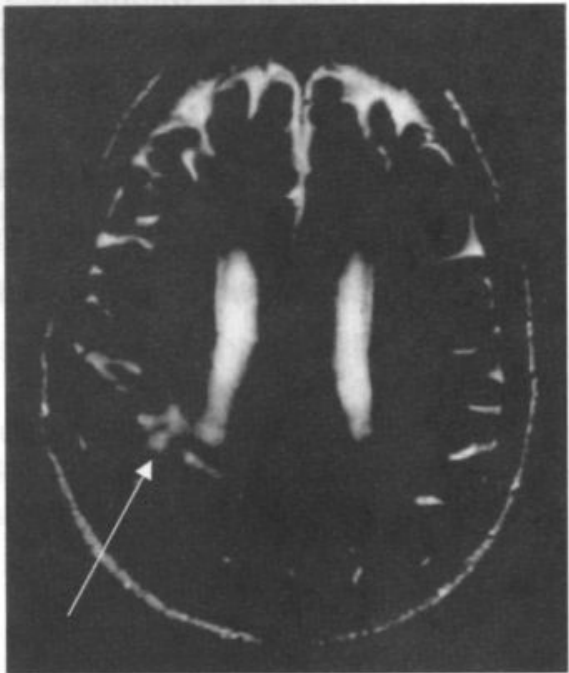

Large vessel disease: Carotid occlusion

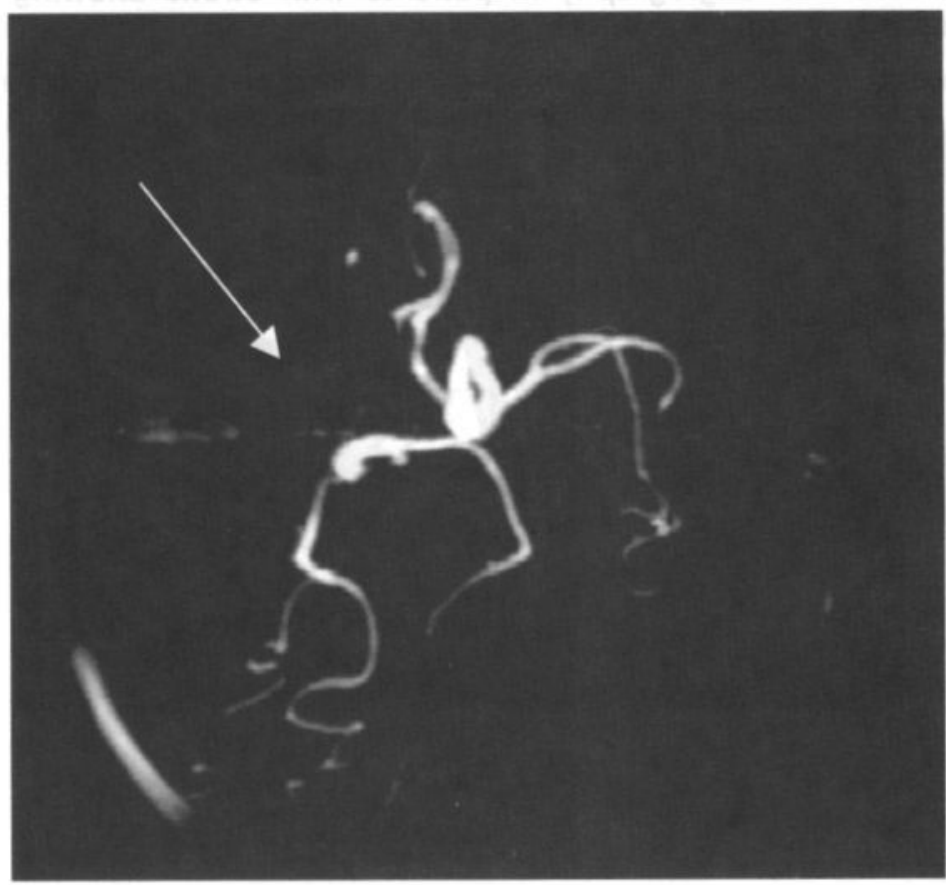


The clinical distinction between these two infarct entities is based on the two pathologically defined small vessel diseases [20, 21, 22]. We presumed, on the basis of previous research, that patients with a single symptomatic infarct suffered from small vessel atherosclerosis or microatheromatosis, and that patients with multiple lacunar infarcts suffered from lipohyalinosis or arteriolosclerosis [26, 146] (see below, under stroke causes).

\section{Territorial stroke}

A territorial stroke (figure 2.1) was defined as

(1) An acute stroke syndrome with a CT scan or MRI compatible with infarction involving the cortex.

Or

(2) Clinically, when no specific lesion was visible on CT or MRI, by unilateral motor and/or sensory symptoms and signs, in combination with signs of cortical dysfunction (e.g. language disturbances), with or without visual field defects, incomplete involvement of two body parts; or isolated monoparesis; or isolated cortical dysfunction (usually aphasia) [146, 147, 153, 163, 174, 184, 203].

Patients with a large subcortical or striatocapsular infarct or centrum ovale infarct were included in this group because of similar pathogenesis [146, 147, 153, 154].

\section{Silent brain infarct}

A silent brain infarct was defined as a low-density area on CT or a hyperintense lesion on MRI, compatible with infarction but without a history of stroke, as shown from the patient's history, from relatives or any other accessible information. Also, the stroke symptoms at study entry had to be anatomically incompatible with this infarct [191].

\section{Haemorrhagic stroke}

We only included patients with a primary intracerebral haemorrhage in the territory of the deep perforating arteries (figure 2.1), that is a lesion on CT or MRI scan, compatible with a haemorrhage and confined to the thalamus, lentiform nucleus, caudate nucleus or internal capsule. 


\section{Stroke causes}

The following stroke causes were distinguished:

\section{Large vessel atherosclerosis or macroatheromatosis}

Large vessel atherosclerosis or macroatheromatosis (figure 2.1) was diagnosed in patients with a territorial infarct who had no potential cardiac embolic stroke cause and irrespective of the presence of a large (pre-cerebral) artery stenosis or occlusion.

\section{Small vessel occlusion}

Small vessel occlusion or small vessel disease was diagnosed in patients who had a lacunar stroke. As described above, we distinguished between two (pathologically defined) types of small vessel disease on the basis of clinical criteria, namely small vessel atherosclerosis (or microatheromatosis) and lipohyalinosis (or arteriolosclerosis).

\section{White Matter Lesions}

White Matter Lesions (WMLs) were defined as hyperintense lesions on proton-density and T2-weighted MRI scans involving the cerebral white matter (figure 2.1). WMLs were rated as follows [160, 167, 193, 196]:

Grade 0: absent

Grade 1: $\quad<=5$ punctate foci (diameter $>2 \mathrm{~mm}$ )

Grade 2: > 5 punctate foci (diameter $>2 \mathrm{~mm}$ )

Grade 3: confluent lesions

Hyperintense punctate foci $>2 \mathrm{~mm}$, which were isointense to cerebrospinal fluid on T1-weighted images, were considered to represent lacunar infarcts. Hyperintense punctate foci $\langle=2 \mathrm{~mm}$ were considered to represent dilated Virchow-Robin spaces (see below).

\section{Periventricular Hyperintensities (PVHs)}

Periventricular hyperintensities (PVH) were distinguished from WMLs because they have no pathological significance and are of non-ischaemic origin $[167,170,175,176]$. PVHs were defined as hyperintense periventricular caps (around the frontal ventricular horns) and periventricular lining (so-called smooth halo).

PVHs were graded as follows [167, 196]:

Grade 0: absent 
Grade 1: periventricular caps and/or pencil-thin lining $(<5 \mathrm{~mm})$

Grade 2: smooth halo $>5 \mathrm{~mm}$ and $<10 \mathrm{~mm}$.

Irregular periventricular hyperintense areas as well as a smooth halo $>10$ $\mathrm{mm}$ in diameter were regarded as WML grade 3 (see above).

\section{AdDitionAL INVESTIGATIONS}

\section{MRI of the brain}

In addition to acute CT scanning, all patients were planned for Magnetic Resonance Imaging (MRI) of the brain. MRI is superior to CT in the detection of infarcts and white matter lesions. There is a good correlation between MRI lesions and pathologic studies [163, 174, 204, 205]. MRI of the brain was planned in the second week after the stroke.

Scanning was performed on a 1.5 Tesla Philips gyroscan. Field of view was $230 \mathrm{~mm}$; scan matrix was $201{ }^{*} 256$. Using an Echo Time (TE) of $120 \mathrm{~ms}$ and a Repetition Time (TR) of $3588 \mathrm{~ms}, 5 \mathrm{~mm}$ contiguous, transverse, $T_{2}$-weighted images were obtained. Using a TR of $3588 \mathrm{~ms}$ and a TE of $20 \mathrm{~ms}, 5 \mathrm{~mm}$, contiguous transverse proton-density images were obtained.

\section{Twenty- four- hour ambulatory blood pressure registration}

Patients underwent 24-hour ambulatory blood pressure registration within the first week after the stroke. This was repeated six weeks after the stroke. The monitor used was a Spacelabs 90207, Spacelabs Inc., Redmond, WA, USA, with a suitable cuff. This is an oscillometric device that measures Mean Arterial Pressure and registers Systolic Blood Pressure and Diastolic Blood Pressure by extrapolation of the signal. The apparatus was programmed to measure blood pressure four times every hour during the day (defined as 7 a.m. to 10:59 p.m.) and twice every hour during the night (11 p.m. to 6:59 a.m.). Before use, the apparatus was calibrated by comparing three ambulatory blood pressure readings with simultaneous measurements using a mercury sphygmo-manometer. For the office measurements, MBP was calculated from SBP and DBP as follows:

$$
\mathrm{MBP}=\mathrm{DBP}+(\mathrm{SBP}-\mathrm{DBP}) / 3 \mathrm{~mm} \mathrm{Hg} .
$$

The following readings were obtained over 24 hours, over the daytime period, and over the nighttime period: mean and standard deviation of SBP, mean and standard deviation of DBP and mean and standard deviation of MBP. These data were used to calculate the nocturnal dip 
(an absolute measure of nocturnal blood pressure decline), that is the difference between daytime and nighttime blood pressure $(\mathrm{mm} \mathrm{Hg})$ for SBP, MBP and DBP as follows: DIP = mean BP (daytime) - mean BP (nighttime). The percentage of dipping, (a relative measure of nocturnal blood pressure decline), that is the nocturnal dip as a percentage of daytime blood pressure (\%), was calculated for SBP, MBP and DBP as follows: PERCENTAGE OF DIPPING = [DIP (BP) / mean BP (daytime)] * 100. Although in the literature, patients are often divided on the basis of an arbitrary degree of dipping (e.g. more or less than $10 \%$ ), we refrained from using such a dichotomy in our analyses, because the degree of dipping is a continuous rather than a dichotomous phenomenon.

Standard deviation was used as a measure of variability. Nocturnal dip and percentage of dipping are aspects of diurnal rhythm.

\section{STATISTICAL METHODS}

For the sake of clarity, the statistical methods used for the analyses in this thesis are described in detail below, and will only be summarised in the relevant chapters.

Baseline characteristics of stroke patients and controls were compared between subgroups of patients using the Mann-Whitney and chi-squared test.

Chapter 3 of this thesis investigates the relationship between pre- stroke and post stroke blood pressure measurements. A paired T-test was performed to assess the difference between post-stroke office blood pressure and pre-stroke blood pressure measurements for each sixmonths period prior to the stroke. Post-stroke office blood pressure was also compared with the average pre-stroke pressure. Finally, post-stroke office blood pressure and post-stroke ambulatory blood pressure were compared using a paired T-test.

Linear regression analysis was used to assess the trend in blood pressure change before the stroke. The slope of the linear regression graph, or beta, was calculated for each patient over the 5 years prior to the stroke as well as for the 2 years prior to the stroke, giving the average change in blood pressure per year. For all stroke patients, and for the subgroups of lacunar infarct (LACI) and territorial infarct (TERRI) patients, a one-sample T-test was done to assess whether the blood pressure change differed significantly from zero. The beta was compared between the stroke subgroups using a T-test. 
Chapter 4 investigates the course of blood pressure characteristics after stroke. To assess whether the blood pressure characteristics in the acute phase of stroke predicted those in the chronic phase, we performed linear regression analysis, and calculated correlation coefficients and prediction intervals (at the mean of the blood pressure characteristics) for blood pressure level, standard deviation, dip and percentage of dipping for each infarct group. We made scatterplots of acute phase blood pressure versus the average of acute and chronic phase blood pressures, to investigate whether intra-individual differences in blood pressure between the acute and chronic phases after the stroke were related to blood pressure level.

Chapters 5 and $6 \mathrm{~A}-\mathrm{C}$ of this thesis investigate the relationship between blood pressure characteristics and brain infarcts, infarct subtypes and WMLs.

\section{Exploratory analysis}

To investigate in stroke patients the relationship between hypertension and ischaemic stroke, we first performed an exploratory analysis. We looked for differences in level, standard deviation, nocturnal dip and percentage of dipping of blood pressure between patients and controls and between patient subgroups. These comparisons were made using a T-test. The standard deviation of blood pressure variations was analysed with a non-parametric (Mann-Whitney) test, because this was not normally distributed.

The reason why we performed this exploratory analysis was to compare our results with those of earlier studies, which also often used T-tests in their analyses. However, there is a shortcoming in this type of analysis. In our hypothesis, blood pressure is the causal factor, and infarct type is the outcome to be predicted. A multivariate analysis (adjusting for confounding), however, requires infarct type to be the dependent variable and blood pressure (or aspects thereof) the independent variable.

\section{Multivariate regression analysis}

We wanted to investigate whether blood pressure is a causal factor for stroke or stroke subtype. To achieve this, multivariate regression analysis was performed. To adjust for confounders, it was important that stroke subtype was the dependent variable in this analysis.

Individuals were divided into tertiles based on level, standard deviation, dip or percentage of dipping of SBP, MBP and DBP for daytime, nighttime and 24-hour blood pressure. This was done because opinions differ about the shape of the curve that describes the relationship between these 
blood pressure characteristics and brain infarcts and WMLs, as described in chapter 1. Although we expected a linear relationship, a J-shaped relationship could not a priori be excluded in our patient group. These tertiles of blood pressure level were taken as independent variables (or risk factors), the lowest tertile acting as a reference for the 2nd and 3rd tertiles. Brain infarct subtype and WML severity were used as the dependent variables (or results).

Because the number of possible confounders was too large to include them all in our logistic regression model, we first included them one by one in a bivariate model to determine which of them had a relevant effect on the crude Odds Ratio (cOR). We regarded a change of more than $10 \%$ as indicative of confounding. We then used the same procedure to look for changes when the resultant confounders were removed one by one. This resulted in the inclusion of age, gender, diabetes, smoking and vascular disease in our final model for multivariate analysis. We corrected for the same confounders in each separate analysis.

\section{Presentation of the results of the multivariate regression analysis}

Table 2.2 shows an example of the division into subgroups for one analysis. We searched for significantly different odds of brain infarct patients in the 2 nd tertile of blood pressure (d versus $\mathrm{c}$ ), compared to the odds in the 1st tertile of blood pressure (b versus $a$ ).

The ratio $d / c: b / a$ is known as the odds ratio and may be mathematically rewritten as ad/bc. In the same way we compared $f$ versus e with $b$ versus a, resulting in odds ratio af : be as presented in figure 2.2.

The results of the logistic regression analysis are presented graphically in each chapter. Figure 2.2 shows an example of such a graph. Horizontal lines represent the confidence interval for each comparison. Hairlines represent the comparison for the 2 nd versus the 1 st tertile, while the thick line represents the comparison for the 3 rd versus the 1 st tertile. The solid squares represent the adjusted odds ratio (aOR) for each comparison. The vertical line is a reference line for $x=1$. If 1 lies within the confidence interval, there is no significant difference. 
Table 2.2: Example of variables used in the multivariate regression analysis

\begin{tabular}{llll}
\hline \multicolumn{4}{l}{ Independent variable } \\
\hline Dependent variable & \multicolumn{4}{l}{ Blood pressure level tertiles } \\
Control or brain infarct & 1st tertile & 2nd tertile & 3rd tertile \\
Control & a & c & e \\
Brain infarct & b & d & f \\
\hline
\end{tabular}

a-f refer to the number of individuals in each tertile

Figure 2.2: Detail of graphical presentation of results of multivariate regression analysis

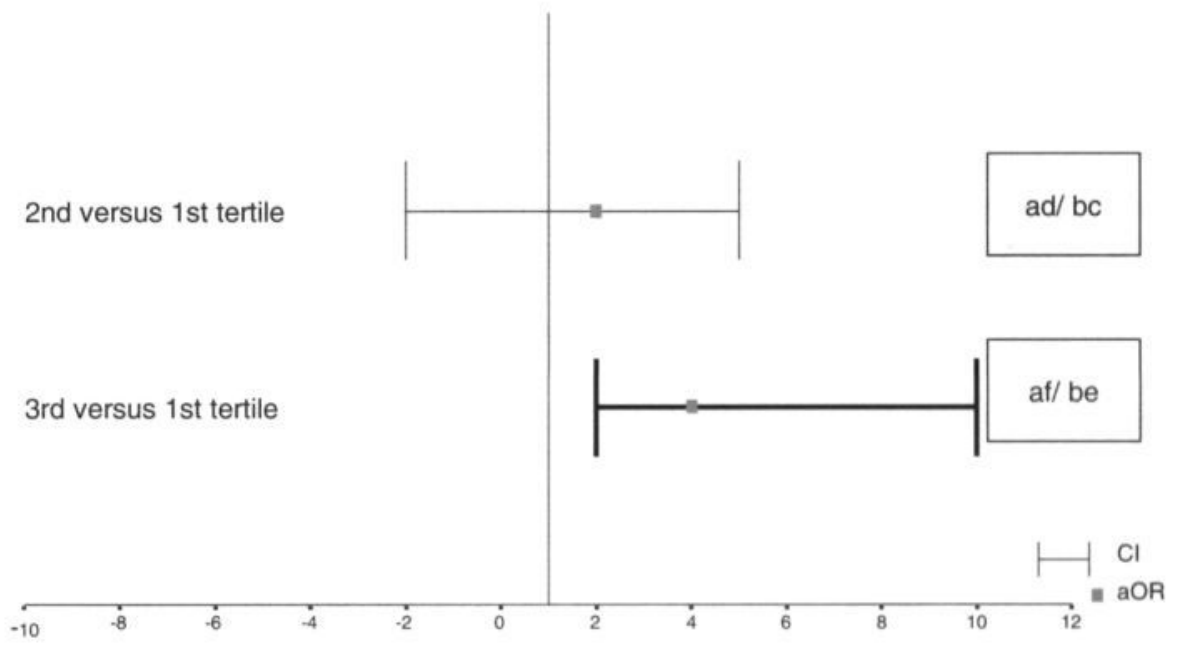

In chapter $6 \mathrm{D}$ we investigate the relationship between stroke lesion site and blood pressure course after stroke. To assess whether the blood pressure characteristics varied between patients with strokes at different sites, we compared blood pressure level, standard deviation, nocturnal dip and percentage of dipping in the acute phase between the patient groups using the T-test. For any significant differences found, we repeated this procedure for the same blood pressure characteristics for measurements taken in the chronic phase of stroke. 
Chapter 2 


\section{Chapter 3: DOES POST-STROKE BLOOD PRESSURE RELIABLY REFLECT PRE- STROKE BLOOD PRESSURE?}

\section{Abstract}

Objective: Most studies investigating the relationship between hypertension and stroke have utilized post-stroke blood pressure measurements. However, it is unknown whether these measurements reflect pre-stroke blood pressure well enough. Therefore, we studied the relationship between pre- and post-stroke blood pressure.

Design and Methods: One hundred stroke patients were included in the study. MRI and CT scans were used to define stroke subtype. Records kept by general practitioners and hospital records were searched for notes on the patient's blood pressure during the 5 years prior to stroke. Post-stroke blood pressure was measured about 6 weeks after stroke using a mercury sphygmomanometer. In addition, 24-hour ambulatory blood pressure was measured at that time. Linear regression was used to study changes in prestroke blood pressure over time and trends were compared between different stroke subgroups (i.e. lacunar or territorial).

Results: We found no blood pressure changes over the 5 years prior to stroke in the $76(76 \%)$ patients in whom pre-stroke measurements were available. Prestroke and post-stroke office measurements did not differ in the entire group of stroke patients, nor when broken down by stroke subgroups. However, in the group of patients in whom pre-stroke blood pressure measurements were available, selection bias may have occurred towards the inclusion of patients who visit their physician regularly because of a history of hypertension or cardiovascular disease.

Conclusions: Post-stroke blood pressure measurements reliably reflect prestroke blood pressure. Blood pressure remained stable over the 5 year period prior to stroke, at least in those stroke patients in whom pre-stroke blood pressure was regularly measured. 


\section{INTRODUCTION}

Hypertension is an important and treatable risk factor for vascular disease in general and for ischaemic and haemorrhagic stroke in. The vascular risk increases with blood pressure level [1, 2, 4, 16, 50, 51].

Most studies that have investigated the relationship between hypertension and ischaemic stroke in stroke patients used post-stroke blood pressure measurements because pre-stroke measurements are often not available or difficult to obtain.

In the post-stroke period, 24-hour ambulatory blood pressure measurements can easily be performed. Ambulatory measurements have important advantages relative to single measurements: $[15,17,18,88$, 89].

1) Multiple readings at short time intervals may be obtained during the daytime as well as during the night. This decreases the probability that the measured values differ greatly from the usual mean blood pressure by chance.

2) Patients may be studied while performing their normal daytime activities.

3) The alerting reaction to measurement of blood pressure in the doctor's office (white coat hypertension or Isolated Office Hypertension $[\mathrm{IOH}])$ is avoided.

Earlier studies have shown that ambulatory blood pressure measurements tend to be lower than office measurements, due to the fact that ambulatory blood pressure measurement allows the average of multiple measurements to be used. The aim of our present study was twofold. Firstly, because we did not know whether post-stroke blood pressure measurements reliably reflect pre-stroke pressure, we investigated the relationship between pre-stroke and post-stroke blood pressure measurements by comparing measurements over the last 5 years preceding the stroke from hospital records and records kept by general practitioners with post-stroke office measurements taken six weeks after the stroke. The second aim of our study was to assess, in stroke patients, the relationship between post-stroke 24-hour ambulatory and post-stroke office blood pressure measurements. 


\section{PATIENTS AND METHODS}

Patients and methods have been extensively described in chapter 2. The following analyses were performed:

1) Difference between post-stroke office blood pressure and prestroke blood pressure measurements for each six-month period prior to the stroke (paired T- test).

2) Comparison of post-stroke office blood pressure and the average pre-stroke blood pressure (paired T- test).

3) Comparison of post-stroke office blood pressure and post-stroke ambulatory blood pressure (paired T-test).

4a) Trend in blood pressure change before the stroke (linear regression analysis).

4b) Significant difference between this blood pressure change and zero (one-sample T-test)

4c) Comparison of this change between stroke subgroups (T-test).

\section{RESULTS}

Of the 100 patients included in the total study, $76(76 \%)$ with an ischaemic stroke had had pre-stroke blood pressure measurements recorded within 5 years prior to their stroke. Of these 76 patients, 32 $(42 \%)$ had a lacunar infarction and $44(58 \%)$ had a territorial infarction. These 76 patients were used in the present study.

Table 3.1: Baseline characteristics according to stroke subtype

\begin{tabular}{llll}
\hline Characteristics & $\begin{array}{l}\text { All infarct patients } \\
\mathrm{n}=76 \mathrm{~N}(\%)\end{array}$ & $\begin{array}{l}\mathrm{LACl} \\
\mathrm{n}=32 \mathrm{~N}(\%)\end{array}$ & $\begin{array}{l}\text { TERRI } \\
\mathrm{n}=44 \mathrm{~N}(\%)\end{array}$ \\
\hline Age $^{\dagger}$ & $66(11)$ & $65(10)$ & $67(12)$ \\
Male gender & $41(55 \%)$ & $16(52 \%)$ & $25(57 \%)$ \\
Hypertension & $38(51 \%)$ & $16(52 \%)$ & $22(50 \%)$ \\
Diabetes mellitus & $14(19 \%)$ & $8(26 \%)$ & $6(14 \%)$ \\
Vascular disease & $40(53 \%)$ & $14(45 \%)$ & $26(59 \%)$ \\
Smoking & $26(35 \%)$ & $12(39 \%)$ & $14(32 \%)$ \\
\hline
\end{tabular}

† Results are expressed as mean (SD) 


\section{Baseline characteristics}

The baseline characteristics of the patients included in the study are given in table 3.1. No differences were found in baseline characteristics among the different subgroups of stroke patients.

\section{Pre-stroke blood pressure measurements}

Figure 3.1 shows the cumulative percentage of patients who had had blood pressure measurements in each six-month period before the stroke. About $90 \%$ of the patients had had at least one blood pressure measurement within 2 years prior to the stroke. As shown in figure 3.2, about $50 \%$ of the patients had had blood pressure measurements during 5 or more six-month periods before the stroke.

Figure 3.3 and table $3.2 \mathrm{~A}$ show the blood pressure in the 5 years preceding the stroke. On the whole, blood pressure had remained relatively unchanged in the 5 years before the stroke, except for a small, non-significant increase in the year before the stroke. The trend in blood pressure change in the 5 years before the stroke is shown in table 3.2A. This trend did not differ significantly from zero. Also, we found no difference in this trend between patients with $\mathrm{LACl}$ and patients with TERRI. The results were the same for the last two years prior to the stroke.

We found no significant difference in blood pressure change before the stroke between $\mathrm{LACl}$ and TERRI patients.

\section{Post-stroke blood pressure measurements}

Table 3.2B and figure 3.3 show post-stroke blood pressure according to stroke subtype and measurement technique. The post-stroke ambulatory blood pressure values were lower than the post-stroke office measurements. The difference was $7-11 \mathrm{~mm} \mathrm{Hg}$ for SBP and $3-4 \mathrm{~mm}$ $\mathrm{Hg}$ for DBP.

\section{Comparison of pre- and post-stroke blood pressure measurements}

Post-stroke office blood pressure measurements did not differ significantly from pre-stroke office measurements in any 6-months period in the 5 years preceding the stroke. Because the change in pre-stroke blood pressure did not differ significantly from zero, we also compared post-stroke office blood pressure with the average pre-stroke blood pressure. We found no significant difference between post-stroke and average pre-stroke blood pressures. 


\section{Table 3.2}

A: Blood pressure values at the ten 6-month time periods preceding stroke (mean and trend), according to stroke subtype mean (SD)

\begin{tabular}{|c|c|c|c|c|c|c|c|}
\hline & $\mathrm{N}$ & SBP & & & DBP & & \\
\hline & & All & $\mathrm{LACl}$ & TERRI & All & $\mathrm{LACl}$ & TERRI \\
\hline 4.5- 5 years & 31 & $153(17)$ & $154(20)$ & 151 (15) & $87(8)$ & $88(9)$ & $86(8)$ \\
\hline 4- 4.5 years & 36 & 153 (17) & $154(20)$ & 152 915) & $87(8)$ & $88(9)$ & $86(8)$ \\
\hline 3.5- 4 years & 38 & 154 (18) & $156(21)$ & $153(15)$ & $87(8)$ & $88(8)$ & $86(8)$ \\
\hline 3- 3.5 years & 34 & 154 (18) & $155(21)$ & 153 (16) & $87(9)$ & $88(9)$ & $86(9)$ \\
\hline 2.5- 3 years & 36 & 155 (18) & $156(22)$ & 154 (16) & $87(9)$ & $88(9)$ & $86(9)$ \\
\hline $2-2.5$ years & 32 & 154 (27) & $158(24)$ & $152(29)$ & $88(10)$ & $89(10)$ & 87 (10) \\
\hline $1.5-2$ years & 40 & $156(21)$ & $160(25)$ & 155 (18) & $88(9)$ & 89 (10) & 87 (8) \\
\hline $1-1.5$ years & 36 & $158(20)$ & $160(23)$ & 157 (18) & 87 (11) & 90 (10) & 85 (11) \\
\hline $0.5-1$ years & 37 & $158(20)$ & $163(23)$ & 155 (18) & 87 (12) & 91 (10) & 85 (12) \\
\hline $0-0.5$ years & 40 & 159 (23) & $164(27)$ & 155 (19) & 89 (11) & 93 (11) & $85(9)$ \\
\hline $\begin{array}{l}\text { change per } \\
\text { year }\end{array}$ & & 0.1 & 0.3 & -0.02 & 0.01 & 0.2 & -0.1 \\
\hline
\end{tabular}

B: Blood pressure values after stroke, according to stroke subtype and measurement technique mean (SD)

\begin{tabular}{lllllll}
\hline \multicolumn{5}{c}{ SBP } & & DBP \\
\hline & All & LACI & TERRI & All & LACI & TERRI \\
office & $155(23)^{\star}$ & $156(24)^{\star}$ & $154(22)^{\star}$ & $89(16)^{\star}$ & $93(18)^{\star}$ & $87(15)$ \\
ambulatory & $146(18)$ & $149(15)$ & $143(20)$ & $86(11)$ & $89(8)$ & $84(12)$ \\
\hline
\end{tabular}

* Significant difference compared to ambulatory blood pressure level 
Figure 3.1: Cumulative percentage of patients having blood pressure measurements at the ten half- year time periods in the five years preceding stroke

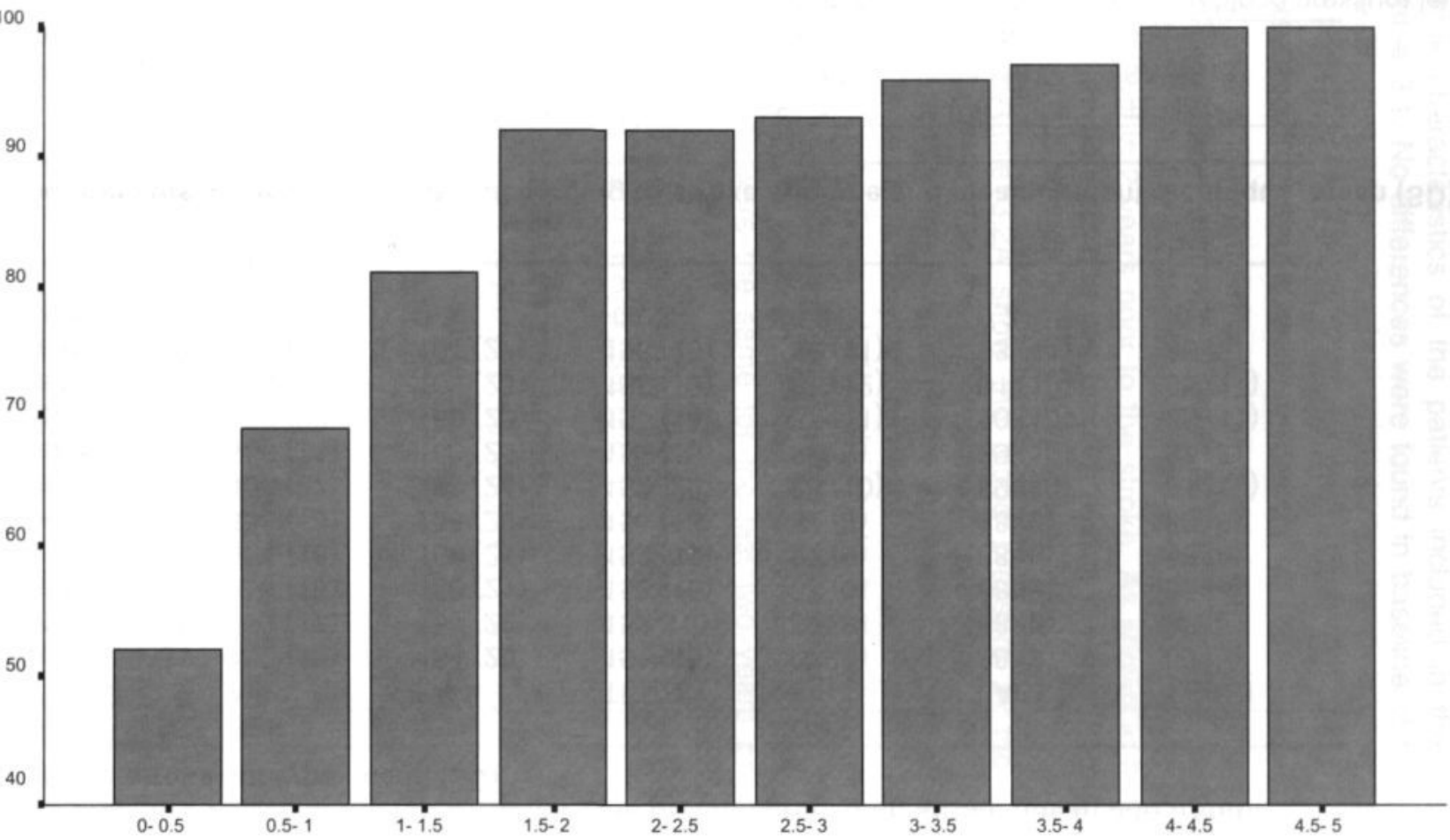


Figure 3.2: Cumulative percentage of patients and number of pre- stroke blood pressure measurements

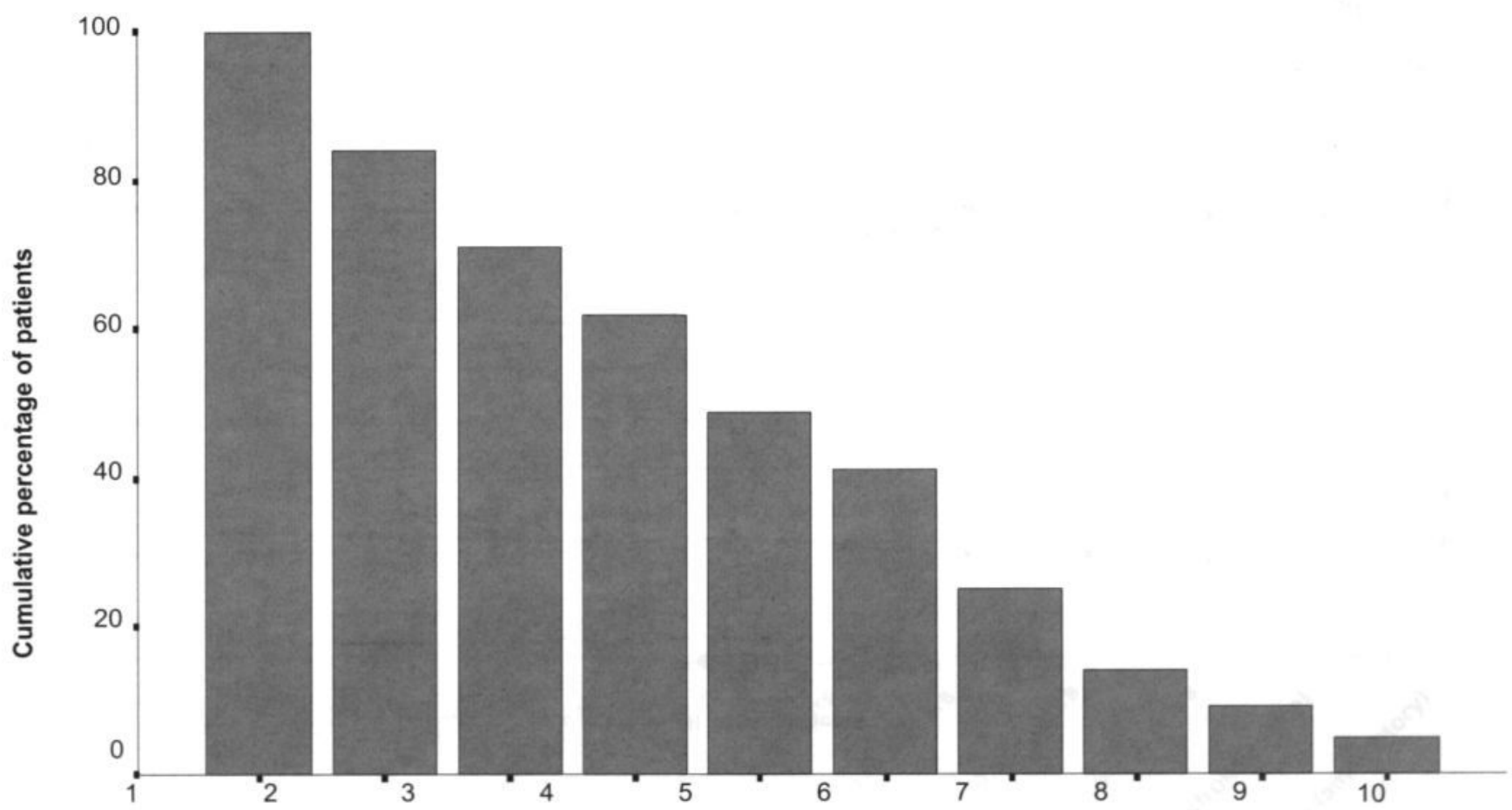

Number of pre- stroke blood pressure measurements 
Figure 3.3: SBP and DBP level $(\mathrm{mm} \mathrm{Hg})$ after stroke, and at ten different six- month time periods preceding

a. All infarct patients

$\bullet$ DBP $\multimap$ SBP

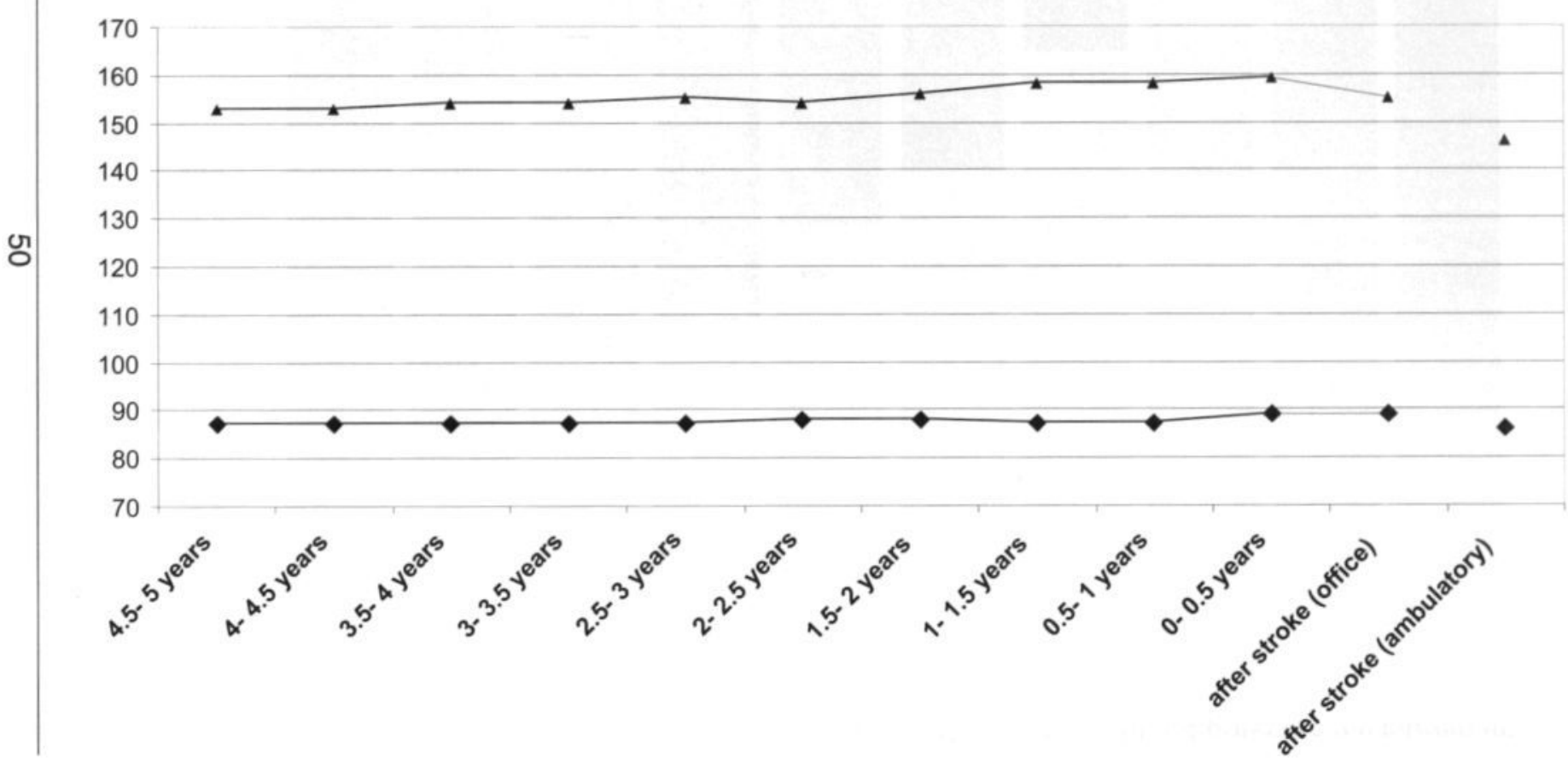




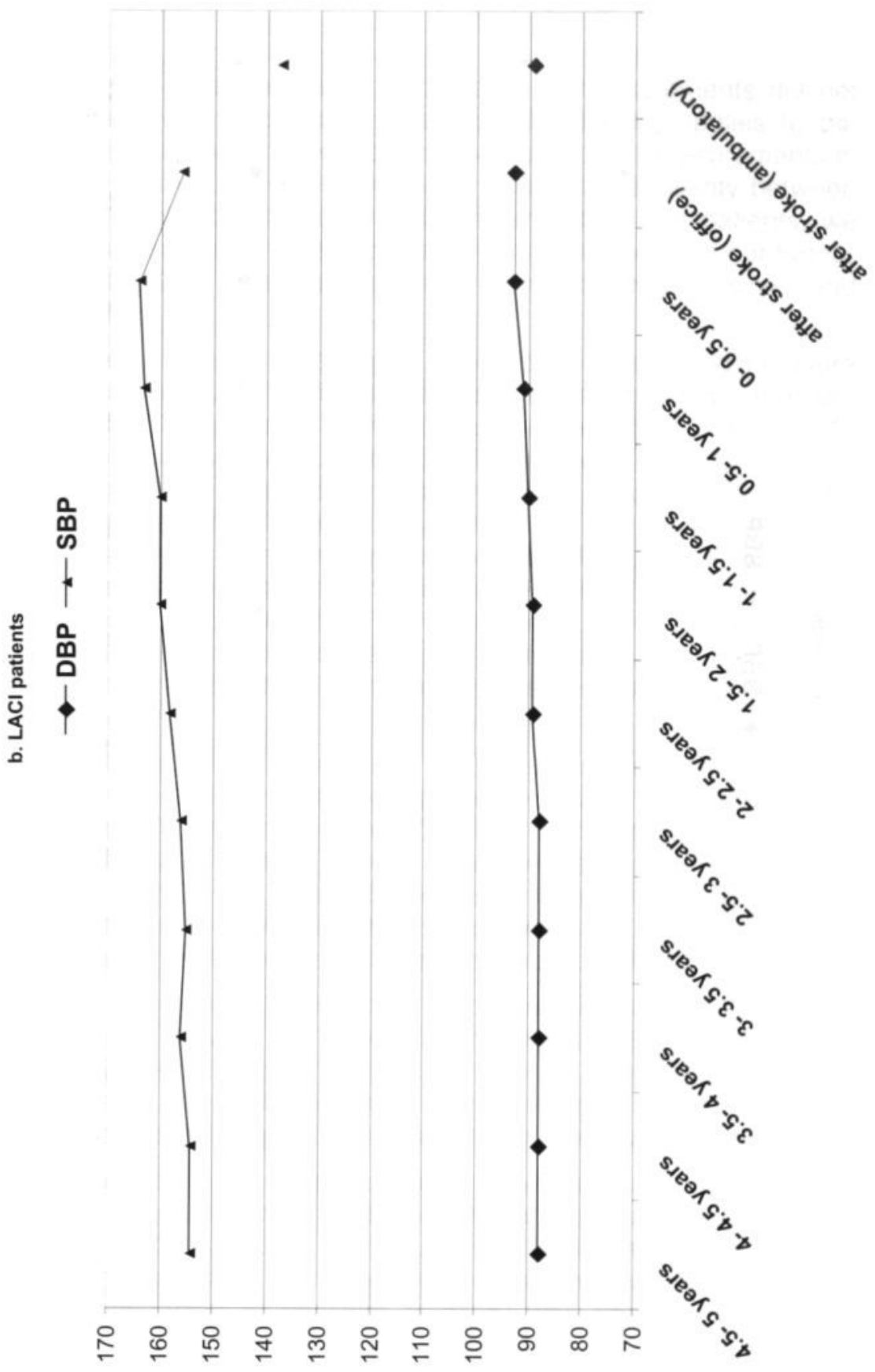




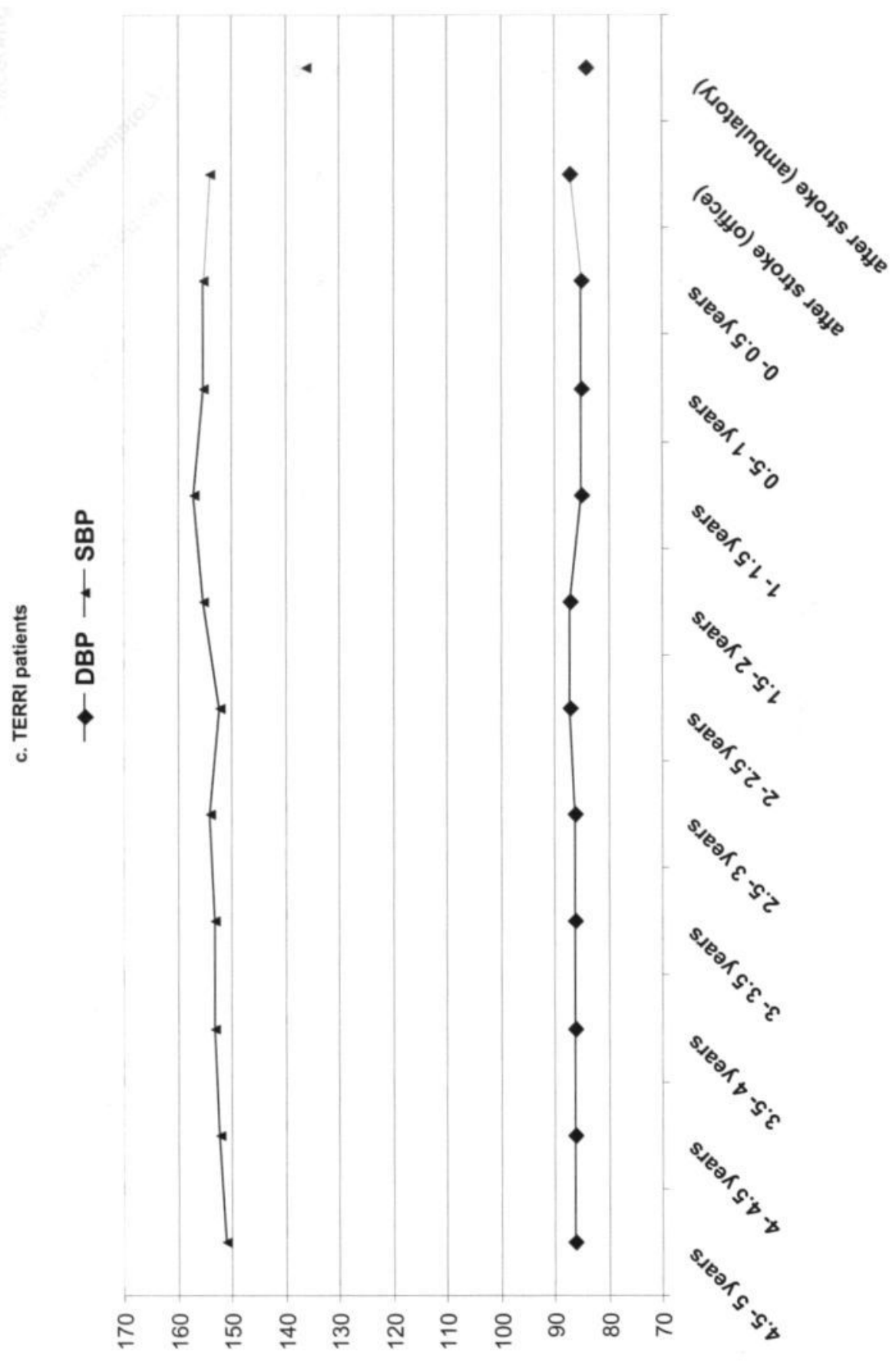




\section{DISCUSSION}

We found that post-stroke office blood pressure measurements did not differ from pre-stroke office measurements. This finding applies to the mean pre-stroke pressure as well as to blood pressure measurements in any 6-months period before the stroke. In view of the similarity between pre- and post-stroke blood pressure measurements in our patients, we decided it was reasonable to use post-stroke measurements in our further studies investigating the relationship between hypertension and ischaemic stroke.

We are aware of one other study in which pre-stroke blood pressure values were compared with post-stroke measurements, using a mercury manometer, in 178 patients with TIA and cerebral infarction [127]. Contrary to our study, the authors found that mean pre-stroke blood pressure was higher than post-stroke pressure. However, pre-stroke measurements were available in only $78(44 \%)$ of the 178 patients. Moreover, post-stroke measurements were available in only 48 patients, so a comparison between pre- and post-stroke blood pressure values could only be made in $48(27 \%)$ of the patients. Selection bias may therefore have played a role in this part of their study. Also, the authors gave no information about the number of pre-stroke measurements the patients had had.

After an extensive search we found that three-quarters of our stroke patients had had one or more blood pressure measurements recorded within 5 years prior to the stroke. Of these patients, $90 \%$ had had measurements taken within 2 years prior to the stroke. Twenty-five percent of our patients had had no blood pressure measurements within 5 years prior to the stroke. We think it is preferable to use post-stroke blood pressure measurements, because these are always available.

Only 39 patients in our study had had blood pressure measurements in the last 6 months prior to the stroke. At this time (1993 - 1996), many general practitioners changed from paper records to computer records. This may have affected the way they recorded blood pressure measurements. The blood pressure measured in these patients was high.

For pre-stroke blood pressure measurements, we had to rely on records kept by general practitioners and hospital records. Unavoidably, this resulted in a wide variation in the amount of information that was available. This may have led to selection bias towards patients with a history of hypertension or vascular disease, who visit their physician regularly. This bias may explain the fact that those patients in our study 
who did have blood pressure measurements in the last year before the stroke had high blood pressure.

Little is known about the blood pressure course prior to stroke. We found that the course of blood pressure in the 5 years preceding the stroke was rather stable in our patients. The trend of a small increase in blood pressure in the year preceding the stroke was not statistically significant. We found no difference in blood pressure change between patients with $\mathrm{LACl}$ and patients with TERRI. Post-stroke ambulatory and post-stroke office blood pressures differed significantly between the two infarct subgroups.

We found that post-stroke ambulatory blood pressure values were significantly lower than post-stroke office measurements. These findings are in line with findings in the literature, which reports that average daytime blood pressure, as measured by an ambulatory measuring device, is $7-10 \mathrm{~mm} \mathrm{Hg}$ lower than blood pressure measured using mercury manometry $[12,13,14,15,16]$. The reason for this is probably that the multiple measurements taken by the ambulatory device provide a better estimate of mean blood pressure. Furthermore, office measurements may be higher than ambulatory measurements because of the alerting reaction known as isolated office hypertension $(\mathrm{IOH})$. 


\section{Chapter 4: DO AMBULATORY BLOOD PRESSURE} MEASUREMENTS IN THE ACUTE PHASE OF STROKE PREDICT
BLOOD PRESSURE IN THE CHRONIC PHASE OF STROKE?

Abstract

Objective: Treatment of hypertension reduces the risk of (recurrent) stroke. Nevertheless, the question remains whether blood pressure measurements obtained in the acute phase after stroke may be used to assess whether a patient is truly hypertensive or not. We therefore investigated whether blood pressure measurements in the acute phase after stroke predict those in the chronic phase.

Design and Methods: One hundred stroke patients were included in the present study. MRI and CT scans were used to define stroke subtype (i.e. lacunar or territorial). Blood pressures were obtained by 24-hour ambulatory monitoring at about 1 week (acute phase) and about 6 weeks (chronic phase) after stroke. To assess whether the blood pressure profile in the acute phase of stroke predicts that in the chronic phase, we performed linear regression analysis and calculated correlation coefficients and prediction intervals for each infarct group.

Results: Although correlations were found between blood pressure levels in the acute and chronic phase of stroke, prediction intervals were wide. Blood pressure variability and diurnal rhythm in the acute phase of stroke correlated moderately with those in the chronic phase, with the best correlation for blood pressure variability in patients with a lacunar infarct.

Conclusions: For a given level of blood pressure as measured in the acute phase of stroke, we were unable to predict whether a patient's blood pressure in the chronic phase would fall in the normotensive or the hypertensive range. Blood pressure measurements one week after stroke are unsuitable to assess the blood pressure profile in the chronic phase. 


\section{INTRODUCTION}

In a previous study, we found that post-stroke office blood pressure measurements in the chronic phase (about 6 weeks after the stroke) reliably reflected pre-stroke blood pressure data (chapter 3 ). In the first days after a stroke, a rise in blood pressure $[58,126,127,128,129,131$, 132]. Blood pressure declines spontaneously in the first week after the stroke. It would be advantageous if acute blood pressure measurements could be used to assess whether a stroke patient has hypertension, instead of waiting several weeks for the chronic measurements. However, it is still uncertain whether these acute measurements can be used to assess whether the patient has hypertension.

We therefore investigated whether ambulatory blood pressure measurements in the acute phase of stroke reflect those in the chronic phase by measuring 24-hour ambulatory blood pressure profiles in stroke patients during the acute and chronic phases.

\section{PATIENTS AND METHODS}

Patients and methods have been extensively described in chapter 2 .

The following analyses were performed:

1) Comparison of baseline characteristics (Mann-Whitney, chisquared test).

2) To assess whether the blood pressure characteristics in the acute phase of stroke predict those in the chronic phase (linear regression analysis)

3) To investigate whether intra-individual differences in blood pressure between the acute and chronic phases after the stroke were related to blood pressure level (scatterplots).

\section{RESULTS}

Of the 100 stroke patients who entered the study, 81 underwent both CT and MRI scanning, while 19 patients only underwent CT scanning. Since, as described in chapter 2, CT and MRI diagnoses were in good agreement, we used all patients in the subsequent analysis.

Ninety-four patients $(94 \%)$ had an infarct, while 6 patients $(6 \%)$ had an intracerebral haemorrhage. Of the infarct patients, $38(40 \%)$ had a 
lacunar infarct (LACI), while $56(60 \%)$ had a territorial infarct (TERRI). Because the number of patients with cerebral haemorrhage was too small to be included in the analysis, we used the infarct patients for the subsequent analysis.

The scatterplots showed no relationship between intra-individual differences in blood pressure between the acute and chronic phases after the stroke on the one hand and the blood pressure level on the other.

\section{Baseline characteristics}

The baseline characteristics of the 94 infarct patients are shown in table 4.1.

Table 4.1: Baseline characteristics in the 94 brain infarct patients

\begin{tabular}{|c|c|}
\hline Characteristics & $\begin{array}{l}\text { Infarct patients } \\
\mathrm{n}=94 \\
\mathrm{~N}(\%)\end{array}$ \\
\hline $\mathrm{Age}^{\dagger}$ & $65(13)$ \\
\hline Male gender & $53(56 \%)$ \\
\hline Hypertension & $42(45 \%)$ \\
\hline Diabetes Mellitus & $18(19 \%)$ \\
\hline Vascular disease & $43(46 \%)$ \\
\hline Smoking & $36(38 \%)$ \\
\hline
\end{tabular}

$\dagger$ Results are expressed as mean (SD)

\section{Ambulatory blood pressure measurements in the acute and chronic phases}

Table 4.2 shows the mean blood pressure levels, nocturnal dip and percentage of dipping and median variability of blood pressure for the study group. Nocturnal blood pressure was raised in the acute phase of stroke, whereas daytime and 24-hour blood pressures in the acute and chronic phases were comparable. Dipping was blunted in the acute phase of stroke.

Table 4.3 shows the results of the linear regression analysis, giving correlation coefficients and prediction intervals. The correlation of blood pressure levels in the acute and chronic phases of the stroke was good in all three patient groups, though prediction intervals were wide. Correlation was lowest and prediction intervals were narrowest in patients with lacunar infarcts. Blood pressure variability and diurnal rhythm in the acute phase of the stroke correlated moderately with those in the chronic phase. Prediction intervals for nocturnal dip and percentage of dipping 
were wide. The correlation of blood pressure variability was best in patients with a lacunar infarct.

Table 4.2: Blood pressure characteristics in the acute and chronic phase of stroke according to stroke subtype

\begin{tabular}{llllllll}
\hline Patients & \multicolumn{3}{c}{$\begin{array}{l}\text { All infarct patients } \\
n=94\end{array}$} & \multicolumn{2}{l}{$\begin{array}{l}\text { TERRI } \\
n=56(60 \%)\end{array}$} & \multicolumn{2}{l}{$\begin{array}{l}\text { LACl } \\
n=38(40 \%)\end{array}$} \\
\hline blood pressure & $\begin{array}{l}\text { acute } \\
\text { phase }\end{array}$ & $\begin{array}{l}\text { chronic } \\
\text { phase }\end{array}$ & $\begin{array}{l}\text { acute } \\
\text { phase }\end{array}$ & $\begin{array}{l}\text { chronic } \\
\text { phase }\end{array}$ & $\begin{array}{l}\text { acute } \\
\text { phase }\end{array}$ & $\begin{array}{l}\text { chronic } \\
\text { phase }\end{array}$ \\
Level $^{\dagger}$ & & & & & & & \\
SBP & Daytime & 145 & 144 & 141 & 140 & 151 & 149 \\
& Nighttime & 147 & 133 & 143 & 132 & 152 & 136 \\
MBP & 24- hours & 142 & 142 & 139 & 138 & 145 & 147 \\
& Daytime & 105 & 104 & 102 & 101 & 110 & 109 \\
& Nighttime & 107 & 95 & 104 & 93 & 112 & 97 \\
DBP & 24- hours & 101 & 103 & 99 & 100 & 105 & 107 \\
& Daytime & 86 & 85 & 83 & 82 & 90 & 89 \\
& Nighttime & 87 & 75 & 84 & 74 & 92 & 78 \\
& 24- hours & 81 & 83 & 79 & 81 & 85 & 87
\end{tabular}

Variability ${ }^{\ddagger}$

$\begin{array}{llllllll}\text { SBP } & \text { Daytime } & 13 & 15 & 13 & 16 & 14 & 15 \\ & \text { Nighttime } & 13 & 11 & 12 & 11 & 14 & 10 \\ & \text { 24-hours } & 9 & 17 & 9 & 17 & 10 & 17 \\ \text { MBP } & \text { Daytime } & 13 & 13 & 13 & 13 & 14 & 13 \\ & \text { Nighttime } & 13 & 10 & 12 & 10 & 14 & 10 \\ & \text { 24-hours } & 10 & 14 & 10 & 14 & 10 & 14 \\ \text { DBP } & \text { Daytime } & 16 & 14 & 16 & 14 & 16 & 14 \\ & \text { Nighttime } & 14 & 9 & 14 & 9 & 14 & 9 \\ & \text { 24-hours } & 12 & 14 & 12 & 14 & 13 & 14\end{array}$

Dip $^{\dagger}$

$\begin{array}{lllllll}\text { SBP } & 6 & 11 & 5 & 11 & 7 & 12 \\ \text { MBP } & 6 & 11 & 4 & 10 & 7 & 11 \\ \text { DBP } & 5 & 10 & 4 & 10 & 7 & 11\end{array}$

Percentage of dipping ${ }^{\dagger}$

\begin{tabular}{lllllll} 
SBP & 6 & 8 & 6 & 7 & 8 & 8 \\
MBP & 5 & 10 & 4 & 10 & 6 & 11 \\
DBP & 4 & 12 & 3 & 11 & 5 & 13 \\
\hline
\end{tabular}

† Mean

$\ddagger$ Median 
Table 4.3: Correlation and $95 \%$ prediction intervals at the mean of the blood pressure characteristics in the acute and chronic phase of stroke according to stroke subtype

\begin{tabular}{|c|c|c|c|c|c|c|c|}
\hline Patien & & $\begin{array}{l}\text { All ir } \\
n=9\end{array}$ & ret patients & $\begin{array}{l}\text { TER } \\
n=5\end{array}$ & $60 \%)$ & $\begin{array}{l}\text { LAC } \\
n=3\end{array}$ & $(40 \%)$ \\
\hline Blood & sure & CC & $\mathrm{PI}$ & CC & PI & CC & PI \\
\hline Level & & & & & & & \\
\hline SBP & Daytime & 0.8 & $119-176$ & 0.8 & $111-186$ & 0.7 & $130-169$ \\
\hline & Nigh & 0.8 & 100 & 0.8 & 95- & 0.7 & $118-161$ \\
\hline & 24- hc & 0.7 & $77-169$ & 0.7 & 64- 164 & 0.7 & $127-169$ \\
\hline MBP & Daytin & 0.7 & $87-131$ & 0.7 & $81-122$ & 0.6 & $97-125$ \\
\hline & Nightti & 0.7 & $71-121$ & 0.8 & $66-128$ & 0.6 & $88-114$ \\
\hline & 24- hours & 0.7 & 74- 129 & 0.8 & $67-128$ & 0.7 & $95-125$ \\
\hline DBP & Daytime & 0.7 & $71-109$ & 0.7 & $66-96$ & 0.6 & 79- 104 \\
\hline & Nighttime & 0.7 & 57- 102 & 0.8 & 51- 104 & 0.6 & $72-94$ \\
\hline & 24- hours & 0.7 & $66-110$ & 0.8 & $62-113$ & 0.7 & $77-105$ \\
\hline
\end{tabular}

Variability

$\begin{array}{llllllll}\text { SBP } & \text { Daytime } & 0.5 & 11-24 & 0.6 & 11-26 & 0.4 & 14-21 \\ & \text { Nighttime } & 0.3 & 10-25 & 0.4 & 10-27 & 0.3 & 10-17 \\ & 24-\text { hours } & 0.2 & 13-22 & 0.1 & 13-21 & 0.4 & 14-23 \\ \text { MBP } & \text { Daytime } & 0.2 & 9-16 & 0.1 & 9-16 & 0.5 & 11-18 \\ & \text { Nighttime } & 0.2 & 8-16 & 0.2 & 9-17 & 0.3 & 8-15 \\ & 24-\text { hours } & 0.5 & 10-20 & 0.6 & 10-20 & 0.4 & 12-17 \\ \text { DBP } & \text { Daytime } & 0.6 & 10-20 & 0.6 & 10-21 & 0.6 & 10-18 \\ & \text { Nighttime } & 0.1 & 9-12 & 0.1 & 9-13 & 0.1 & 9-11 \\ & \text { 24- hours } & 0.003 & 14-29 & 0.04 & 14-16 & 0.5 & 12-18\end{array}$

Dip

$\begin{array}{lllllll}\text { SBP } & 0.5 & -3-29 & 0.4 & -4-24 & 0.5 & 2-29 \\ \text { MBP } & 0.5 & -2-22 & 0.5 & -2-19 & 0.6 & -0.3-25 \\ \text { DBP } & 0.5 & -0.3-25 & 0.5 & -1-17 & 0.5 & 1-30\end{array}$

Percentage of dipping

\begin{tabular}{lllllll} 
SBP & 0.5 & $-2-21$ & 0.5 & $-2-22$ & 0.5 & $0.7-21$ \\
MBP & 0.5 & $-2-21$ & 0.5 & $-2-18$ & 0.6 & $-2-23$ \\
DBP & 0.5 & $-2-27$ & 0.5 & $-2-22$ & 0.6 & $0-31$ \\
\hline
\end{tabular}

$\mathrm{CC}-$ Correlation Coefficient $\mathrm{PI}-$ Prediction Interval 


\section{Diagnosing hypertension in the acute and chronic phase after stroke}

Table 4.4A shows the number of patients that were classified as normotensive and hypertensive in the acute and in the chronic phase after stroke (As discussed in chapter 1, patients with SBP $>I=140 \mathrm{~mm} \mathrm{Hg}$ and/or DBP $>1=90 \mathrm{~mm} \mathrm{Hg}$ were considered hypertensive). Table 4.4B shows the number of patients that remain in the same category, that is, the number of patients classified as hypertensive in the acute phase who are, again, classified as hypertensive in the chronic phase, and the number of normotensive patients in the acute phase who remain normotensive.

More patients were considered to be hypertensive in the acute phase than in the chronic phase. Fifteen percent of the normotensive patients and $20 \%$ of the hypertensive patients did not remain in the same category in the chronic phase after stroke.

Table 4.4: Classification in the acute and chronic phases after stroke

A: Number of normotensive and hypertensive patients in the acute and chronic phases after stroke.

\begin{tabular}{lll}
\hline & Acute phase & Chronic phase \\
\hline Normotensive & 39 & 44 \\
Hypertensive & 55 & 50 \\
\hline
\end{tabular}

B: Number of patients remaining in the same category

\begin{tabular}{lll}
\hline & $\begin{array}{l}\text { Category in the acute } \\
\text { phase }\end{array}$ & $\begin{array}{l}\text { Remaining in this } \\
\text { category in the } \\
\text { chronic phase }\end{array}$ \\
\hline $\begin{array}{l}\text { Normotensive } \\
\text { hypertensive }\end{array}$ & 39 & 33 \\
\hline
\end{tabular}

Patients with SBP $>/=140 \mathrm{~mm} \mathrm{Hg}$ and/or DBP $>/=90 \mathrm{~mm} \mathrm{Hg}$ were considered hypertensive 


\section{Discussion}

We found that blood pressure levels in the acute phase of a stroke correlated well with those in the chronic phase in all three infarct groups. Blood pressure variability, dip and percentage of dipping were less closely correlated than blood pressure levels. Correlation of blood pressure variability in the acute and chronic phases of stroke was best in patients with lacunar infarcts. Classification of patients as hypertensive or normotensive showed that more patients were considered to be hypertensive in the acute phase than in the chronic phase after stroke. Also, $15-20 \%$ of patients did not remain in the same category.

Earlier studies of the natural course of blood pressure after stroke have used mercury manometers and 24-hour ambulatory blood pressure measurements $[58,90,126,127,128,129,131,132]$. A rise in blood pressure was found to occur in the acute phase, while blood pressure tended to decline over the next ten days. In the chronic phase of stroke, raised blood pressure may occur. This may be a result of the stroke, or it may be a sign of previously undiagnosed hypertension [125, 127, 128]. In our study, we found that nighttime blood pressure was lower in the chronic phase than in the acute phase, whereas daytime blood pressure was comparable. This indicates an acute rise in nighttime blood pressure measured 6 days after the stroke. In most previous studies, blood pressure was found to have declined at this time.

As discussed in chapter 1, hypertension is an important risk factor for ischaemic stroke. Treatment of hypertension reduces this risk, especially in individuals who have additional vascular risk factors due to other disorders such as diabetes. This risk reduction is achieved within a few years of starting treatment. Therefore, it is clearly advantageous if stroke patients who have hypertension are treated as soon as possible after their stroke. Similarly, treatment for hypertension newly discovered after the stroke should be started promptly. This may prevent recurrent stroke and other complications. However, the assessment of a patient's blood pressure profile should be made at a time when the changes occurring in the acute phase of stroke have plateaued, and a status quo has been reached. This is important to avoid treating patients who have no sustained hypertension.

So the question remains whether blood pressure characteristics measured one week after the stroke reflect those in the chronic phase. Assessing blood pressure profile and starting treatment for hypertension may easily be done when patients are still hospitalised. Our results indicate moderate to good agreement between blood pressure characteristics one week and six weeks after the stroke. However, the 
prediction intervals were wide. Moreover, $20 \%$ of patients classified as hypertensive in the acute phase of stroke were no longer hypertensive in the chronic phase. This means that for a given blood pressure level measured in the acute phase of the stroke, we were not able to predict whether the value measured in the chronic phase would be classified as hypertensive or normotensive.

Blood pressure measurement one week after a stroke therefore seems unsuitable to diagnose hypertension in the chronic phase. We found an acute rise in nighttime blood pressure persisting 6 days after the stroke. 


\title{
Chapter 5: SeVerity of hypertension AS A DETERMINANT OF THE TYPE OF STROKE: IMPACT OF DAYTIME VERSUS NIGHTTIME PRESSURE
}

\begin{abstract}
Objective: Hypertension is an important risk factor for brain infarcts in general, but the question whether hypertension predisposes to one particular subtype of brain infarcts (i.e. lacunar or teritorial) remains controversial. The aim of the present study, therefore, was to compare blood pressure levels in patients with lacunar infarcts ( $\mathrm{LACl})$ to those in patients with territorial infarcts (TERRI). Since it has been reported that nighttime blood pressure is more closely related to target organ damage (TOD) than daytime blood pressure, we studied blood pressure levels both during daytime and during nighttime. Results were compared to blood pressure levels in controls. We also compared patients with LACI to patients with TERRI.
\end{abstract}

Design and Methods: One hundred stroke patients and a control group of 131 healthy volunteers from the same geographical region participated in the study. MRI and CT scans were used to define stroke subtype. Blood pressure was measured by 24-hour ambulatory monitoring. In the patients, this was done about 6 weeks after stroke.

Results: Brain infarct patients had higher blood pressure compared to controls. This was also true when the LACl and TERRI subgroups were analysed separately. Although an equal proportion of patients with LACI and TERRI reported to have had hypertension prior to the stroke, the actual blood pressure level was higher in patients with LACI than in patients with TERRI. After multivariate logistic regression analysis, differences between TERRI and LACI on the one hand and controls on the other were most pronounced for nighttime blood pressure.

Conclusions: Not the presence of hypertension itself, but rather its severity may be a determinant of brain infarct subtype. Increased blood pressure levels, especially during nighttime, is associated with brain infarcts in general. 


\section{INTRODUCTION}

Hypertension is an important risk factor for ischaemic and haemorrhagic stroke $[1,2,4,16,50,51]$. Stroke comprises a heterogeneous group of disorders, including brain infarction with various subgroups such as lacunar ( $\mathrm{LACl}$ ) and territorial (TERRI) infarcts, and haemorrhagic stroke such as primary intracerebral haemorrhage. The significance of blood pressure as a risk factor for stroke may differ between the various stroke subgroups. Hypertension has been regarded as a significant risk factor especially for lacunar infarction $[19,20,21,22,149,150]$ but several studies have shown that the prevalence of hypertension did not differ between lacunar infarct patients and territorial infarct patients $[8,25,151$, $152,153,154,155]$.

Studies of the relationship between blood pressure and stroke have often used single or repeated office blood pressure measurements, which do not always reliably reflect the true blood pressure (see chapter 1). Ambulatory blood pressure measurement using a portable 24-hour measuring device is an accurate and non-invasive method to study an individual's blood pressure. Multivariate blood pressure measurements closely related in time can be obtained during the daytime as well as during the night. Furthermore, individuals may be studied while performing normal daily activities. The values obtained are closely related to target organ damage (TOD) and mortality. Interference by so-called isolated office hypertension $(\mathrm{IOH})$, or 'white coat hypertension', and bias due to regression to the mean are avoided $[15,17,18,88,89]$. Ambulatory blood pressure measurements have scarcely been performed in stroke patients, especially compared to healthy volunteers.

We aimed to study the relationship between blood pressure level and ischaemic stroke subtypes. Because of the advantages of ambulatory blood pressure measurement, we investigated blood pressure level with 24-hour ambulatory monitoring in patients with various stroke subtypes and a control group of healthy volunteers. We were especially interested to see whether the level of blood pressure determined the subtype of brain infarct. 


\section{PATIENTS AND METHODS}

Patients and methods have been extensively described in chapter 2.

The following analyses were performed:

1) Baseline characteristics (Mann Whitney test, chi squared test)

2) Comparison of blood pressure level in controls and stroke patients ( $T$ - test). Because age is an independent risk factor influencing blood pressure level, we selected the 90 oldest controls and 90 youngest brain infarct patients to obtain groups that were matched for age.

3) Investigating the relationship between blood pressure level and brain infarction (Multivariate logistic regression analysis)

\section{RESULTS}

Of the 100 stroke patients who entered the study, 81 underwent both CT and MRI scanning, while 19 patients underwent only CT scanning. As described in chapter 2, we used CT results in patients for whom MRI was not available, because CT and MRI diagnoses were in good agreement.

Ninety-four patients $(94 \%)$ had a brain infarct, while 6 patients $(6 \%)$ had an intracerebral haemorrhage. Of the infarct patients, $38(40 \%)$ had a $\mathrm{LACl}$ and $56(60 \%)$ a TERRI. Because the number of patients with cerebral haemorrhage was too small to be included in the analysis, we only included the infarct patients in the subsequent analysis. We compared infarct patients with controls and TERRI patients with LACI patients.

\section{Baseline characteristics}

The baseline characteristics of our study population are shown in table 5.1. Results are presented as mean (SD) or number (percentage) of individuals. Patients are classified according to infarct subtype. The controls reported significantly less hypertension, diabetes and vascular disease than the total group of infarct patients. The vascular risk factor profile was similar in the lacunar and territorial infarct patients. In particular, the percentage of patients reporting a history of hypertension did not differ. 
Table 5.1: Baseline characteristics in age- matched controls and brain infarct patients

\begin{tabular}{lllll}
\hline Characteristics & Controls & Infarct patients & TERRI & LACl \\
& $n=90$ & $n=90$ & $n=54$ & $n=36$ \\
& $\mathrm{~N}(\%)$ & $\mathrm{N}(\%)$ & $\mathrm{N}(\%)$ & $\mathrm{N}(\%)$ \\
\hline Age $^{\dagger}$ & $62(11)$ & $64(12)$ & $66(13)$ & $65(12)$ \\
Male gender & $57(63 \%)$ & $53(59 \%)$ & $32(57 \%)$ & $21(55 \%)$ \\
Hypertension & $21(23 \%)$ & $39(43 \%)^{*}$ & $24(43 \%)^{*}$ & $18(47 \%)^{*}$ \\
Diabetes Mellitus & $4(4 \%)$ & $17(19 \%)^{*}$ & $8(14 \%)^{*}$ & $10(26 \%)^{*}$ \\
Vascular disease & $16(18 \%)$ & $42(47 \%)^{*}$ & $27(48 \%)^{*}$ & $16(42 \%)^{\star}$ \\
Smoking & $24(27 \%)$ & $36(40 \%)$ & $21(38 \%)$ & $15(40 \%)$ \\
\hline
\end{tabular}

$\dagger$ Results are expressed as mean (SD)

* Significant difference between patient- and control group.

\section{Ambulatory blood pressure measurements in brain infarct patients compared to controls}

Table 5.2 shows blood pressure levels in controls and infarct patients. The infarct patients had significantly higher blood pressure values than the controls during the daytime as well as the nighttime and over 24 hours. The lacunar and territorial infarct subgroups also had higher blood pressure than the controls.

Multivariate logistic regression analysis shows that these differences were significant, except for daytime SBP and MBP in the total group of infarct patients (figure $5.1 \mathrm{~A}$ ), and in the subgroup of TERRI patients.

Table 5.2: Blood pressure level in controls and stroke patients (mean)

\begin{tabular}{|c|c|c|c|c|c|}
\hline blood & $\mathrm{re}(\mathrm{mm} \mathrm{Hg})$ & \multirow{2}{*}{$\begin{array}{l}\begin{array}{l}\text { Controls } \\
n=90\end{array} \\
129\end{array}$} & \multirow{2}{*}{$\begin{array}{l}\text { Infarct } \\
\text { patients } \\
n=90^{\circ} \\
143^{\star}\end{array}$} & \multirow{2}{*}{$\begin{array}{l}\text { TERRI } \\
n=56 \\
(60 \%) \\
140^{*}\end{array}$} & \multirow{2}{*}{$\begin{array}{l}\text { LACI } \\
n=38 \\
(40 \%) \\
149^{\star \star \star}\end{array}$} \\
\hline SBP & Daytime & & & & \\
\hline & Nighttime & 115 & $133^{\star}$ & 132 * & 136 * \\
\hline & 24- hour & 126 & $141^{\star}$ & $138^{*}$ & $147^{\star \star \star}$ \\
\hline \multirow[t]{3}{*}{ MBP } & Daytime & 97 & $104^{*}$ & $101^{*}$ & $109 * * *$ \\
\hline & Nighttime & 84 & $94^{*}$ & $93^{*}$ & $97^{*}$ \\
\hline & 24- hour & 94 & $102^{*}$ & 100 * & $107^{\star \star \star *}$ \\
\hline \multirow[t]{3}{*}{ DBP } & Daytime & 81 & $84^{*}$ & $82^{*}$ & $89^{\star \star \star}$ \\
\hline & Nighttime & 67 & $75^{\star}$ & $74^{*}$ & $78^{*}$ \\
\hline & 24- hour & 77 & $83^{\star}$ & $81^{\star}$ & $87^{* * *}$ \\
\hline
\end{tabular}

* Significant difference compared to controls

** Significant difference compared to territorial infarcts 
Ambulatory blood pressure measurements in LACI patients compared to TERRI patients

Patients with lacunar infarcts had significantly higher blood pressure than patients with territorial infarcts, except for nighttime blood pressure. After multivariate logistic regression analysis, 24-hour blood pressure was higher in LACl patients than in TERRI patients (figure 5.1B). 
Figure 5.1: Relationship between blood pressure level and stroke and infarct subtype; aOR and $95 \% \mathrm{Cl}$ for 1st vs 2nd blood pressure tertile (hair line), and 1st vs. 3rd blood pressure tertile (bold line).

A: Brain infarcts in general compared to controls

SBP

daytime

nighttime

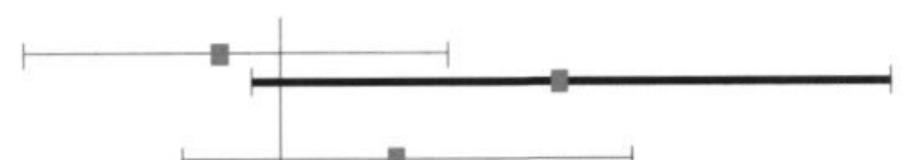

ஜ

24 hours

MBP

daytime

nighttime

24 hours

DBP

daytime

nighttime

24 hours

i

4

4. 5

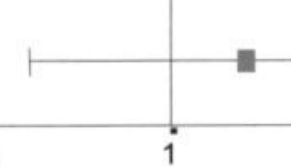

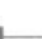
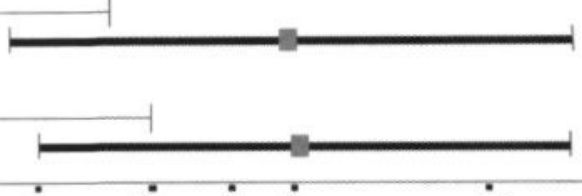

10

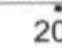


B: LACI compared to TERRI

daytime

nighttime

MBP

daytime

nighttime

24 hours

DBP

daytime

nighttime

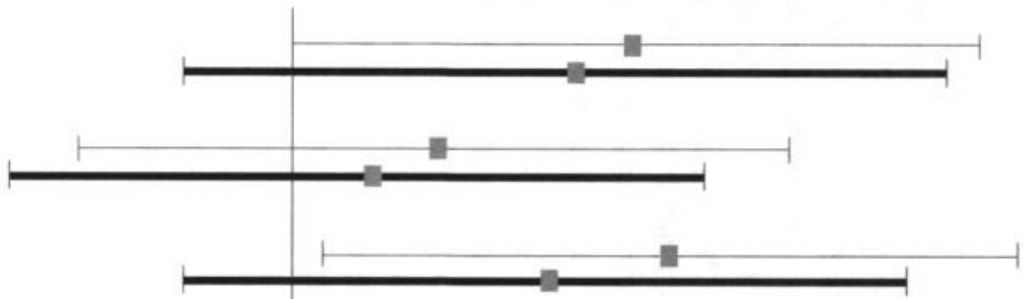

24 hours

$\begin{array}{llll}\dot{2} & . \dot{3} & . & .\end{array}$
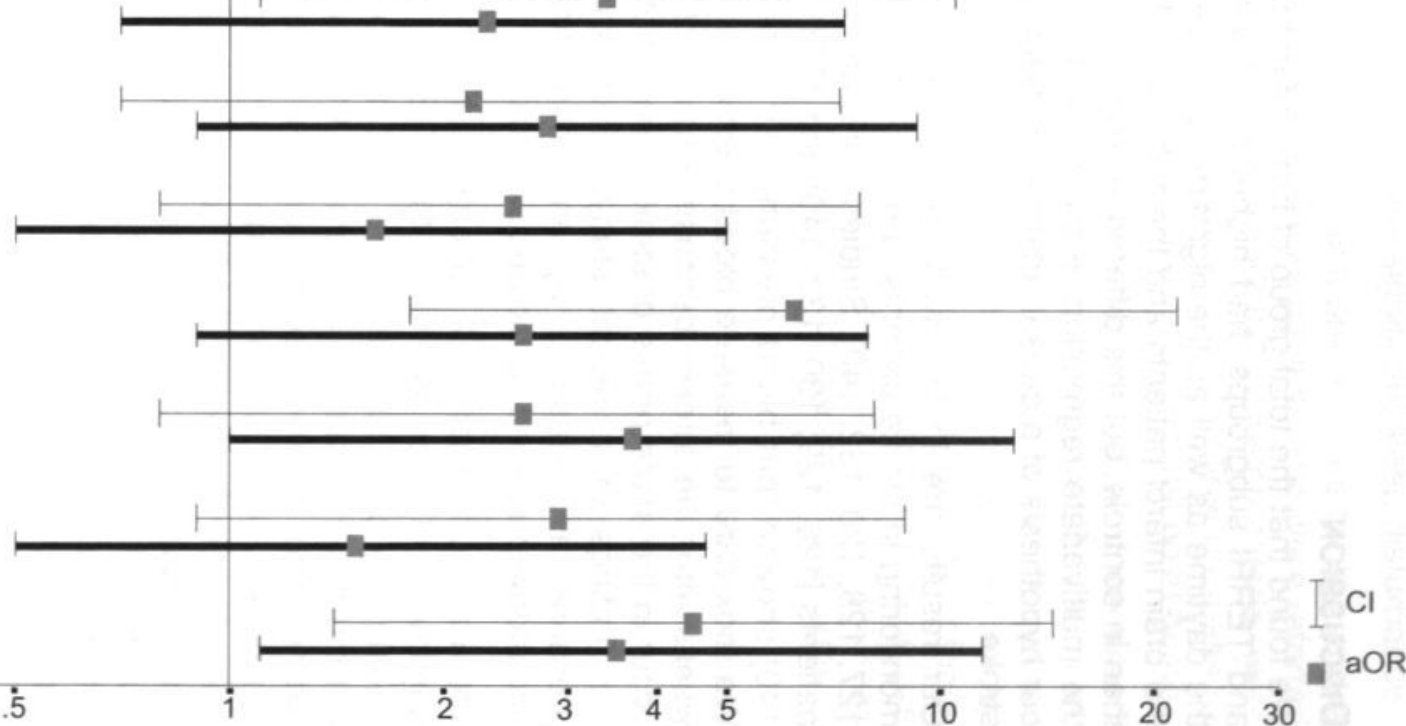


\section{Discussion}

We found that the total group of brain infarct patients, as well as the LACI and TERRI subgroups, had higher blood pressure than controls, during the daytime as well as the nighttime and over 24 hours. Daytime SBP in the brain infarct patients and the subgroup of TERRI patients was higher than in controls, but this difference did not reach statistical significance in the multivariate regression analysis which was performed to investigate our hypothesis of a causal relationship between blood pressure level and stroke.

Our results are in line with most previous studies of blood pressure monitoring in stroke patients in general compared to controls [17, 27, 58, $127,128,129,132,140]$. Studies using ambulatory measurement in LACl patients $[126,129,130,132,140]$ and TERRI patients $[27,91,129,132$, 140 ] showed that blood pressure was raised in both infarct subgroups. We took care to measure blood pressure in the chronic phase (about 6 weeks after the stroke) because a transient rise in blood pressure may occur in the acute phase of stroke (see chapter 4). Our data also confirm the findings of a recent study, which showed that nighttime blood pressure, as measured by an ambulatory measuring device, more accurately predicted cardiovascular risk than daytime pressure [75].

We also found that $\mathrm{LACl}$ patients had higher SBP and DBP during the daytime and over 24 hours than TERRI patients. Hypertension has traditionally been regarded as a specific risk factor for lacunar infarction, but more recent studies have shown that the prevalence of hypertension did not differ between lacunar and territorial infarct patients [25, 156]. In our patient group, the prevalence of hypertension in the medical history was also similar for the LACI and TERRI patients. However, the LACI patients had significantly higher SBP and DBP than the TERRI patients. Our results therefore suggest that it is not hypertension in itself that determines the subtype of brain infarct, but rather the severity of hypertension.

In our study, we performed 24-hour ambulatory blood pressure measurement about 6 weeks after the stroke. In chapter 3 we showed that it is reasonable to assume that post-stroke office blood pressure measurements reliably reflect pre-stroke blood pressure. Because of several important advantages, we preferred ambulatory blood pressure measurements to office measurements. The blood pressure measurement was almost always performed at home as patients had usually been discharged from the hospital by this time. All patients had already undergone acute or subacute ambulatory blood pressure 
measurement while in hospital. This second measurement was not experienced as stressful, and did not cause significant sleep disturbance.

The Maastricht University hospital serves as a primary care facility, and is the only hospital in the referral area. All stroke patients who were referred to the hospital were screened, and if they met the inclusion criteria, were asked to participate in the study. To reduce loss to follow-up, patients who were unable or unwilling to return for follow-up were visited at home.

Our study found that the percentage of $\mathrm{LACl}$ patients $(40 \%$ of the infarct patients) was higher than expected from the literature $[24,26,116,146$, $147,152]$. Patients with a severe neurological deficit or decreased consciousness (often associated with TERRI) were more likely to be excluded from our study because of their severe neurological symptoms. Furthermore, we included patients visiting the outpatient clinic, who are likely to have milder symptoms (often associated with LACI). This may have led to selection bias towards patients with moderate clinical signs of stroke, and thus towards patients with LACl.

In conclusion we found that increased blood pressure levels, especially during the nighttime, were associated with brain infarcts in general as a sign of TOD. Furthermore, it is apparently not the hypertension itself, but its severity which determines the brain infarct subtype. 
Chapter 5 


\title{
CHAPTER 6A: BLOOD PRESSURE VARIABILITY AND STROKE: BLOOD PRESSURE VARIABILITY IN RELATION TO STROKE SUBTYPE
}

\begin{abstract}
Objective: Blood pressure variability and either an extreme or a blunted nocturnal blood pressure decline (nocturnal dipping) are potential risk factors in patients sustaining a stroke. In chapter 5 we found that the severity of hypertension determines brain infarct subtype. However, it is unknown whether other aspects of the 24-hour blood pressure profile, especially during the night, also determine brain infarct subtype. Therefore, we studied 24-hour blood pressure variability in brain infarct patients and controls. We also compared patients with lacunar infarcts (LACI) to patients with territorial infarcts (TERRI).
\end{abstract}

Design and Methods: One hundred stroke patients and a control group of 131 healthy volunteers from the same geographical region participated in the study. MRI and CT scans were used to define stroke subtype. Blood pressure was measured by 24 -hour ambulatory monitoring. For patients, this was done about 6 weeks after stroke.

Results: Brain infarct patients in general and the LACI and TERRI subgroups in particular had greater blood pressure variability and a blunted circadian rhythm compared to controls. We found no difference in blood pressure variability and circadian rhythm between patients with $\mathrm{LACl}$ and patients with TERRI.

Conclusions: Increased blood pressure variability, especially during nighttime and a blunted diurnal rhythm are associated with brain infarcts in general as a sign of target organ damage. The diurnal blood pressure profile does not determine brain infarct subtype. 


\section{INTRODUCTION}

Hypertension is an important vascular risk factor [1, 2, 4, 16, 50, 51]. Vascular risk is associated not only with blood pressure level, but also with non-dipping (absence or blunting of the physiological blood pressure decline during the night), extreme nocturnal dipping and blood pressure variability $[12,16,59,60,61,62,63,64]$. Nocturnal dipping and blood pressure variability can be assessed using ambulatory blood pressure measurement $[15,17,18,88,89,90]$. In the present study, we wanted to investigate whether extreme or blunted nocturnal dipping and blood pressure variability are also risk factors for the development of brain infarcts. We therefore evaluated aspects of diurnal blood pressure change and blood pressure variability in patients with brain infarcts compared with controls using 24-hour ambulatory blood pressure measurements. We also compared patients with lacunar infarcts (LACI) with patients with territorial infarcts (TERRI). We had previously found that LACI patients had higher SBP and DBP than TERRI patients (chapter 5). We therefore wanted to investigate whether they also differed with regard to variability and diurnal rhythm.

\section{PATIENTS AND METHODS}

Patients and methods have been extensively described in chapter 2 .

The following analyses were performed:

1) Baseline characteristics (Mann Whitney test, chi squared test)

2) Comparison of blood pressure variability, nocturnal dip and percentage of dipping in controls and stroke patients (T- test). Because age is an independent risk factor influencing blood pressure level, we selected the 90 oldest controls and 90 youngest brain infarct patients to obtain groups that were matched for age.

3) Investigating the relationship between blood pressure variability, nocturnal dip and percentage of dipping and brain infarction (Multivariate logistic regression analysis)

4) To compare the relationship between blood pressure variability and blood pressure level as well as nocturnal dip and the percentage of dipping (scatterplots). 


\section{RESULTS}

Of the 100 stroke patients who entered the study, 81 underwent both CT and MRI scanning, while 19 patients underwent only CT scanning. As described in chapter 2, we included all patients in the subsequent analysis, because CT and MRI diagnosis were in good agreement.

Ninety-four patients (94\%) had an infarct, while 6 patients $(6 \%)$ had an intracerebral haemorrhage. Of the infarct patients, $38(40 \%)$ had a lacunar infarct and $56(60 \%)$ a territorial infarct (TERRI). Because the number of patients with cerebral haemorrhage was too small, we only included the infarct patients in the subsequent analysis. We compared infarct patients with controls and TERRI patients with LACI patients.

The baseline characteristics of our study population are described in chapter 5.

\section{Ambulatory blood pressure measurements in brain infarct patients compared to controls}

Table 6.1 shows blood pressure variability, dip and percentage of dipping of blood pressure in the controls and infarct patients. Results are presented as median standard deviation and mean nocturnal dip and percentage of dipping. The infarct patients had higher blood pressure variability during the daytime and over 24 hours, a decreased nocturnal dip and a decreased percentage of dipping compared to the controls. With regard to the subgroups of TERRI and $\mathrm{LACl}$ patients, the results were similar but, due to the rather small number of patients, the differences were not always statistically significant. Significant differences were not explained by the relationship between blood pressure variability and blood pressure level. Multivariate logistic regression analysis showed that the infarct patients in general (figure 6.1) and the subgroup of TERRI patients had higher blood pressure variability and a decreased nocturnal dip and percentage of dipping compared to controls. In contrast, LACI patients only had a higher 24-hour SBP variability, a decreased nocturnal MBP dip and a decreased MBP and DBP percentage of dipping compared to controls.

\section{Ambulatory blood pressure measurements in LACl patients compared to TERRI patients}

Blood pressure variability and nocturnal dip and percentage of dipping did not differ between the LACI and TERRI patients (table 6.1). Multivariate logistic regression analysis showed that variability tended to be higher and nocturnal dip tended to be lower in LACI patients than in TERRI 
patients (figure 6.2). These differences were not significant, except for a higher nighttime SBP variability in LACI patients.

Table 6.1: Blood pressure variability (expressed as SD), nocturnal dip and Percentage of dipping in controls and stroke patients

\begin{tabular}{|c|c|c|c|c|c|}
\hline \multicolumn{2}{|c|}{$\begin{array}{l}\text { Blood pressure } \\
\text { characteristics }\end{array}$} & $\begin{array}{l}\text { Controls } \\
n=90\end{array}$ & $\begin{array}{l}\text { Infarct } \\
\text { patients } \\
\mathrm{n}=90\end{array}$ & $\begin{array}{l}\text { TERRI } \\
n=56 \\
(60 \%)\end{array}$ & $\begin{array}{l}\text { LACI } \\
n=38 \\
(40 \%)\end{array}$ \\
\hline \multicolumn{6}{|c|}{ Variability (SD) ${ }^{\ddagger}$ : } \\
\hline \multirow[t]{3}{*}{ SBP } & Daytime & 12 & $15^{*}$ & $16^{*}$ & $15^{*}$ \\
\hline & Nighttime & 10 & 10 & 11 & 10 \\
\hline & 24- hour & 14 & $17^{*}$ & $17^{*}$ & $17^{*}$ \\
\hline \multirow[t]{3}{*}{ MBP } & Daytime & 11 & $13^{*}$ & $13^{*}$ & $13^{*}$ \\
\hline & Nighttime & 8 & 10 & 10 & 10 \\
\hline & 24-hour & 12 & $14^{*}$ & 14 & $14^{*}$ \\
\hline \multirow[t]{3}{*}{ DBP } & Daytime & 12 & $14^{*}$ & 14 & $14^{\star}$ \\
\hline & Nighttime & 8 & 9 & 9 & 9 \\
\hline & 24- hour & 13 & $14^{*}$ & 14 & 14 \\
\hline \multicolumn{6}{|c|}{ Dip $\left(\mathrm{mm} \mathrm{Hg}^{\dagger}\right.$ : } \\
\hline \multicolumn{2}{|l|}{ SBP } & 14 & 11 & 11 & 12 \\
\hline \multicolumn{2}{|l|}{ MBP } & 13 & 11 & 10 & 11 \\
\hline \multicolumn{2}{|l|}{ DBP } & 14 & $10^{*}$ & $10^{*}$ & 11 \\
\hline \multicolumn{6}{|c|}{ Percentage of dipping $(\%)^{\dagger}$ : } \\
\hline \multicolumn{2}{|l|}{ SBP } & 11 & $8^{*}$ & 7 & 8 \\
\hline \multicolumn{2}{|l|}{ MBP } & 14 & $10^{*}$ & $10^{*}$ & 11 \\
\hline \multicolumn{2}{|l|}{ DBP } & 17 & $12^{*}$ & $11^{*}$ & $13^{*}$ \\
\hline
\end{tabular}

$\dagger$ Mean

$\ddagger$ Median

* Significant difference compared to controls 
Figure 6.1: Relationship between variability, dip and Percentage of dipping of blood pressure and brain infarcts in general; aOR and $95 \% \mathrm{Cl}$ for 1 st vs 2 nd blood pressure tertile (hair line), and 1st vs. 3rd blood pressure tertile (bold line).

\section{A: Variability}

SBP

daytime

nighttime

24 hours

MBP

daytime

nighttime

24 hours

DBP

daytime

nighttime

24 hours

04
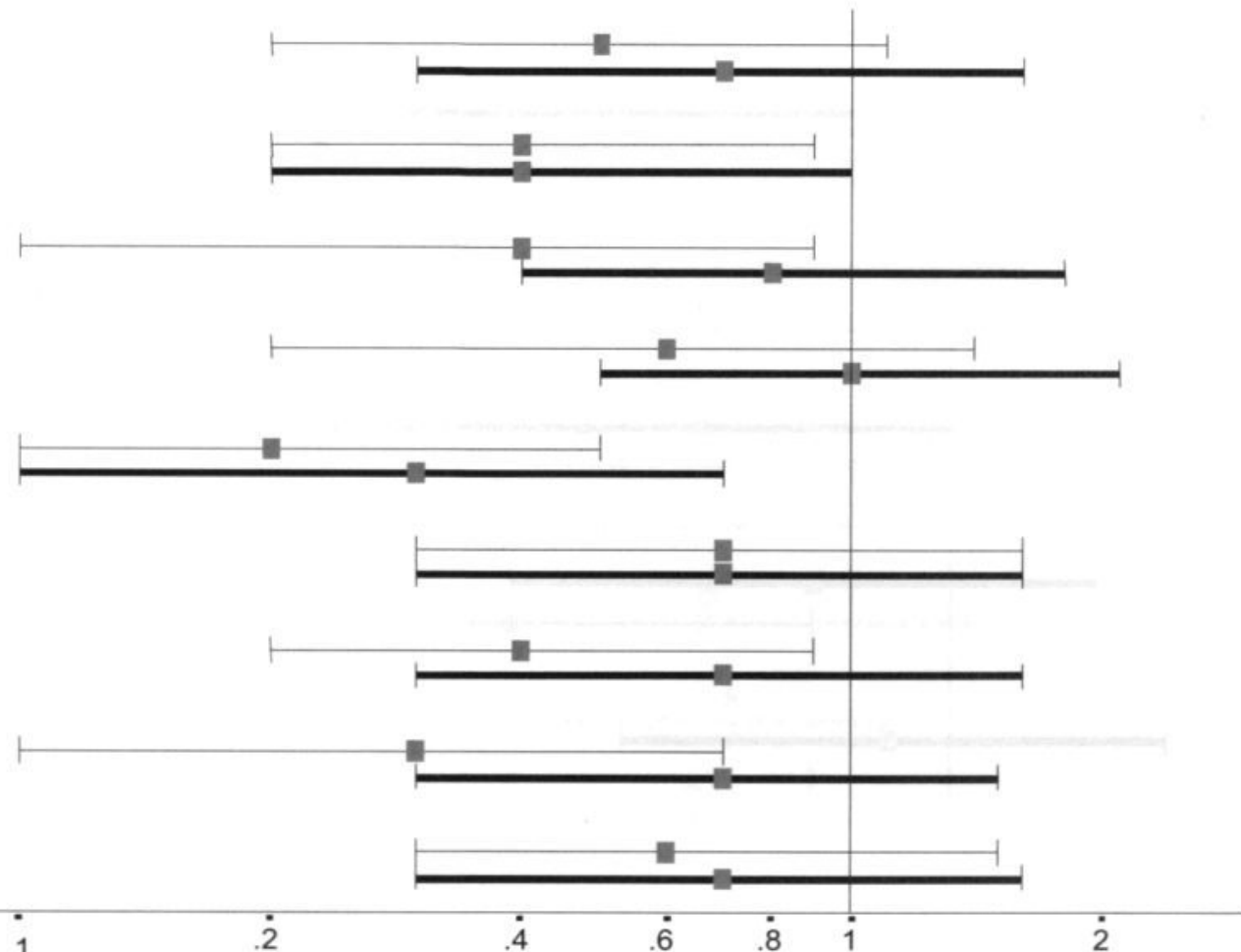
B: Nocturnal dip an Percentage of dipping

Dip

SBP

MBP

DBP

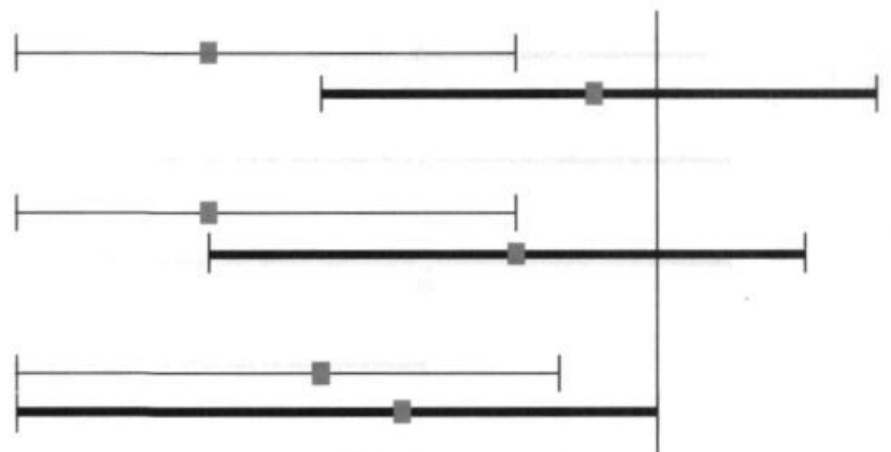

$\infty$

Percentage of dipping

SBP

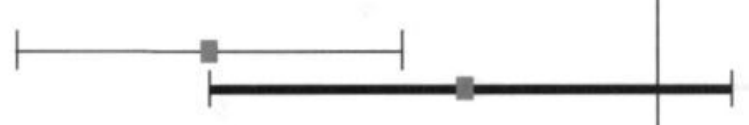

MBP

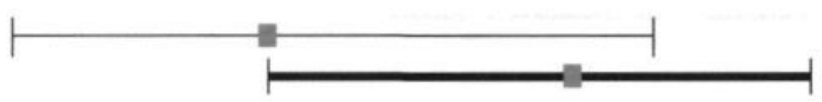

DBP

01

.03

05

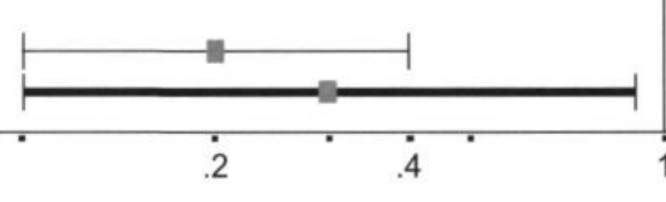


Figure 6.2: Relationship between variability, dip and Percentage of dipping of blood pressure and infarct subtype (LACl compared to TERRI) I; aOR and $95 \% \mathrm{Cl}$ for 1st vs 2nd blood pressure tertile (hair line), and 1st vs. 3rd blood pressure tertile (bold line).

A: Variability

\section{SBP}

daytime

nighttime

24 hours

MBP

daytime

nighttime

24 hours

\section{DBP}

daytime

nighttime

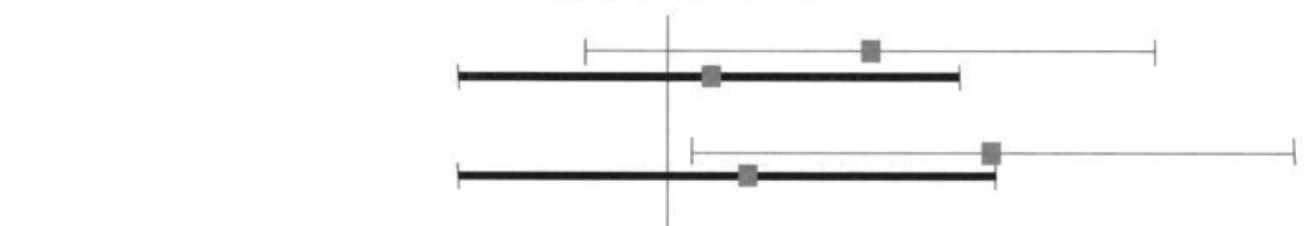

24 hours

02

.04 
B: Nocturnal dip and percentage of dipping

Dip

SBP

MBP

๕ัด

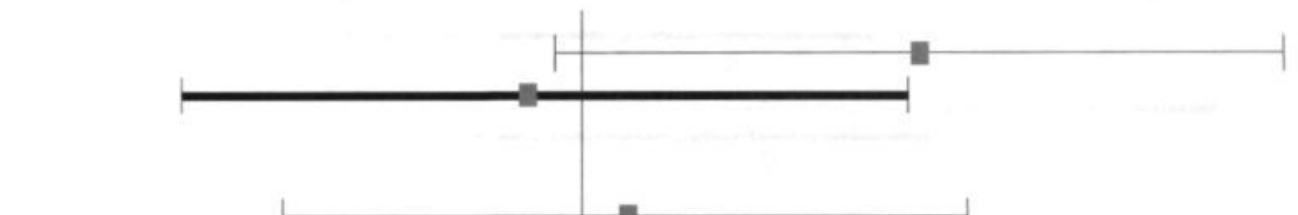

DBP

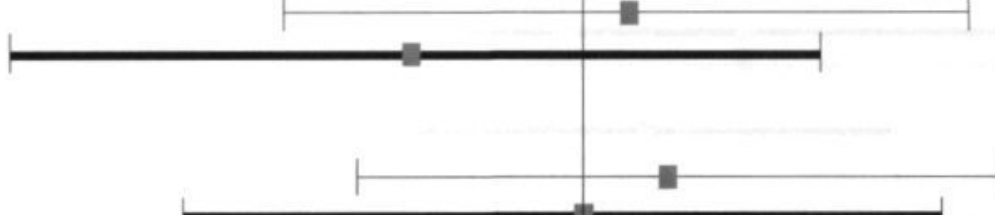

Percentage of dipping

SBP

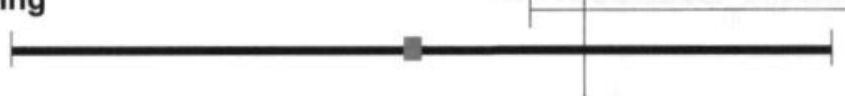

MBP

DBP

$03 \quad .05$ 


\section{Discussion}

We found that the brain infarct patients had a higher daytime and 24-hour blood pressure variability and a decreased nocturnal dip and percentage of dipping compared to controls. Our results support the assumption that variability and diurnal rhythm of blood pressure are associated with the development of brain infarcts, as a sign of TOD.

Increased blood pressure variability has been associated with target organ damage (TOD) in general and with (silent or symptomatic) brain infarct in particular $[12,16,17,59,60,62,63,64,130,140]$. In these studies, stroke patients generally had increased blood pressure variability and a reduced nocturnal dip and percentage of dipping [27, 60]. However, these studies described patients in the acute phase of stroke, when a temporary blunting of the nocturnal dip may occur due to the stroke itself (see chapter 4). In our study, we took care to perform blood pressure measurement in the chronic phase (about 6 weeks after the stroke). At this time, any changes in blood pressure profile that may be attributable to the occurrence of the stroke are expected to have levelled off in most patients (see chapter 2).

Earlier studies showed that differences in aspects of diurnal blood pressure rhythm and blood pressure variability between controls and TERRI patients were more striking than those found comparing controls with LACI patients [27, 32, 130, 140]. We also found that nocturnal dip and percentage of dipping differed more clearly between TERRI patients and controls than between LACI patients and controls. This suggests either that nocturnal dip is more closely related to the development of TERRI than to the development of LACI, or that TERRI results in blunting of the nocturnal pressure decline. To further explore this question, we studied the relationship between blood pressure variability, dip and percentage of dipping and infarct subtype.

We found no significant differences in blood pressure variability, nocturnal dip or percentage of dipping between the LACI and TERRI groups. This agrees with an earlier study, which also failed to demonstrate significant differences in variability, nocturnal dip or percentage of dipping between TERRI patients and LACI patients, although the dip and percentage of dipping of SBP tended to be higher in LACI patients.

In conclusion, we found that increased blood pressure variability, especially during the nighttime, and decreased nocturnal dip and percentage of dipping are associated with brain infarcts in general as a sign of TOD. These aspects of the blood pressure profile do not determine the brain infarct subtype. 


\title{
CHAPTER 6B: BLOOD PRESSURE VARIABILITY AND STROKE: THE LEVEL OF BLOOD PRESSURE AND ITS VARIABILITY IN RELATION TO THE TYPE OF LACUNAR STROKE
}

\begin{abstract}
Objective: Recently, it has been hypothesised that there are two clinically distinct lacunar infarct ( $\mathrm{LACl}$ ) entities, which may be caused by two different types of small vessel disease: microatheromatosis and arteriolosclerosis respectively. Previous studies found that patients with multiple LACls more often had hypertension than those with a single LACI, indicating that blood pressure may play a role in determining the type of lacunar stroke. In the present study, we investigated whether the 24-hour blood pressure profile could paly a role as a determinant of the type of lacunar stroke. To this end, we compared blood pressure profiles in patients with multiple LACls to those in patients with a single LACI. We also compared these patients with patients with territorial infarcts (TERRI), the latter being caused by large vessel atheromatosis.
\end{abstract}

Design and Methods: One hundred stroke patients participated in the study. MRI and CT scans were used to define stroke subtype. Blood pressure was assessed by 24-hour ambulatory monitoring, about 6 weeks after stroke.

Results: We found that patients with multiple LACls had higher blood pressure level than patients with single LACI and patients with TERRI. Variability of SBP was greater in patients with multiple LACls than in patients with TERRI. The blood pressure profile of patients with single $\mathrm{LACl}$ was comparable to that of patients with TERRI.

Conclusions: These results support the theory that brain infarcts based upon arteriolosclerosis and those caused by microatheromatosis are characterized by different blood pressure profiles and, therefore, may constitute, different clinical entities. 


\section{INTRODUCTION}

Recently, the existence of two clinically distinct lacunar infarct (LACI) entities was hypothesised, one involving multiple LACls on brain imaging and one involving a single $\mathrm{LACl}[26]$. This hypothesis was based on the existence of two pathologically defined subgroups of small vessel disease $[19,20,21,22,149,150]$, which, according to this hypothesis, also manifest themselves clinically as two distinct lacunar stroke entities. Furthermore, it was hypothesised that lacunar stroke patients with multiple LACIs presumably have arteriolosclerosis or lipohyalinosis, while lacunar stroke patients with a single $\mathrm{LACl}$ presumably have microatheromatosis [26].

The question is what determines whether a patient develops multiple LACls or just a single LACI. Previous studies found that patients with multiple LACls more often had hypertension than those with a single LACI $[23,26]$. So, blood pressure may play a role in determining the type of lacunar stroke.

In the present study, we investigated whether blood pressure level, variability and aspects of diurnal rhythm determined the type of lacunar stroke, using 24-hour ambulatory measurements in patients with lacunar stroke. We compared patients with multiple LACls and patients with a single LACI. Furthermore, these patients were compared with patients with territorial infarcts (TERRI).

\section{PATIENTS AND METHODS}

Patients and methods have been extensively described in chapter 2 .

The following analyses were performed:

1) Baseline characteristics (Mann Whitney test, chi squared test)

2) Comparison of blood pressure level, blood pressure variability and nocturnal dip in patients with single $\mathrm{LACl}$ and patients with multiple LACls (T- test).

3) Investigating the relationship between blood pressure level blood pressure variability and nocturnal dip and lacunar infarct subtype (Multivariate logistic regression analysis). 


\section{RESULTS}

As described in chapter 2, we used all patients in the subsequent analysis because CT and MRI diagnosis were in good agreement,.

Of the 94 infarct patients, $38(40 \%)$ had a LACI and $56(60 \%)$ a TERRI. Of the LACI patients, $14(37 \%)$ had a single LACI, while $24(63 \%)$ had multiple LACls on MRI. We compared patients with multiple LACls with those with a single $\mathrm{LACl}$ and TERRI patients with those with multiple and single LACls.

\section{Baseline characteristics}

The baseline characteristics of our study population are shown in table 6.2. Results are presented as mean (SD) or number (percentage) of individuals. Patients are classified according to infarct subtype. The risk factor profile did not show significant differences between the infarct subgroups.

Table 6.2 Baseline characteristics according to infarct subtype

\begin{tabular}{llll}
\hline Characteristics & TERRI & $\begin{array}{l}\text { Single LACI } \\
n=56\end{array}$ & $\begin{array}{l}\text { Multiple LACI } \\
\mathrm{n}=5(37 \%)\end{array}$ \\
& $\mathrm{N}(\%)$ & $\mathrm{N}(\%)$ & $\mathrm{N}(\%)$ \\
\hline Age $^{\dagger}$ & $66(13)$ & $64(15)$ & $65(10)$ \\
Male gender & $32(57 \%)$ & $8(57 \%)$ & $13(54 \%)$ \\
Hypertension & $24(43 \%)$ & $6(43 \%)$ & $12(50 \%)$ \\
Diabetes Mellitus & $8(14 \%)$ & $4(29 \%)$ & $6(25 \%)$ \\
Vascular disease & $27(48 \%)$ & $4(29 \%)$ & $12(50 \%)$ \\
Smoking & $21(38 \%)$ & $5(36 \%)$ & $10(42 \%)$ \\
\hline
\end{tabular}

† Results are expressed as mean (SD)

\section{Comparison of single and multiple LACIs.}

Patients with multiple LACls had significantly higher SBP and MBP than those with a single LACI (table 6.3). DBP also tended to be higher in patients with multiple LACls, but this difference did not reach statistical significance. Furthermore, SBP variability and nighttime DBP and MBP variability were significantly higher than in patients with a single $\mathrm{LACl}$. Dipping and percentage of dipping did not differ between these groups.

The multivariate logistic regression analysis showed that patients with multiple LACls had significantly higher 24-hour MBP and DBP and nighttime DBP than patients with a single LACI (figure 6.3). Moreover, 24- 
hour variability of SBP was also significantly higher in patients with multiple LACIs.

Table 6.3: Blood pressure level, variability (expressed as SD), nocturnal dip and Percentage of dipping according to infarct subtype

\begin{tabular}{|c|c|c|c|c|}
\hline \multicolumn{2}{|c|}{$\begin{array}{l}\text { Blood } \\
\text { pressure }\end{array}$} & $\begin{array}{l}\text { TERRI } \\
n=56(60 \%)\end{array}$ & $\begin{array}{l}\text { Single LACI (14) } \\
\mathrm{n}=14(37 \%)\end{array}$ & $\begin{array}{l}\text { Multiple LACI } \\
n=24(63 \%)\end{array}$ \\
\hline \multicolumn{5}{|c|}{ Level $^{\dagger}$} \\
\hline \multirow[t]{3}{*}{ SBP } & Daytime & 144 & 139 & $155^{* \star \star}$ \\
\hline & Nighttime & 133 & 127 & $141^{* \star \star *}$ \\
\hline & 24- hour & 142 & 138 & $151^{\star \star \star \star}$ \\
\hline \multirow[t]{3}{*}{ MBP } & Daytime & 104 & 103 & $113^{* \star \star}$ \\
\hline & Nighttime & 95 & 91 & $101^{* * *}$ \\
\hline & 24-hour & 103 & 101 & $109^{* \star *}$ \\
\hline \multirow[t]{3}{*}{ DBP } & Daytime & 85 & 85 & $91^{\star \star}$ \\
\hline & Nighttime & 75 & 73 & $80^{* *}$ \\
\hline & 24-hour & 83 & 83 & $88^{* *}$ \\
\hline \multicolumn{5}{|c|}{ Variability ${ }^{\ddagger}$} \\
\hline \multirow[t]{3}{*}{ SBP } & Daytime & 16 & $13^{* \star}$ & $16^{*}$ \\
\hline & Nighttime & 11 & $10^{\star \star}$ & $13^{\star}$ \\
\hline & 24-hour & 17 & 13 & $18^{*}$ \\
\hline \multirow[t]{3}{*}{ MBP } & Daytime & 13 & 13 & 13 \\
\hline & Nighttime & 10 & 7 & $10^{*}$ \\
\hline & 24-hour & 14 & 14 & 15 \\
\hline \multirow[t]{3}{*}{ DBP } & Daytime & 14 & 13 & 14 \\
\hline & Nighttime & 9 & 8 & $12^{*}$ \\
\hline & 24-hour & 14 & 14 & 14 \\
\hline \multicolumn{5}{|l|}{$\operatorname{Dip}^{\dagger}$} \\
\hline \multicolumn{2}{|l|}{ SBP } & 11 & 14 & 10 \\
\hline \multicolumn{2}{|l|}{ MBP } & 10 & 13 & 10 \\
\hline \multicolumn{2}{|l|}{ DBP } & 10 & 13 & 10 \\
\hline \multicolumn{5}{|c|}{ Percentage of dipping ${ }^{\dagger}$} \\
\hline & 7 & 10 & 7 \\
\hline \multicolumn{2}{|l|}{ MBP } & 10 & 12 & 9 \\
\hline \multicolumn{2}{|l|}{ DBP } & 11 & 15 & 12 \\
\hline
\end{tabular}

$\dagger$ Mean

$\ddagger$ Median

* Significant difference compared to single LACI

** Significant difference compared to TERRI 
Figure 6.3: Relationship between blood pressure level, variability and circadian rhythm and infarct subtype (Multiple LACl compared to single LACI); $\mathrm{Cl}$ and aOR for 1st vs 2nd tertile and 1st vs 3rd tertile.

\section{Blood pressure level}

SBP

daytime

nighttime

24 hours

MBP

daytime

四

nighttime

24 hours

DBP

daytime

nighttime

24 hours

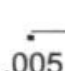

.005

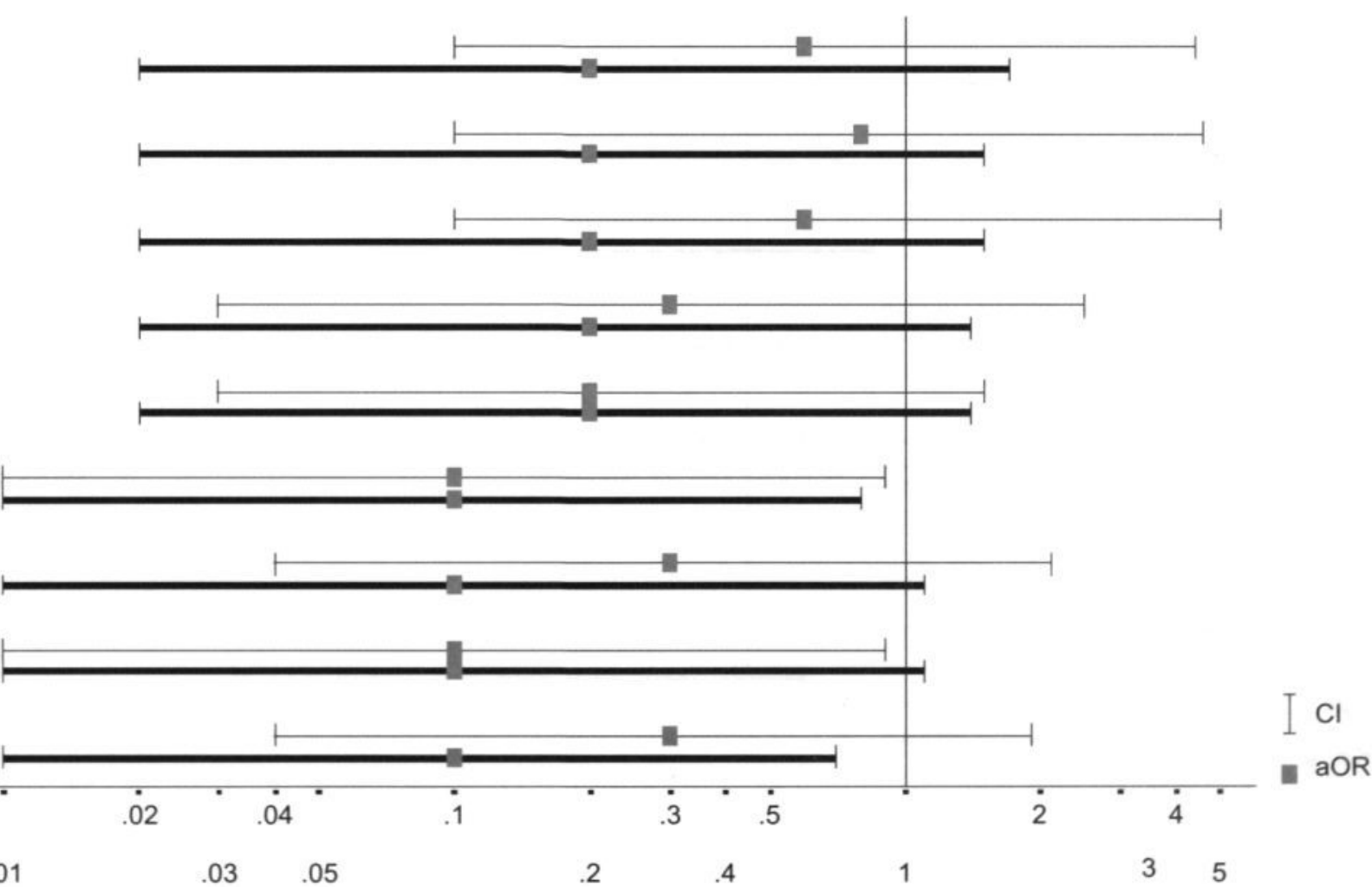


Variability

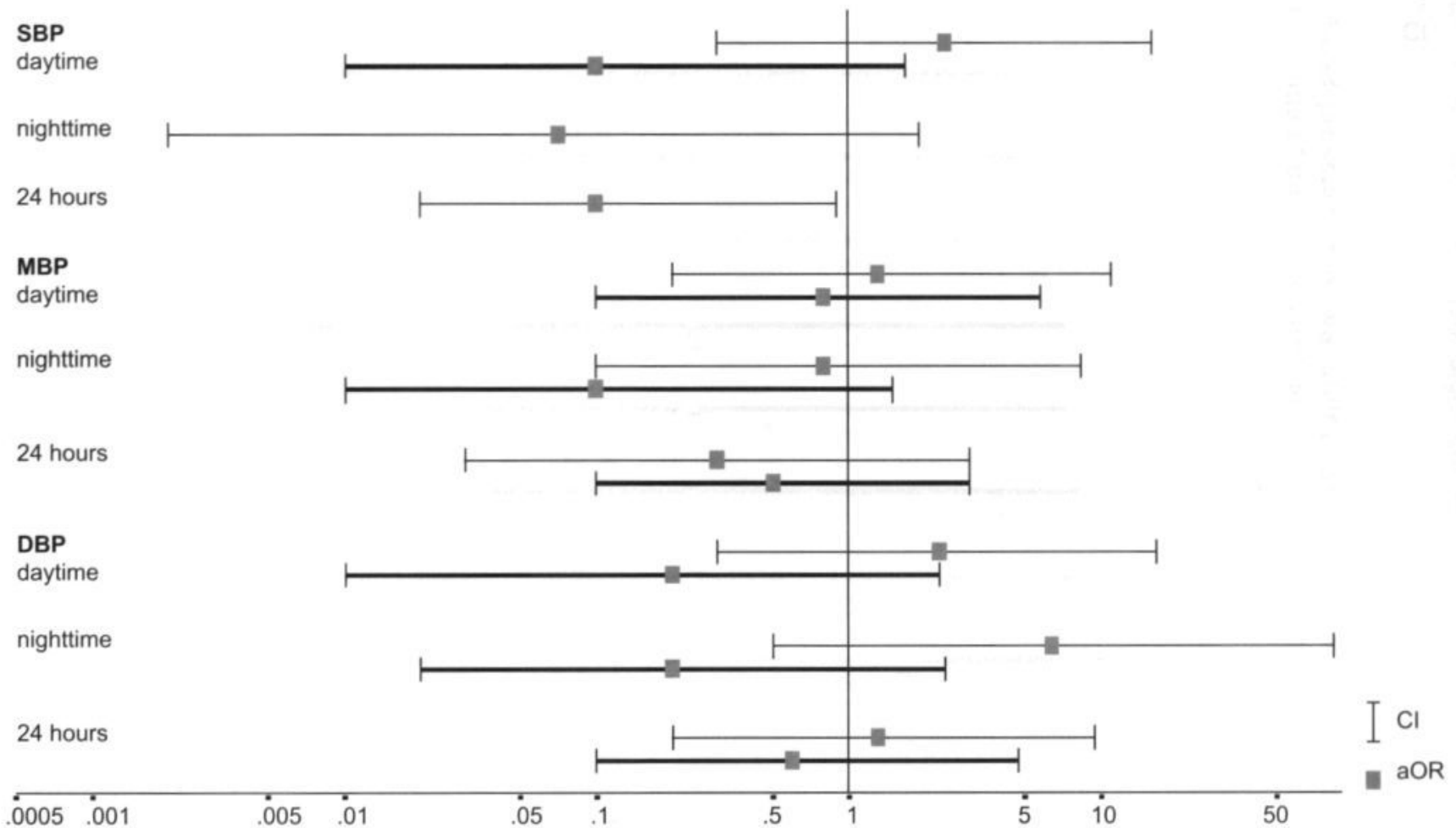


Nocturnal dip and Percentage of dipping

$\infty$

Dip

SBP

MBP

DBP

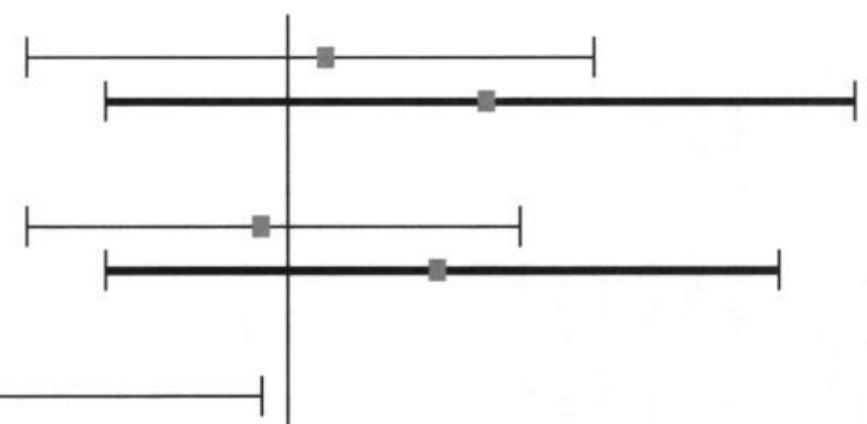

Percentage of dipping

SBP

PD MBP

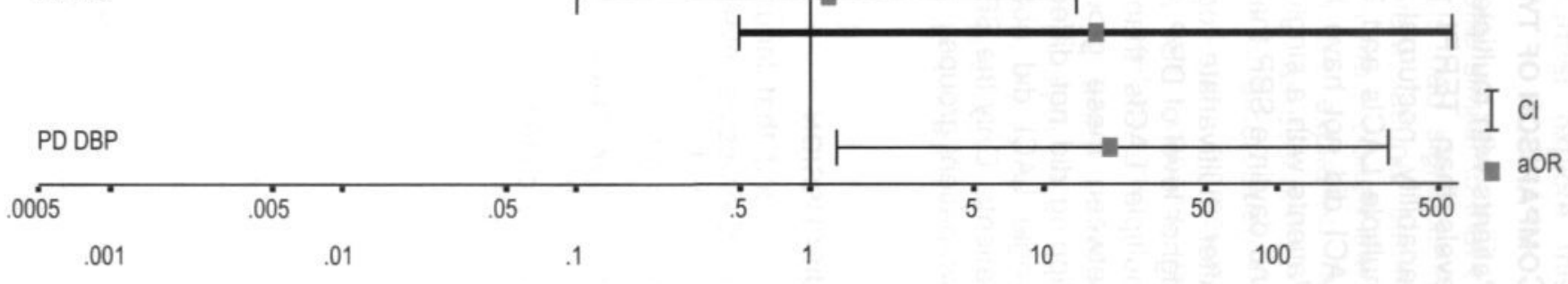




\section{COMPARISON OF TWO LACI TYPES WITH TERRI}

Patients with multiple LACls had significantly higher SBP, MBP and DBP levels than TERRI patients. There were no significant differences in variability, nocturnal dip or percentage of dipping between patients with multiple LACls and TERRI patients. By contrast, patients with a single $\mathrm{LACl}$ did not have higher blood pressure levels than TERRI patients. Patients with a single $\mathrm{LACl}$ had significantly lower variability of nighttime and daytime SBP than TERRI patients.

After multivariate logistic regression analysis, we found a significantly higher level of DBP and MBP (except for nighttime MBP) in patients with multiple LACls than in TERRI patients, whereas SBP did not differ between these groups. Variability, nocturnal dip and percentage of dipping did not differ between these two groups either. Patients with a single LACI did not have higher blood pressure levels than TERRI patients. Only the SBP variability during the night differed between these two patient groups.

\section{Discussion}

We found that lacunar stroke patients with multiple LACls had higher blood pressure levels than those with a single LACI. DBP in particular seems to be a factor associated with the development of multiple LACls. Patients with multiple LACIs also had a higher variability of SBP.

Only a few studies have assessed blood pressure differences between these two lacunar stroke subgroups $[23,26]$. Diastolic blood pressure on admission to hospital has been found to be higher in patients with multiple $\mathrm{LACl}$ s than in those with a single LACI [23]. One study [28] found that high blood pressure variability was associated with multiple LACls but not with single $\mathrm{LACl}$. Compared to controls, the percentage of dipping was smaller in patients with multiple LACls [32].

We found a higher occurrence of hypertension in patients with multiple $\mathrm{LACls}$ than in those with a single $\mathrm{LACl}$, but this difference was not significant. Earlier studies [23, 25, 26, 159] have found a history of hypertension to be associated with the occurrence of multiple LACls on brain imaging, in comparison with patients with a single LACI, TERRI and controls. Our patient group was smaller than those in these previous studies. This may explain the fact that the differences that we found were not statistically significant. Patients with multiple LACls tended to report hypertension more often than the other patient groups, and a larger study, 
involving more patients, would be needed to further explore this difference.

Patients with a single $\mathrm{LACl}$ had a blood pressure profile similar to that of TERRI patients, whereas those with multiple LACls had significantly higher blood pressure than TERRI patients. Therefore, lacunar stroke patients with a single LACI resemble TERRI patients more closely than patients with multiple LACls. These results can be explained by considering the pathogenesis of these stroke subtypes, as described by Fisher [19]. Single LACls and TERRIs are the result of atherosclerosis occurring in cerebral arteries with smaller and larger diameters, respectively (see chapter 1). Multiple LACls are caused by arteriolosclerosis, which is a distinct type of cerebral vessel disease.

Our results are in line with earlier studies [23, 159], which found a significantly higher DBP on admission in patients with multiple LACls, but not with a single LACI, compared to patients with 'non-lacunar stroke' or TERRI. One study [32] found nocturnal dipping to be comparable in these infarct subgroups, but another [28] found it to be blunted in patients with multiple LACIs.

Our study supports our theory that patients with multiple LACls must be distinguished from patients with a single LACI [26]. Moreover, patients with a single LACI showed blood pressure characteristics similar to those of TERRI patients. In other words, our results suggest a difference in blood pressure level and variability between patients with presumed arteriolosclerosis and patients with presumed microatheromatosis. Furthermore, there seems to be a clear difference between patients with presumed arteriolosclerosis but not microatheromatosis and patients with large vessel atheromatosis. 


\title{
CHAPTER 6C: BLOOD PRESSURE VARIABILITY AND STROKE: THE LEVEL OF BLOOD PRESSURE AND ITS VARIABILITY IN RELATION TO THE EXTENT OF WHITE MATTER LESIONS AND PERIVENTRICULAR HYPERINTENSITIES
}

\begin{abstract}
Objective: in many studies, white matter lesions (WMLs) have been regarded as a manifestation of hypertensive target organ damage (TOD). However, some studies have failed to find an association between WML and hypertension in stroke patients. It is important to distinguish between WMLs and Periventricular Hyperintensities (PVHs), because the latter are not associated with vascular risk. Moreover, other aspects of blood pressure, such as blood pressure variability and nocturnal blood pressure decline (nocturnal dip) may determine TOD. Therefore, we studied 24-hour blood pressure profiles in relation to WMLs and PVHs in stroke patients.
\end{abstract}

Design and Methods: One hundred stroke patients participated in the study. MRI scans were used to identify and to grade the extent of WMLs and PVH. Blood pressure was assessed by 24-hour ambulatory monitoring, about 6 weeks after stroke.

Results: We found that patients with WMLs were significantly older than patients without WMLs. Nighttime systolic blood pressure was lower in patients with severe WML compared to patients with minor WML. Variability and percentage of dipping of systolic blood pressure were greater in patients with severe WML than in patients with minor WML.

Conclusions: Blood pressure fluctuations may be a risk factor for severe WML. Ageing seems to increase the importance of this risk factor. 


\section{INTRODUCTION}

White matter lesions (WMLs), that is, hyperintensities in the subcortical white matter on MRI, have been associated in most studies with hypertension and with blood pressure levels. The extent of WMLs varies between treated hypertensives, untreated hypertensives and normotensives $[13,64,168,169,181,188,189,190,192]$. WMLs may therefore be regarded as a type of target organ damage. Others, however, have failed to find an association between WML and hypertension in stroke patients [191].

Earlier studies of the relationship between blood pressure and white matter lesions have used various methods of measuring blood pressure. Moreover, variability and the circadian rhythm of blood pressure have not often been considered in these studies. It is important to consider these aspects of blood pressure profile, because increased blood pressure variability and blunted nocturnal dipping are risk factors for vascular disease. Furthermore, it is important to distinguish WMLs from periventricular hyperintensities (PVHs), because, contrary to WMLs, $\mathrm{PVHs}$ are not related to vascular risk factors or clinical signs $[167,170$, 175]. As WMLs are the result of vascular disease, that is, small vessel disease, we expected blood pressure level, variability and nocturnal rhythm to be risk factors for the extent of WML but not of PVH, because the latter are not related to vascular risk factors.

We therefore investigated blood pressure level, variability and circadian blood pressure profile in relation to WMLs and PVHs in stroke patients using 24-hour ambulatory blood pressure measurements.

\section{PATIENTS AND METHODS}

Patients and methods have been extensively described in chapter 2 . The following analyses were performed:

1) Baseline characteristics (Mann Whitney test, chi squared test)

2) Comparison of blood pressure level between patient subgroups ( $T$ - test).

3) Investigating the relationship between blood pressure level and severity of WML and PVH (Multivariate logistic regression analysis). 


\section{RESULTS}

Because MRI is more sensitive than CT in identifying WMLs and PVHs, we used only the 81 patients who underwent MRI in the subsequent analysis. Of these, $53(65 \%)$ had WML. Ten patients (19\%) had WML grade 1 , while $6(11 \%)$ had WML grade 2 and $37(70 \%)$ had WML grade 3.

Seventy-seven patients (95\%) had PVH. Of these, 57 (74\%) had PVH grade 1 and $20(26 \%)$ had $\mathrm{PVH}$ grade 2.

\section{Baseline characteristics}

The baseline characteristics of our study patients are presented in table 6.4. Results are presented as mean (SD) or number (percentage) of individuals. Patients are classified according to severity of WMLs and PVHs. Patients with WMLs were significantly older than those without WMLs. Patients with severe PVH were significantly older and significantly more often had a history of diabetes than those with minor PVH.

Table 6.4: Baseline characteristics according to severity of WMH and PVH

\begin{tabular}{lllll}
\hline Characteristics & WMH absent & WMH present & Minor PVH & Severe PVH \\
& $\mathrm{n}=28(35 \%)$ & $\mathrm{n}=53(65 \%)$ & $\mathrm{n}=61(74 \%)$ & $\mathrm{n}=20(26 \%)$ \\
& $\mathrm{N}(\%)$ & $\mathrm{N}(\%)$ & $\mathrm{N}(\%)$ & $\mathrm{N}(\%)$ \\
\hline Age $^{\dagger}$ & $56(14)$ & $67(11)$ & $60(13)$ & $73(6) \mathbf{2}$ \\
Male gender & $16(59 \%)$ & $29(55 \%)$ & $34(57 \%)$ & $11(55 \%)$ \\
Hypertension & $10(37 \%)$ & $25(47 \%)$ & $26(43 \%)$ & $9(45 \%)$ \\
Diabetes Mellitus & $2(7 \%)$ & $12(23 \%)$ & $7(12 \%)$ & $7(35 \%)$ - \\
Vascular disease & $11(41 \%)$ & $29(55 \%)$ & $28(47 \%)$ & $12(60 \%)$ \\
Smoking & $14(52 \%)$ & $16(30 \%)$ & $26(43 \%)$ & $4(20 \%)$ \\
\hline
\end{tabular}

$\dagger$ Results are expressed as mean (SD)
(1) $\mathrm{p}=0.017$
(2) $\mathrm{p}<0.0001$

\section{BLOOD PRESSURE AND WML}

Table 6.5 shows the blood pressure characteristics of the stroke patients. Patients are classified according to severity of WML. Results are presented as blood pressure levels, nocturnal dip and percentage of dipping and median standard deviation. Patients with WML had higher blood pressure levels than patients without WML. For nighttime SBP and MBP and daytime MBP and DBP, this difference was statistically significant. Variability of blood pressure was significantly higher in 
patients with WML than in patients without WML. We found no differences in nocturnal dip or percentage of dipping between patients with and without WML.

Table 6.5: Blood pressure, variability (expressed as SD), nocturnal dip and diprate according to severity of WMH and PVH

\begin{tabular}{|c|c|c|c|c|c|c|c|}
\hline \multicolumn{2}{|c|}{ blood pressure } & $\begin{array}{l}\text { WMH } \\
\text { absent } \\
(28) \\
{[35 \%]}\end{array}$ & $\begin{array}{l}\text { WMH } \\
\text { present } \\
(53) \\
{[65 \%]}\end{array}$ & $\begin{array}{l}\text { Punctate } \\
\text { WMH } \\
\text { (16) } \\
{[30 \%]}\end{array}$ & $\begin{array}{l}\text { Severe } \\
\text { WMH } \\
(37) \\
{[70 \%]}\end{array}$ & $\begin{array}{l}\text { Minor } \\
\text { PVH (61) } \\
{[74 \%]}\end{array}$ & $\begin{array}{l}\text { Severe } \\
\text { PVH (20) } \\
{[26 \%]}\end{array}$ \\
\hline \multicolumn{8}{|c|}{ 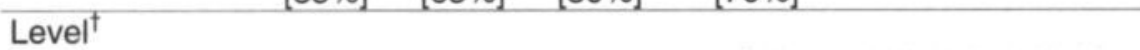 } \\
\hline \multirow{3}{*}{ SBP } & Daytime & 139 & 148 & 150 & 148 & 145 & 144 \\
\hline & Nighttime & 126 & $137^{*}$ & 137 & 138 & 133 & 134 \\
\hline & 24- hour & 139 & 145 & 143 & 146 & 143 & 142 \\
\hline \multirow[t]{3}{*}{ MBP } & Daytime & 101 & $109^{*}$ & 111 & 108 & 106 & 106 \\
\hline & Nighttime & 90 & $98^{*}$ & 98 & 98 & 96 & 94 \\
\hline & 24- hour & 100 & 106 & 106 & 106 & 105 & 102 \\
\hline \multirow[t]{3}{*}{ DBP } & Daytime & 81 & $89^{*}$ & 91 & 88 & 86 & 86 \\
\hline & Nighttime & 72 & 78 & 79 & 78 & 77 & 73 \\
\hline & 24-hour & 81 & 86 & 87 & 86 & 85 & 83 \\
\hline \multicolumn{8}{|c|}{ Variability ${ }^{\ddagger}$} \\
\hline \multirow[t]{3}{*}{ SBP } & Daytime & 14 & $17^{\star}$ & 17 & 17 & 15 & 18 \\
\hline & Nighttime & 9 & $12^{*}$ & 10 & 15 & 10 & $13^{*}$ \\
\hline & 24- hour & 16 & $17^{*}$ & 17 & 18 & 17 & 19 \\
\hline \multirow[t]{3}{*}{ MBP } & Daytime & 12 & $14^{*}$ & 14 & 14 & 13 & 14 \\
\hline & Nighttime & 7 & $11^{*}$ & 10 & 11 & 9 & $12^{*}$ \\
\hline & 24- hour & 13 & $14^{*}$ & 14 & 15 & 14 & 15 \\
\hline \multirow{3}{*}{ DBP } & Daytime & 13 & $15^{*}$ & 15 & 15 & 13 & 15 \\
\hline & Nighttime & 8 & $11^{*}$ & 10 & 11 & 8 & $12^{*}$ \\
\hline & 24-hour & 13 & $15^{*}$ & 16 & 16 & 14 & 15 \\
\hline \multicolumn{8}{|l|}{$\operatorname{Dip}^{\dagger}$} \\
\hline \multicolumn{2}{|l|}{ SBP } & 14 & 12 & 9 & 13 & 14 & 10 \\
\hline \multicolumn{2}{|l|}{ MBP } & 12 & 12 & 12 & 13 & 13 & 14 \\
\hline \multicolumn{2}{|l|}{ DBP } & 10 & 13 & 13 & 12 & 13 & 12 \\
\hline \multicolumn{8}{|c|}{ Percentage of dipping ${ }^{\dagger}$} \\
\hline \multicolumn{2}{|l|}{ SBP } & 10 & 8 & 6 & 8 & 10 & 6 \\
\hline \multicolumn{2}{|l|}{ MBP } & 11 & 11 & 10 & 11 & 13 & 12 \\
\hline \multicolumn{2}{|l|}{ DBP } & 12 & 14 & 14 & 14 & 16 & 14 \\
\hline
\end{tabular}

† Mean

$\ddagger$ Median

* Significant difference 
Figure 6.4: Comparison between patients according to severity of WML (severe WML vs. Punctate WML); Cl and aOR for 1st vs 2nd tertile and 1st vs 3rd tertile.

Blood pressure level

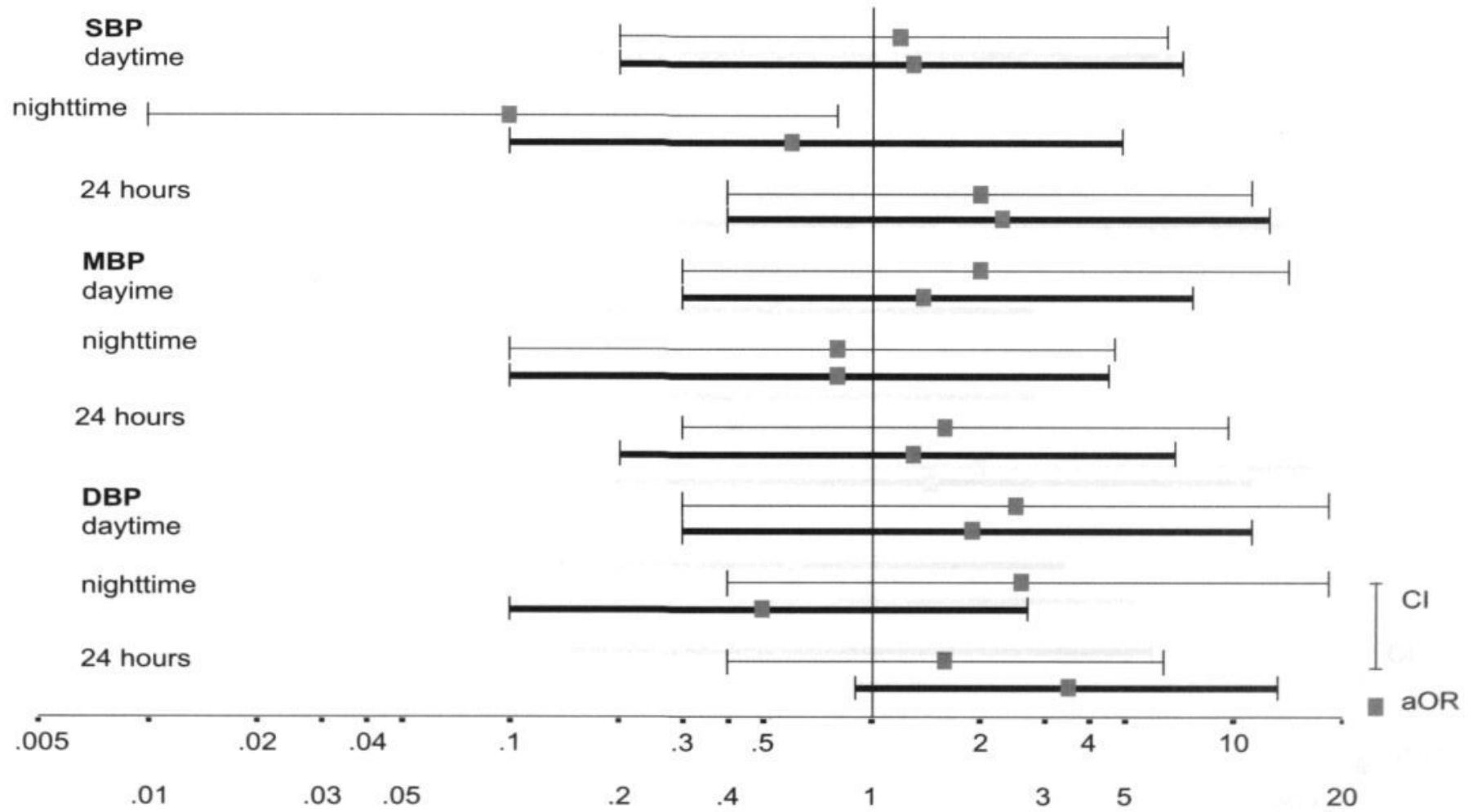




\section{Variability}

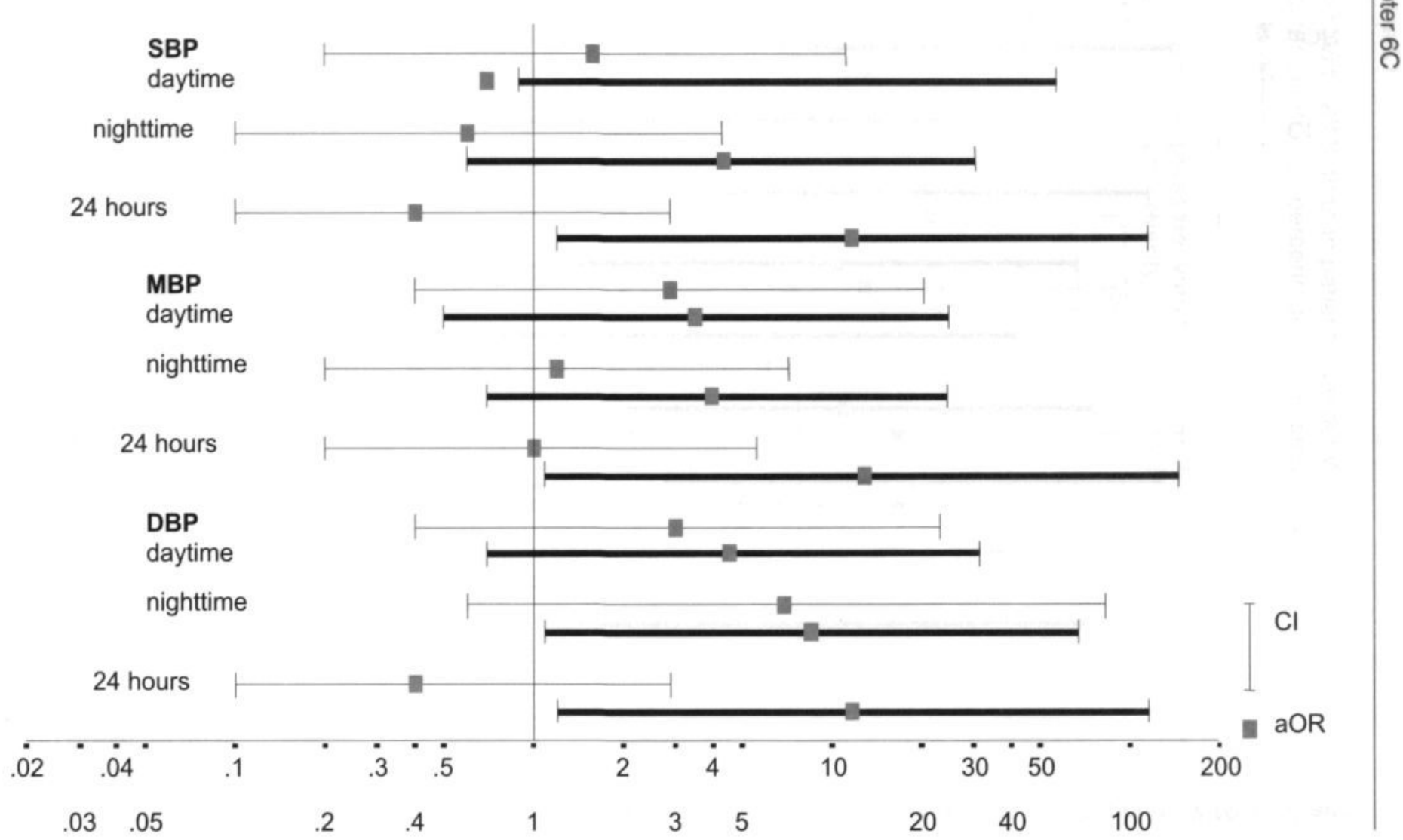


Nocturnal dip and Percentage of dipping

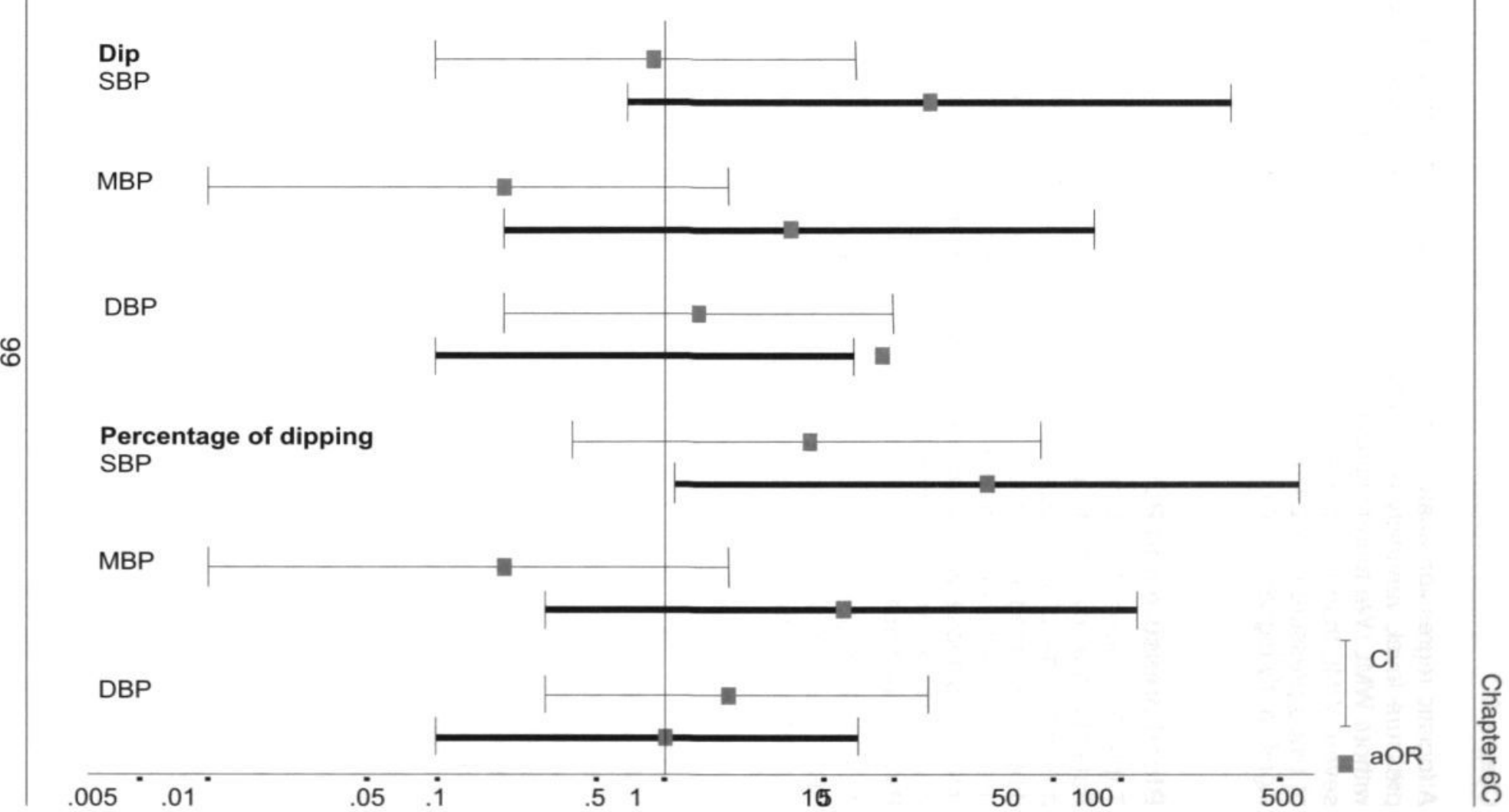


A logistic regression analysis revealed no significant differences in blood pressure level, variability or circadian rhythm between patients with and without WML. We found significantly lower nighttime SBP in patients with severe WML than in patients with punctate WML. Furthermore, variability of blood pressure over 24 hours and percentage of dipping of SBP were significantly higher in patients with severe WML (figure 6.4).

\section{Blood pressure and PVH}

Table 6.5 shows the blood pressure characteristics the stroke patients. Patients are classified according to severity of PVH. Results are presented as blood pressure levels, nocturnal dip and percentage of dipping and median standard deviation. We found no difference in blood pressure level, nocturnal dip or circadian rhythm between patients with minor and those with severe PVH. Nighttime blood pressure variability was significantly higher in patients with $\mathrm{PVH}$ grade 2 than in those with $\mathrm{PVH}$ grade 0 or 1 .

After multivariate logistic regression analysis. We found that nighttime SBP was significantly lower, and 24-hour variability of SBP was significantly higher in patients with severe $\mathrm{PVH}$ than in those with minor $\mathrm{PVH}$.

\section{Discussion}

We found that stroke patients with WML had blood pressure characteristics similar to those of stroke patients without WML, although blood pressure levels tended to be lower in patients without WML. Stroke patients with severe WML had higher nighttime SBP, higher 24-hour variability and a higher percentage of dipping of SBP than patients with punctate WML. However, these results should be interpreted with caution, in view of the small number of patients in each subgroup.

Contrary to ours, most earlier studies have found that WML are associated with hypertension. Our study was performed in a population of stroke patients, whereas other studies of WMLs and blood pressure have been population-based studies. Hypertension and raised blood pressure as well as WMLs occur more often in stroke patients than in the general population. Furthermore, hypertension is a risk factor for stroke as well as for WMLs. Also, it is impossible to select patients according to the severity of WMLs, because this is an MRI-finding. 
The prevalence of WML in our stroke patients was $65 \%$, which, as could be expected, is higher than that reported in the general population [36, 80,162 ]. Moreover, our study included a high percentage of patients with LACI (40\%).

Blood pressure level and variability as well as decreased nocturnal dip are associated with the presence and subsequent development of TOD such as WML. Development of TOD is more closely related to nighttime blood pressure than to daytime pressure $[16,32,45,59,61,62,63,75$, $86,87]$. Earlier studies have found that the volume of WML in stroke patients correlated with daytime and nighttime systolic blood pressure level, but not with the nocturnal dip in SBP [169] measured 6 months after the stroke. In a population-based study which included 58 stroke patients, the prevalence of WML varied with SBP and DBP levels measured by mercury manometer, but only within a specified age range [177].

Stroke patients with severe PVH had blood pressure characteristics similar to those in patients with minor $\mathrm{PVH}$, except for a significantly lower nighttime MBP and higher 24-hour SBP variability. Earlier studies have found no relation between $\mathrm{PVH}$ and vascular risk factors or clinical signs $[167,170,175]$.

Our study supports and expands on these earlier results, but a larger study group would be needed to explore the relation between blood pressure characteristics and the extent of WML. Also, results are difficult to compare because WMLs have often not been differentiated from $\mathrm{PVH}$. The higher nighttime blood pressure values that we found in our T-test may have been due to the difference in age between the patient groups. In our logistic regression analysis, we corrected for differences in age and vascular risk factors. We found that besides a high 24-hour variability, a low nighttime level of SBP and a large nighttime percentage of SBP dipping were associated only with extensive WML. The age difference cannot explain this phenomenon. An alternative explanation may be the following.

WMLs have been associated with arteriolosclerosis, or lipohyalinosis $[160,161,167,193,194,196,197]$. This is one of two distinct types of small vessel disease, as described in chapter 1. High 24-hour blood pressure variability, and a relatively large nocturnal drop in SBP to a low nighttime level may therefore be associated with arteriolosclerosis and may result in the occurrence of WMLs.

We confirmed an association between WML and stroke. Our study group may have been too small to confirm a relationship between daytime blood pressure level and the extent of WML in stroke patients. However, our results do suggest that blood pressure fluctuations may be a risk factor 
for extensive WML. This would mean that 24-hour ambulatory blood pressure measurement, which allows for investigation of blood pressure variability and differences between daytime and nighttime blood pressure, may be important for the assessment of the risk of extensive WMLs. Further study is needed to explore this. 


\section{CHAPTER 6D: BLOOD PRESSURE VARIABILITY AND STROKE: NOCTURNAL DIPPING IS ASSOCIATED WITH THE STROKE LESION SITE}

\section{Abstract}

Objective: Changes in sympathetic and/or parasympathetic function after stroke may manifest themselves as an abnormal blood pressure variability and diurnal blood pressure rhythm. These changes occur especially after right-sided cortical infarcts. The site of the lesion may, therefore, influence 24-hour blood pressure profiles after stroke. It is unclear whether these changes are temporary or sustained in the chronic phase of stroke. We therefore investigated blood pressure profile in relation to the localisation of the stroke lesion, in the acute phase as well as in the chronic phase after the stroke.

Design and Methods: One hundred stroke patients participated in this study. MRI and CT scans were used to define stroke subtype. Blood pressure was assessed by 24-hour ambulatory monitoring, about 1 week (acute phase) and about 6 weeks (chronic phase) after stroke.

Results: We found that $52 \%$ of or patients with right-sided cortical infarcts had a nocturnal rise in blood pressure in the acute phase of stroke. We also found a transient blunting of the nocturnal dip in patients with right-sided cortical infarcts.

Conclusions: Transient changes in 24-hour blood pressure profiles occur in patients with right- sided cortical infarcts. They need to be closely monitored in a stroke unit in the acute phase of stroke, because these changes in blood pressure profile may lead to serious complications. 


\section{INTRODUCTION}

The autonomic nervous system is one of the factors involved in transient variations in blood pressure resulting from individual activities and emotions. The right temporal cortex predominantly regulates sympathetic activity. After a stroke, especially one in the right hemisphere, sympathetic hyperfunction and parasympathetic hypofunction may occur $[31,79,81,82]$. These changes may manifest themselves as abnormal variability and diurnal blood pressure rhythm, which can be studied using 24-hour ambulatory blood pressure measurement. The site of the stroke lesion may therefore influence the blood pressure level or its variability $[29,30,83]$. It is unclear whether these changes are temporary or sustained in the chronic phase of stroke.

We therefore investigated blood pressure level, variability, nocturnal dip and percentage of dipping using 24-hour ambulatory blood pressure monitoring in stroke patients in relation to the localisation of the stroke lesion, in the acute phase as well as in the chronic phase (about 6 weeks after the stroke). Because the clinical complications usually occur in the acute phase only, we expected a temporary change in diurnal blood pressure rhythm.

\section{PATIENTS AND METHODS}

Patients and methods have been extensively described in chapter 2 . The following analyses were performed:

1) Baseline characteristics (Mann Whitney test, chi squared test)

2) Comparison of blood pressure level, blood pressure variability and nocturnal dip in the acute phase of stroke, between patient subgroups (T- test)

3) For any significant changes found, the above procedure was repeated for measurements in the chronic phase (T- test).

\section{RESULTS}

Of the 100 stroke patients who entered the study, $81(81 \%)$ underwent both CT and MRI scanning, while 19 patients (19\%) underwent only CT scanning. As described in chapter 3, CT and MRI diagnoses were in good agreement. Therefore, in order to obtain the largest possible patient group, we used all patients in the subsequent analysis. 
Of the 100 stroke patients who entered the study, $47(47 \%)$ had a CORTI and $38(38 \%)$ had a lacunar lesion (LACl); 51 patients $(51 \%)$ had a rightsided lesion and 49 (49\%) had a left-sided lesion.

\section{Baseline characteristics}

The baseline characteristics of the stroke patients are shown in table 6.6. Results are presented as number of patients (percentage of patients). Patients with right-sided lesions were significantly older and had significantly more cardiovascular events in their history than patients with left-sided lesions. The risk factor profile was similar for patients with cortical infarcts and those with lacunar infarcts.

Table 6.6: Baseline characteristics according to lesion site

\begin{tabular}{lllll}
\hline Lesion site & $\begin{array}{l}\text { Cortical (47) } \\
{[47 \%]}\end{array}$ & $\begin{array}{l}\text { Lacunar (38) } \\
{[38 \%]}\end{array}$ & $\begin{array}{l}\text { Right-sided } \\
(51)[51 \%]\end{array}$ & $\begin{array}{l}\text { Left- sided } \\
(49)[49 \%]\end{array}$ \\
\hline Age $^{\dagger}$ & $65(13)$ & $65(12)$ & $68(11 \%)$ & $62(13)^{\star}$ \\
Male gender & $25(53 \%)$ & $21(55 \%)$ & $24(47 \%)$ & $32(65 \%)$ \\
Hypertension & $20(43 \%)$ & $18(47 \%)$ & $25(49 \%)$ & $20(41 \%)$ \\
Diabetes mellitus & $7(15 \%)$ & $10(26 \%)$ & $11(22 \%)$ & $7(14 \%)$ \\
Vascular disease & $22(47 \%)$ & $16(42 \%)$ & $28(55 \%)$ & $17(35 \%)^{\star}$ \\
Smoking & $17(36 \%)$ & $15(40 \%)$ & $16(31 \%)$ & $20(41 \%)$ \\
\hline
\end{tabular}

$\dagger$ Results expressed as mean (SD)

* Significant difference

\section{Differences in the acute phase of stroke}

We found that, in the acute phase of stroke, daytime and 24-hour blood pressure levels were significantly higher in patients with $\mathrm{LACl}$ than in those with cortical infarcts. Nocturnal dip and percentage of dipping of SBP and MBP were significantly lower in patients with right-sided infarcts than in those with left-sided infarcts. Similarly, we found that nocturnal dip and percentage of dipping of SBP and MBP were significantly lower in patients with a right-sided cortical infarct than in those with a left-sided cortical infarct, but no difference was found between patients with leftand right-sided LACls (table 6.7a). Fourteen patients (52\%) with a rightsided cortical infarct even had a nocturnal rise in SBP, while 12 patients $(44 \%)$ had a nocturnal rise in MBP. 
Table 6.7: Blood pressure, variability, dip and percentage of dipping according to stroke lesion site

a. Acute phase

\begin{tabular}{lllll}
\hline blood & LACI & & CORTI & \\
pressure & Right & Left & Right & Left \\
& $n=16$ & $n=22$ & $n=27$ & $n=20$ \\
& $(42 \%)$ & $(58 \%)$ & $(57 \%)$ & $(43 \%)$ \\
\hline
\end{tabular}

Level $^{\dagger}$

$\begin{array}{llllll}\text { SBP } & \text { Daytime } & 150 & 154 & 143 & 142 \\ & \text { Nighttime } & 145 & 145 & 144 & 133 \\ & \text { 24- hours } & 149 & 152 & 144 & 136 \\ \text { MBP } & \text { Daytime } & 110 & 113 & 103 & 104 \\ & \text { Nighttime } & 104 & 106 & 102 & 96 \\ & \text { 24- hours } & 108 & 112 & 103 & 101 \\ \text { DBP } & \text { Daytime } & 90 & 93 & 83 & 85 \\ & \text { Nighttime } & 83 & 86 & 81 & 87 \\ & \text { 24- hours } & 88 & 92 & 83 & 83\end{array}$

Variability ${ }^{\ddagger}$

\begin{tabular}{llllll} 
SBP & Daytime & 14 & 16 & 15 & 14 \\
& Nighttime & 12 & 16 & 13 & 9 \\
MBP & 24-hours & 14 & 17 & 15 & 16 \\
& Daytime & 13 & 14 & 13 & 12 \\
& Nighttime & 10 & 11 & 11 & 9 \\
\multirow{2}{*}{ DBP } & 24-hours & 13 & 14 & 13 & 13 \\
& Daytime & 15 & 13 & 13 & 11 \\
& Nighttime & 10 & 11 & 10 & 7 \\
& 24- hours & 15 & 13 & 13 & 13
\end{tabular}

Dip $^{\dagger}$

$\begin{array}{lllll}\text { SBP } & 5 & 9 & -1.2 & 9^{*} \\ \text { MBP } & 7 & 7 & 1.3 & 8^{*} \\ \text { DBP } & 8 & 7 & 2.5 & 8\end{array}$

Percentage of dipping ${ }^{\dagger}$

\begin{tabular}{lllll} 
SBP & 3 & 6 & -0.5 & $7^{\star}$ \\
MBP & 6 & 7 & 1.3 & $8^{*}$ \\
DBP & 8 & 7 & 2.5 & $10^{*}$ \\
\hline
\end{tabular}

† Mean

$\ddagger$ Median 


\section{b. Chronic phase}

\begin{tabular}{|c|c|c|c|c|}
\hline \multirow[t]{2}{*}{ blood pressure } & \multicolumn{2}{|l|}{$\mathrm{LACl}$} & \multicolumn{2}{|l|}{ CORTI } \\
\hline & $\begin{array}{l}\text { Right } n=16 \\
(58 \%)\end{array}$ & $\begin{array}{l}\text { Left } n=22 \\
(58 \%)\end{array}$ & $\begin{array}{l}\text { Right } n=27 \\
(57 \%)\end{array}$ & $\begin{array}{l}\text { Left } n=20 \\
(43 \%)\end{array}$ \\
\hline
\end{tabular}

Dip $^{\dagger}$

$\begin{array}{lllll}\text { SBP } & 9 & 13 & 7.9 & 11 \\ \text { MBP } & 13 & 11 & 6.6 & 11 \\ \text { DBP } & 14 & 10 & 6.2 & 12\end{array}$

Percentage of dipping ${ }^{\dagger}$

\begin{tabular}{lllll} 
SBP & 6 & 9 & 5.4 & 8 \\
MBP & 12 & 10 & 6 & 11 \\
DBP & 15 & 11 & 6.3 & 14 \\
\hline
\end{tabular}

$\dagger$ Mean

* Significant difference in acute phase

** Significant difference in chronic phase

\section{Differences in the chronic phase of stroke}

In the chronic phase of stroke, we found that daytime and 24-hour blood pressure levels were significantly higher in patients with $\mathrm{LACl}$ than in patients with cortical infarcts. Contrary to the acute phase, we found no other significant differences in the chronic phase (table 6.7b).

\section{Discussion}

We found that in the acute phase of stroke, but not in the chronic phase, patients with a right-sided stroke had significantly reduced nocturnal dip and percentage of dipping of SBP and MBP compared to patients with a left-sided stroke. We further divided these patient groups into patients with cortical and lacunar infarcts, and found that only patients with rightsided cortical infarcts had significantly lower nocturnal dip and percentage of dipping of SBP and MBP than patients with left-sided cortical infarcts. It is unlikely that these differences were related to the significant difference in age between patients with right-sided and left-sided lesions, because they were temporary.

It has been shown that patients with stroke show decreased nocturnal dipping compared to controls. Patients with right-sided and insular stroke 
have been found to show less dipping than those with left-sided or noninsular stroke [27, 31, 42, 128, 133, 140, 141]. Also, blood pressure variability is increased in the acute phase of stroke [130, 142]. Blood pressure variability and nocturnal dipping are influenced by the autonomic nervous system [31]. Furthermore, it has been shown in experimental studies and in stroke patients that there is a dysregulation of the autonomic nervous system in the acute phase of stroke [29, 30, 82, 141], with sympathetic hyperfunction and parasympathetic hypofunction [83, $138,144]$. This may explain the changes in blood pressure variability and nocturnal dip. It is unclear how long these differences persist. Our results suggest that these changes are transient, as they disappeared within a few weeks.

Acute changes in variability and nocturnal dip may be associated with serious complications such as cardiac arrhythmia and cardiac ischaemic changes in the absence of coronary artery disease. These complications occur in the acute phase of stroke [31]. It is therefore important to identify patients who may be at risk of these serious complications after stroke. Our results confirm that changes in nocturnal dipping occur in patients with right-sided cortical infarcts. Therefore, these patients should be monitored in the acute phase.

It is important to note that the level of blood pressure as well as the blood pressure variability are not associated with the lesion site, but with the stroke subtype (see chapters 5 and 6). Also, the changes in diurnal blood pressure rhythm do not persist in the chronic phase of stroke. Therefore, extra vigilance seems necessary for patients with right-sided lesions in the acute phase of stroke. 


\section{GenerAL Discussion}


A stroke can happen suddenly, and may irreversibly change the patient's life. It remains for the doctor to elucidate the most likely cause, and to give advice for the future. Part of this advice concerns blood pressure management. Some patients have no idea of their pre-stroke blood pressure, and therefore post- stroke blood pressure measurements are the only source of information. We have tried in this study to shed more light on the importance of some post-stroke blood pressure characteristics for the pathogenesis of stroke.

\section{CAN POST-STROKE BLOOD PRESSURE PROVIDE INSIGHT INTO PRE- EXISTENT HYPERTENSION AND THE NEED FOR TREATMENT?}

Our study shows that post-stroke blood pressure measurements in the chronic phase (about 6 weeks after the stroke) closely reflect pre-stroke blood pressure, and may therefore be used to identify patients with hypertension (chapter 3). We cannot exclude, however, the occurrence of selection bias in the collection of these data and their validity. Hypertension is the most important modifiable risk factor for stroke, and treatment of hypertension reduces the risk of recurrent stroke. The question is, how soon after a stroke occurs can hypertension be diagnosed? Blood pressure measurements in the acute phase of stroke cannot be used to predict blood pressure in the chronic phase, because a transient rise in blood pressure normally occurs in the acute phase (chapter 4). Our study shows that blood pressure measurements in the acute phase of stroke do not predict hypertension after 6 weeks (chapter 4). Therefore the decision to treat hypertension after stroke should be taken in the chronic phase to avoid the risk of inappropriately lowering the blood pressure in stroke patients. Nevertheless, extremely high blood pressure should be treated if it occurs in the acute phase of stroke.

\section{DO PATIENTS WITH STROKE DIFFER FROM CONTROLS WITH RESPECT TO 24- HOUR BLOOD PRESSURE PROFILES?}

We found that, compared to controls, the total group of brain infarct patients had higher blood pressure levels, greater variability of blood pressure and less nocturnal pressure decline. Blood pressure variability and nocturnal pressure decline differed more clearly from controls in patients with TERRI than in patients with LACI. A greater blood pressure variability with a blunted nocturnal fall in blood pressure is consistent with enhanced sympathetic activity. One reason for such an enhancement could be site of the stroke lesion. Another reason could stem from brain 
ischaemia as such (the Cushing reflex). Unfortunately, the design of our study did not allow us to study sympathetic mechanisms in more detail.

Our results show that not only blood pressure level, but also blood pressure variability and nocturnal blood pressure decline are important risk factors for stroke. These three aspects of blood pressure can only be studied together using 24-hour ambulatory blood pressure measurement.

\section{HOW DO PATIENTS WITH VARIOUS STROKE SUBTYPES DIFFER?}

Brain infarcts may be caused by 3 types of cerebral vascular disease as extensively described in this thesis. Territorial infarcts may be caused by large- vessel atherosclerosis, and lacunar infarcts may be caused by cerebral small vessel disease, either arteriolosclerosis or small vessel atherosclerosis (microatheromatosis). Hypertension is a risk factor for all these types of brain infarct, and therefore for all these underlying subtypes of cerebral vascular disease. Moreover, the vascular risk factor profile is also similar for these vascular diseases. The question is what determines which type of vascular disease develops in a particular patient. We have therefore investigated whether severity of hypertension determines which type of cerebral vascular disease develops in a patient.

It was interesting to find that blood pressure measured over 24 hours was higher in the patients with LACI than in those with TERRI, although they did not report hypertension more often. Another important finding of the present study is that the blood pressure profile in patients with a single $\mathrm{LACl}$ closely resembled that in patients with TERRI, whereas the level of blood pressure (especially DBP) differed clearly between patients with multiple LACls and those with TERRI or a single LACI. What is the significance of these results?

Our study suggests that the severity of hypertension does indeed determine the type of underlying cerebral vascular disease in ischaemic stroke patients. Patients with more severe hypertension have a higher risk to develop arteriolosclerosis, causing multiple lacunar infarcts. Patients with less severe hypertension have a higher risk to develop cerebral atherosclerosis of either the small vessels (microatheromatosis) or the larger vessels (large vessel atheromatosis or macroatheromatosis), causing a single lacunar infarct or a territorial infarct respectively. As a consequence, in patients who present with multiple lacunar infarcts, hypertension should be treated more diligently.

Hypertension is a strong risk factor for brain infarcts, but it has been considered as a more specific risk factor for lacunar infarcts. However, this issue is controversial due to conflicting pathological and clinical 
studies, and the debate in literature is still going on. We found that prevalence of hypertension is similar in patients with territorial and lacunar infarcts, but hypertension was more sever in the lacunar infarct patients. Therefore, not hypertension itself but its severity plays a role in the development of the type of brain infarct and underlying type of cerebral vascular disease. Furthermore, we found that in the lacunar infarct patients severity of hypertension is specifically important in the patients with multiple lacunar infarcts, due to the arteriolosclerosis- type of small vessel disease. The above is also pathophysiologically plausible. Arteriolosclerosis differs pathophysiologically from the other two types of cerebral disease. Microatheromatosis and macroatheromatosis are identical disease processes (atherosclerosis) taking place in arteries of different size. Arteriolosclerosis is a disease of the vessel wall as described in chapter 1.

\section{SO WHAT TO DO?}

Hypertension, increased blood pressure variability and decreased nocturnal blood pressure decline are all risk factors for stroke. Therefore, it is important to perform blood pressure monitoring in stroke patients. Also, further research should be done to find medication that specifically influences blood pressure variability and nocturnal blood pressure decline. But should all stroke patients undergo 24-hour ambulatory blood pressure measurement? Who can treat and monitor the patient?

Blood pressure in stroke patients is higher than in controls. Blood pressure level, but not its variability or nocturnal decline, differs between patients with different brain infarct subtypes. Specifically, the blood pressure profile determines the occurrence of multiple lacunar infarcts. So, blood pressure measurement and treatment for hypertension are especially important in patients with $\mathrm{LACl}$, and particularly those with multiple LACls. In these patients, hypertension may be the most important cause of their stroke. Therefore, blood pressure measurement should be performed in stroke patients. It should be done in the chronic phase of stroke, to ensure that blood pressure level has plateaued after the stroke. Blood pressure monitoring and treatment can be performed by the patient's general practitioner, which in many cases will be a relief for practical reasons.

Patients with right-sided cortical infarcts form a group requiring special attention in the acute phase of stroke. They have a transient decrease in nocturnal dip, or even a nocturnal rise in blood pressure. These are signs of autonomic dysfunction, which may lead to serious complications such as arrhythmia and signs of ischaemia in the absence of coronary artery 
disease. Comparison of daytime and nighttime blood pressure levels in the acute phase of stroke is therefore essential to identify patients at risk of these complications. Patients with right- sided cortical infarcts need close cardiac monitoring in a stroke unit. Repeated daytime and nighttime blood pressure measurements are required, but these need not necessarily be performed using a 24-hour ambulatory measuring device.

\section{ANSWERS AND MORE QUESTIONS}

We are finding our way around in the riddle of blood pressure profile, stroke subtypes and underlying cerebral vessel disease. Aspects of blood pressure profile play a role in the pathogenesis of stroke. Furthermore, changes occur in the acute phase of stroke that may affect a patient's clinical outcome.

Nowadays, patients arrive at the emergency department sooner after symptoms start. Early intervention in the acute phase of stroke and care in a specialised stroke unit will further improve the prognosis after a stroke. Doctors are thereby given the opportunity to identify, study and modify the most important causal factors.

So life goes on after the stroke and the blood pressure in stroke patients needs attention. Further studies are currently in progress on the prognostic value of the blood pressure course after a stroke. 
SUMMARY 
Although it is generally accepted that hypertension is the most important risk factor for ischaemic stroke, the relationship between blood pressure profile, stroke subtype and underlying cerebral vascular disease has scarcely been investigated.

It is important to investigate this relationship because of the possible preventive and therapeutic consequences for individuals. This must be considered in the light of an ageing world population and increasing exposure to a western lifestyle, which means that an increasing prevalence of hypertension and stroke is expected in the near future. However, a patient may be unaware of the fact that he has hypertension until complications such as stroke occur. In such situations, the only information available is his post-stroke blood pressure. Since blood pressure may rise during the acute phase of stroke, however, the question remains whether blood pressure measurements in the acute phase can be used to decide whether a patient has hypertension and whether treatment should be started.

We therefore compared manometrically measured blood pressure levels before and after the stroke and investigated whether blood pressure levels measured by 24-hour ambulatory measurement in the acute phase of stroke predicted blood pressure in the chronic phase.

Several types of cerebral vessel disease can cause ischaemic infarction. Large vessel atheromatosis may cause territorial infarction, while small vessel disease causes lacunar infarction. Based on earlier studies, we assumed that two lacunar entities exist, presumably caused by two distinct types of cerebral small vessel disease.

Microatheromatosis is a process whereby a small atherosclerotic plaque occludes the origin of a small penetrating arteriole. This process closely resembles large vessel atheromatosis and results in a single lacunar infarct. Arteriolosclerosis, by contrast, is a generalised type of cerebral small vessel disease, resulting in segmental vessel wall destruction with hyalin deposits in the vessel wall of penetrating arterioles, resulting in multiple lacunar infarcts or white matter lesions. Arteriolosclerosis is specifically related to hypertension, whereas the risk factor profile of microatheromatosis is similar to that of large vessel atheromatosis.

Investigating blood pressure as a risk factor for cerebral small vessel disease is difficult because fatality and autopsy rates are relatively low, especially for lacunar stroke, which means that we must depend on circumstantial evidence. We therefore studied blood pressure profiles, using 24-hour ambulatory measurement, in stroke patients compared to controls, and in patients with TERRI compared to patients with LACI. Furthermore, we compared patients with multiple LACI with patients with 
a single $\mathrm{LACl}$, and both $\mathrm{LACl}$ subgroups with TERRI patients. We also used 24-hour non-invasive ambulatory blood pressure measurement to study blood pressure profiles as a risk factor for the severity of white matter lesions seen on MRI scans. Finally, we studied changes in the blood pressure profile after cerebral infarction.

Chapter 3 discusses whether manometrically measured post-stroke blood pressure in the chronic phase (about 6 weeks after the stroke) reliably reflects pre-stroke blood pressure levels. We found that post-stroke measurements did indeed reflect pre-stroke blood pressure. We therefore concluded that post-stroke measurements can be used when studying blood pressure as a causal factor of the patient's stroke. We used poststroke measurements in our subsequent studies, because pre-stroke values were not always available.

Chapter 4 investigates whether blood pressure measurements using a 24-hour ambulatory device in the acute phase (about one week after the stroke) predicted those in the chronic phase of stroke. Although we found reasonably close correlation coefficients of $0.6-0.8$ for the blood pressure level, prediction intervals were very wide. We were therefore unable to predict in the acute phase whether a patient would be hypertensive in the chronic phase. Hence we concluded that a 24-hour blood pressure measurement one week after the stroke is too early to assess a patient's blood pressure profile. We therefore think that blood pressure in the chronic phase (about 6 weeks after the stroke) should be used to decide whether a patient has hypertension and should be treated.

Chapters 5 and $6 \mathrm{~A}$ report on a study of blood pressure level, variability and nocturnal pressure decline as risk factors for the various stroke subtypes. Furthermore, we compared stroke patients with controls from the same referral area, using 24-hour ambulatory blood pressure measurement. Forty five percent of brain infarct patients reported hypertension, whereas only $17 \%$ of controls did. We found that brain infarct patients in general had higher blood pressure levels, except for daytime levels, than controls. They also showed greater blood pressure variability and lower nocturnal dip than controls. This means that all these aspects of the blood pressure profile represent risk factors for target organ damage such as stroke.

Patients with LACI reported hypertension about as often as patients with territorial infarcts did ( $47 \%$ and $43 \%$ respectively). However, the blood pressure level was higher in $\mathrm{LACl}$ patients. There was no difference in blood pressure variability or nocturnal dip between TERRI and LACI patients. 
We therefore concluded that it is not the presence but the severity of hypertension which determines the brain infarct subtype. Twenty-four hour blood pressure measurement is important because many aspects of the blood pressure profile represent risk factors for stroke.

In chapters 5 and $6 \mathrm{~A}$, we concluded that blood pressure level, but not its variability or diurnal rhythm, determined the development of cerebral small vessel disease. We wanted to investigate whether the blood pressure profile differentially determined the development of one type of small vessel disease. In chapter $6 \mathrm{~B}$, we compare the blood pressure profiles in patients with single lacunar infarcts and patients with multiple lacunar infarcts. We also compared them with patients with territorial infarcts.

We found that DBP and MBP were higher in patients with multiple lacunar infarcts than in patients with single lacunar infarcts or with territorial infarcts. Moreover, SBP variability was greater in patients with multiple lacunar infarcts than in patients with territorial infarcts. The blood pressure profile of patients with single lacunar infarcts differed from that of patients with territorial infarcts only in nighttime SBP variability.

These results provide further evidence supporting the hypothesis that two different lacunar entities exist, which may be caused by the two different subtypes of cerebral small vessel disease described by Fisher. Arteriolosclerosis is associated with higher DBP and MBP levels and SBP variability than microatheromatosis. Microatheromatosis is associated with a blood pressure profile that is very similar to that of large vessel atheromatosis. This supports the theory that these disease processes are similar.

In chapter 6C, we investigate blood pressure profile as a risk factor for WML. We distinguished WML from PVH, because the latter is not associated with vascular risk factors or clinical signs, whereas WML has been associated with arteriolosclerosis.

Both WML and PVH were common in our group of stroke patients. The prevalence of $\mathrm{WMH}$ was $65 \%$, that of $\mathrm{PVH} 95 \%$. We found that nighttime systolic blood pressure was lower in patients with severe WML compared to patients with minor WML. Variability and percentage of dipping of SBP were greater in patients with severe WML than in patients with minor WML. We concluded that blood pressure fluctuations are a risk factor for severe WML. It was also clear, however, that increasing age plays an important role as a risk factor for WML.

Chapter 6D discusses the relationship between blood pressure profile and stroke lesion site. 
We found that $52 \%$ of or patients with right-sided cortical infarcts had a nocturnal rise in blood pressure in the acute phase of stroke. We also found a transient decrease in the nocturnal dip and the percentage of dipping in patients with right-sided cortical infarcts. This group of patients need to be closely monitored in a stroke unit in the acute phase of stroke, because these changes in blood pressure profile may lead to serious complications.

In summary, we conclude that blood pressure measured in the chronic phase after stroke reflects pre-stroke pressure, but that blood pressure in the acute phase of stroke does not predict hypertension in the chronic phase. Temporary changes in nocturnal blood pressure decline occur in patients with right-sided cortical infarcts. The blood pressure profile of patients with microatheromatosis is similar to that of patients with macroatheromatosis. We found further evidence for the existence of two distinct lacunar entities, since blood pressure was higher in patients with multiple LACls than in those with a single LACI.

We recommend blood pressure management by at least one 24-hour ambulatory blood pressure measurement to monitor nocturnal pressure decline and blood pressure variability, because these aspects of the blood pressure profile are risk factors for TOD. Also, further research should be done to find medication that specifically influences blood pressure variability and nocturnal blood pressure decline. Patients with right-sided cortical infarcts should be monitored in the acute phase of stroke. 


\section{SAMENVATTING}


Hoewel het een algemeen geaccepteerd feit is dat hypertensie de belangrijkste risicofactor is voor het krijgen van een ischemisch herseninfarct, is de relatie tussen bloeddrukprofiel, infarct-subtype en cerebrale vaataandoening nog nauwelijks onderzocht.

Toch is het belangrijk om deze relatie te onderzoeken, vanwege de mogelijke consequenties voor preventie en voor de behandeling van de individuele patiënt. Dit moet worden gezien tegen de achtergrond van de vergrijzende wereldbevolking, die in toenemende mate een westerse levensstijl heeft. In de nabije toekomst wordt dan ook een toename in de prevalentie van hypertensie en herseninfarcten verwacht. Het kan echter voorkomen dat een patiënt niet weet dat hij hypertensie heeft totdat complicaties zoals een ischemisch herseninfarct optreden. In dat geval is de bloeddruk na het herseninfarct de enige informatie die voorhanden is. Aangezien echter de bloeddruk na het herseninfarct kan stijgen, is het de vraag of bloeddruk in de acute fase na een herseninfarct gebruikt mag worden om vast te stellen of een patiënt hypertensie heeft en of er een behandeling gestart moet worden.

In dit onderzoek is daarom een vergelijking gemaakt tussen de bloeddruk voor en na het herseninfarct, gemeten met een manometer, en is voorts onderzocht of de in de acute fase door middel van 24-uurs ambulante meting bepaalde bloeddruk de bloeddruk in de chronische fase na een herseninfarct kan voorspellen.

Er bestaan verschillende typen cerebrale vaataandoening die ischemische herseninfarcten veroorzaken. Als de grote hersenarteriën zijn aangedaan (large vessel disease of LVD) ontstaat een territoriaal herseninfarct (TERRI). Betreft het de kleine perforerende hersenarteriën (small vessel disease of SVD), dan ontstaat een lacunair infarct (LACI). Eerder onderzoek heeft aangetoond dat er twee lacunaire entiteiten kunnen worden onderscheiden, die elk door een specifiek type aandoening van de kleine hersenarteriën zouden kunnen worden veroorzaakt.

Microatheromatose is een proces waarbij een kleine hersenarterie bij het punt van aftakking wordt afgesloten door een atherosclerotische plaque. Dit proces lijkt sterk op atheromatose van de grote hersenarteriën en het resultaat is één enkel lacunair infarct. Dit proces wordt onderscheiden van arteriolosclerose, een gegeneraliseerde aandoening van de kleine hersenarteriën waarbij segmentale destructie van de vaatwand plaatsvindt en hyaline wordt afgezet in de wand van de penetrerende arteriën, waardoor meervoudige lacunaire infarcten en wittestofafwijkingen kunnen ontstaan. 
Arteriolosclerose wordt met name in verband gebracht met hypertensie, terwijl de risicofactoren voor microatheromatose vrijwel overeenkomen met die voor atheromatose van de grote vaten.

Het is moeilijk om onderzoek te doen naar bloeddruk als risicofactor voor een bepaalde cerebrale vaataandoening, omdat vooral LACl's relatief zelden fataal zijn en er dus weinig autopsies worden verricht. Daarom moeten we gebruik maken van indirecte methoden. Wij hebben daarom door middel van 24-uurs ambulante meting het bloeddrukprofiel van patiënten met een herseninfarct vergeleken met dat van een controlegroep, en ook het profiel van patiënten met een TERRI met dat van patiënten met een $\mathrm{LACl}$. Daarnaast hebben we patiënten met meervoudige LACl's vergeleken met patiënten met één enkel $\mathrm{LACl}$, alsook de beide lacunaire subtypen onderling. Voorts hebben we het bloeddrukprofiel, bepaald door middel van 24-uurs ambulante meting, bestudeerd als risicofactor voor de ernst van de eventuele wittestoflaesies op MRI-scans. Als laatste bestudeerden wij de veranderingen in het bloeddrukprofiel die optreden na een herseninfarct.

In hoofdstuk 3 wordt de vraag besproken of de bloeddruk die in de chronische fase (ongeveer 6 weken) na het optreden van een herseninfarct door middel van manometrie gemeten wordt, een betrouwbare afspiegeling is van de bloeddruk die vóór het herseninfarct gemeten is. Het bleek dat de post-CVA bloeddruk inderdaad een betrouwbare afspiegeling is van de pre-CVA bloeddruk. Wij concludeerden daarom dat bloeddrukmetingen na het optreden van een hereninfarct gebruikt kunnen worden bij het onderzoek naar bloeddruk als causale factor voor het herseninfarct van een patiënt. In ons verdere onderzoek gebruikten wij de post-CVA metingen omdat de pre-CVA metingen niet altijd voorhanden waren.

Hoofdstuk 4 beschrijft de resultaten van een onderzoek waarbij werd bekeken of 24-uurs ambulante bloeddrukmetingen in de acute fase (ongeveer 1 week) na een herseninfarct de bloeddruk in de chronische fase kunnen voorspellen.

Er bleek een goede correlatie te bestaan tussen de bloeddruk in de acute en de chronische fase (correlatie-coëfficiënten van $0.6-0.8$ ) maar de predictie-intervallen waren groot. Daarom kon in de acute fase van het herseninfarct niet worden voorspeld of een patiënt in de chronische fase hypertensief zou zijn. Hieruit concludeerden wij dat 24-uurs bloeddrukmeting een week na het optreden van een herseninfarct te vroeg is om het bloeddrukprofiel van een patiënt te bepalen. Wij zijn daarom van mening dat de bloeddruk in de chronische fase (ongeveer 6 weken) na het herseninfarct gebruikt moet worden om te besluiten of een patiënt hypertensie heeft en behandeld moet worden. 
In hoofdstuk 5 en $6 \mathrm{~A}$ worden de resultaten besproken van een onderzoek naar de hoogte en variabiliteit van de bloeddruk en de nachtelijke daling (dip) als risicofactoren voor de verschillende infarct-subtypen. Daarbij werden de herseninfarctpatiënten ook vergeleken met een controlegroep uit hetzelfde geografische gebied. We gebruikten hiervoor 24-uurs ambulante bloeddrukmeting.

Vijfenveertig procent van de patiënten met een herseninfarct, tegen slechts $17 \%$ van de controlegroep, hadden hypertensie in de voorgeschiedenis. Het bleek dat de groep infarctpatiënten als geheel een hogere bloeddruk vertoonde dan de controlegroep, behalve overdag. Zij hadden ook een grotere bloeddrukvariabiliteit en een minder sterke nachtelijke daling. Dit betekent dat al deze aspecten van het bloeddrukprofiel risicofactoren vormen voor eindorgaanschade zoals een ischemisch herseninfarct.

Patiënten met een $\mathrm{LACl}$ hadden even vaak hypertensie in de voorgeschiedenis als patiënten met een territoriaal infarct (respectievelijk $47 \%$ en $43 \%$ ). De bloeddruk was echter het hoogst bij patiënten met een $\mathrm{LACl}$.

Wij concludeerden dat hypertensie en een hoge nachtelijke en 24-uurs bloeddruk risicofactoren zijn voor het krijgen van een ischemisch herseninfarct in het algemeen. Verder verhoogt hoge bloeddruk, maar niet het hebben van hypertensie, de kans op het krijgen van een LACI.

In hoofdstuk 5 en 6 A concludeerden wij dat het ontstaan van SVD werd bepaald door de hoogte van de bloeddruk, maar niet door de bloeddrukvariabiliteit of het percentage nachtelijke daling. Wij wilden onderzoeken of het bloeddrukprofiel ook invloed had op het type SVD.

In het onderzoek waarvan verslag wordt uitgebracht in hoofdstuk 6B bestudeerden wij daarom het bloeddrukprofiel van patiënten met één enkel $\mathrm{LACl}$ in vergelijk met patiënten met meervoudige LACl's. Beide groepen werden vergeleken met patiënten met een TERRI.

DBP en MBP bleken hoger te zijn bij patiënten met meervoudige LACl's in vergelijking met patiënten met één enkel $\mathrm{LACl}$ en patiënten met een TERRI. Daarbij komt dat de variabiliteit van de SBP hoger was bij patiënten met meervoudige LACl's dan bij patiënten met een TERRI. Het bloeddrukprofiel van patiënten met één enkel $\mathrm{LACl}$ verschilde alleen van dat van TERRI-patiënten in de nachtelijke SBP-variabiliteit.

Onze resultaten ondersteunen de hypothese dat er twee verschillende lacunaire entiteiten bestaan, die elk worden veroorzaakt door een verschillend subtype SVD, zoals beschreven door Fisher. Arteriolosclerose gaat gepaard met een hogere DBP en MBP, en een grotere SBP-variabiliteit, dan microatheromatose. Microatheromatose 
gaat gepaard met een bloeddrukprofiel dat sterk lijkt op dat van LVD. Dit ondersteunt de theorie dat dit vergelijkbare aandoeningen zijn.

Hoofdstuk $6 \mathrm{C}$ behandelt het bloeddrukprofiel als risicofactor voor wittestoflaesies (WML's). Wij hebben onderscheid gemaakt tussen WML's en periventriculaire hyperintense laesies (PVH's) omdat de laatsten niet geassocieerd zijn met vasculaire risicofactoren of klinische verschijnselen, terwijl WML's in verband gebracht zijn met arteriolosclerose.

Onze hypothese was dat verhoogde bloeddruk, bloeddrukvariabiliteit en nachtelijke dip risicofactoren zijn voor de toename van het aantal WML's. Wij verwachtten geen verband tussen de veel voorkomende PVH's en de bloeddrukparameters.

WML's en PVH's kwamen allebei veel voor in onze groep herseninfarctpatiënten. De prevalentie van PVH's was $65 \%$, die van PVH's 95. Patiënten met uitgebreide WML's bleken een lagere nachtelijke systolische bloeddruk te hebben dan patiënten met geringe WML's. De bloeddrukvariabiliteit en het percentage nachtelijke daling van de SBP waren hoger bij patiënten met uitgebreide WML's dan bij patiënten met geringe WML's. Wij concludeerden dat bloeddrukfluctuaties een belangrijke risicofactor zijn voor uitgebreide WML's. Het was ook duidelijk dat de leeftijd een belangrijke risicofactor was.

In hoofdstuk 6D wordt de relatie besproken tussen het bloeddrukprofiel en de locatie van het herseninfarct. Tweeënvijftig procent van de patiënten met een rechtszijdig corticaal infarct vertoonde een nachtelijke bloeddrukstijging in de acute fase na het herseninfarct. Wij vonden ook een voorbijgaande vermindering van de dip en het percentage nachtelijke bloeddrukdaling bij patiënten met een rechtszijdig corticaal infarct. Deze groep patiënten heeft bewaking nodig in een stroke unit in het acute stadium na het herseninfarct omdat de veranderingen in het bloeddrukprofiel kunnen leiden tot ernstige complicaties.

Samenvattend luiden onze voornaamste conclusies als volgt. De bloeddruk die in de chronische fase na een herseninfarct gemeten wordt, vormt een goede afspiegeling van de bloeddruk vóór het herseninfarct. De bloeddruk in de acute fase na een herseninfarct voorspelt de bloeddruk in de chronische fase niet. Er treedt een voorbijgaande verandering op in de nachtelijke bloeddrukdaling bij patiënten met een rechtszijdig corticaal infarct. Het bloeddrukprofiel van patiënten met microatheromatose lijkt op dat van patiënten met macroatheromatose. Wij vonden aanvullend bewijsmateriaal voor de theorie dat er twee afzonderlijke lacunaire entiteiten bestaan, omdat patiënten met 
meervoudige LACl's een hogere bloeddruk bleken te hebben dan patiënten met een enkel LACI.

Wij stellen tenminste één 24-uurs ambulante bloeddrukmeting voor om de nachtelijke bloeddrukdaling en bloeddrukvariabiliteit in kaart te brengen, omdat deze aspecten van het bloeddrukprofiel risicofactoren zijn voor eindorgaanschade. Ook zou verder onderzoek gedaan moeten worden naar middelen die specifiek de bloeddrukvariabiliteit en de nachtelijke bloeddrukdaling beïnvloeden. Patiënten met een rechtszijdig corticaal infarct hebben in het acute stadium na een herseninfarct bewaking nodig in een stroke unit. 


\section{REFERENCES}

1 MacMahon S, Peto R, Cutler J, et al. Blood pressure, stroke and coronary heart disease Part 1. Lancet 1990; 335: 765- 74.

2 Mensah GA, Pappas T, Koren MJ, et al. Comparison of classification of the severity of hypertension by blood pressure level and by World Health Organisation criteria in the prediction of concurrent cardiac abnormalities and subsequent complications in essential hypertension. Journal of Hypertension 1993; 11: 1429-40.

3 Bennet, NE. Hypertension in the elderly. Lancet 1994; 344: 447- 49.

4 Wolf P A, Belanger A J, D' Agostino R B. Quantifying stroke risk factors and potentials for risk reduction. Cerebrovascular Diseases 1993; 3 (suppl 1): 7- 14.

5 Black HR. New concepts in hypertension: Focus on the elderly. American Heart Journal 1998; 135: S2- S7.

6 Nielsen W B, Vestbo $\mathrm{J}$ and Jensen G B. Isolated systlolic hypertension as a major risk factor for stroke and myocardial infarction and an unexploited source of cardiovascular prevention: a prospective population- based study. Journal of Human Hypertension 1995; 9: 175- 80.

7 Kannel W B.Framingham study insights into hypertensive risk of cardiovascular disease. Hypertension Research 1995; 3: 181- 96.

8 Boiten J, Lodder J . Epidemiologie. In: Cerebro Vasculaire aandoeningen. Limburg M, Hijdra A, Cools H (eds): 1999; ch 2.

9 Konings- Dalstra J A A and Reitsma J B. Hart- en vaatziekten in Nederland 1999, cijfers over ziekte en sterfte. Nederlandse hartstichting 1999 den Haag.

10 Guidelines subcommittee WHO. 1999 World Health organization International Society of Hypertension Guidelines for the management of hypertension. Journal of Hypertension 1999; 17: 151- 83.

11 Lemesle $\mathrm{M}$, Milan $\mathrm{C}$ and Faivre $\mathrm{J}$ et al. Incidence trends of ischemic stroke and transient ischemic attacks in a well- defined French population from 1985 through 1994. Stroke 1999; 30: 371- 77.

12 Parati G, Pomidossi G, Albini F et al. Relationship of 24- hour blood pressure mean and variability to severity of target- organ damage in hypertension. Journal of Hypertension 1987; 5: 93- 98.

13 Shimada K, Kawamoto A, Matsubayashi K, Ozawa T. Silent cerebrovascular disease in the elderly. Correlation with ambulatory pressure. Hypertension 1990; 16: 692- 99.

14 Ohkubo T, Imai Y, Ysuji I et al. Prediction of mortality by ambulatory blood pressure monitoring versus screening blood pressure measurements: a pilot study in Ohasama. Journal of Hypertension 1997; 15: 357- 64.

15 Mancia G, Sega R, Bravi C et al. Ambulatory blood pressure normaltity: results from the PAMELA study. Journal of Hypertension 1995; 13: 1377 90 . 
16 Devereux RB and Pickering T G. Relationship between the level, pattern and variability of ambulatory blood pressure and target organ damage in hypertension. Journal of Hypertension 1991; 9 (supp 8): S34- S38.

17 Harper G, Fotherby M D Panayiotou B J, Castleden C M, Pottere J F et al. The changes in blood pressure after acute stroke: abolishing the 'white coat effect' with 24-hour ambulatory monitoring. Journal of Internal Medicine 1994; 235: 343- 46.

18 Punzi H. Why ambulatory blood pressure monitoring ? American Journal of Health-Systems and Pharmacology 1998; 55 supp 3: S12-6.

19 Fisher C M. The arterial lesions underlying lacunes. Acta Neuropathologica 1969; 12: 1- 15.

20 Fisher C M. Lacunar strokes and infacts: a review. Neurology 1982; 32: 871- 76.

21 Fisher CM. Lacunes: small, deep cerebral infarcts. Neurology 1965; 15: 774- 84.

22 Fisher CM. Lacunar infarcts- a review. Cerebrovascular Diseases 1991; 1 : 311- 20.

23 Mast $\mathrm{H}$, Thompson JLP, Lee, SH et al. Hypertension and diabetes mellitus as determinants of multiple lacunar infarcts. Stroke 1995; 26: 30-33.

24 Boiten J, Lodder J. Lacunar infarcts. Pathogenesis and validity of the clinical syndromes. Stroke 1991; 22: 1374- 78.

25 Boiten J, Luijckx G J, Kessels F and Lodder J. Risk factors for lacunes. Neurology 1996; 47: 1109- 10.

26 Boiten J, Lodder J, Kessels F. Two clinically distinct lacunar infarct entities? A hypothesis. Stroke 1993; 24: 652- 56.

27 Sander D, Klingelhofer. Changes of circadian blood pressure patterns after hemodynamic and thromboembolic stroke. Stroke 1994; 25: 173037.

28 Yamahoto Y, Akiguchi I, Oiwa K, Tsuda H. Circadian blood pressure changes in various forms of cerebrovascular disease. Stroke 1990; 21: Supp I, 09-12.

29 Talman WT . Cardiovascular regulation and lesions of the central nervous system. Annals of Neurology 1985; 18: 1-12.

30 Giubilei F, Strano S, Lino S et al. Autonomic nervous activity during sleep in middle cerebral artery infarction. Cerebrovascular Diseases 1998; 8: 118- 23.

31 Chechetto D F, Hachinski V eds. Neurocardiology. 1997; Bailliere's.

32 Yamamoto $\mathrm{Y}$, Akiguchi I, Oiwa $\mathrm{K}$ et al. Diminished nocturnal blood pressure decline and lesion site in cerebrovascular disease. Stroke 1995; 26: 829- 33 .

33 The sixth report of the Joint National Committee on Detection, Evaluation and Treatment of High Blood Pressure. Archives of Internal Medicine 1997; 157: 2413- 45.

34 Pickering TG. Blood pressure measurement and the detection of hypertension. Lancet 199; 344: 31- 35. 
35 Black HR, Yi JY. A new classification scheme for hypertension based on relative and absolute risk with implications for treatment and reimbursement. Hypertension 1996; 28: 719- 24.

36 Devereux R B, James G D, Pickering T G. What is normal blood pressure? Comparison of ambulatory pressure level and variability in patients with normal or abnormal left ventricular geometry. American Journal of Hypertension 1993; 6: 211S- 215S.

37 Staessen J A, Fagard $\mathrm{R} \mathrm{H}$, Lijnen $\mathrm{P} J$ et al. Mean and range of ambulatory pressure in normotensive subjects from a meta- analysis of 23 studies. American Journal of Cardiology 1991; 67: 723- 27.

38 Thijs L, Staessen J, Celis $\mathrm{H}$ et al. Reference values for self- recorded blood pressure. A meta- analysis of summary data. Archives of Internal Medicine 1998; 158: 481- 88.

39 Burt V L, Cutler J A, Higgins $M$ et al. Trends in prevalence, awareness, treatment and control of hypertension in the adult US population. Hypertension 1995; 26: 60- 69.

40 Van Boxtel M P J. Physical health, vascular risk factors, and age- related cognitive decline. Thesis 1997.

41 Van Boxtel M P J, Gaillard C, van Es P N et al. Repeated autonomic versus ambulatory blood pressure measurement: the effects of age and sex in a normal ageing population. Journal of Hypertension 1996; 14: 3140.

42 Okkes I M, Lamberts $\mathrm{H}$. Verschillende frequentiecijfers van aandoeningen bij gezondheidsenquete en huisartsregistraties. Nederlands Tijdschrift voor Geneeskunde 1997; 141: 634- 38.

43 Okkes I M, Veltman M T M and Lamberts H. Daalde hypertensie in Nederland tussen 1973 en 1993 ? Nederlands Tijdschrift voor Geneeskunde 1997; 141: 491- 92.

44 Whelton PK. Epidemiology in hypertension. Lancet 1994; 344: 101- 06.

45 Watson RDS, Stallard, TJ, Flinn RM et al. Factors determining direct arterial pressure and its variability in man. Hypertension 1980; 2: 333- 41.

46 Burke V, Beilin L J, Grosskopf et al. Association of lifestyle and personality characteristics with blood pressure and hypertension. Journal of Clinical Epidemiology 1992; 45: 1061- 70.

47 Simons L A, McCallum J, Friedlander $Y$ and Simons J. Risk factors for ischaemic stroke Dubbo study of the elderly. Stroke 1998; 29: 1341- 46.

48 Marang P J, Gunning L J. Variation between studies in reported relative risks associated with hypertension: Time trends and other explanatory variables. American Journal of Public Health 1998; 88: 618-22.

49 Kornitzer M, Dramaix M and Backer $G$ de. Epidemiology of risk factors for hypertension. Drugs 1999; 57: 695- 712.

50 Whisnant J P, Wiebers D O, O'Falon W M et al. A population- based model of risk factors for ischaemic stroke: Rochester, Minnesota. Neurology 1996; 47: 1420- 28. 
51 Johansson BB. Hypertension mechanisms causing stroke. Clinical and Experimental Pharmacology and Physiology 1999; 26: 563- 65.

52 Ferrara L A, Guida L, Pasanisi F et al. Isolated office hypertension and end- organ damage. Journal of Hypertension 1997; 15: 979- 85.

53 Sutton- Tyrrell K, Alcorn H G, Herzog $\mathrm{H}$ et al. Morbidity, mortality and antihypertensive treatment effects by extent of atherosclerosis in older adults with isolated systolic hypertension. Stroke 1995; 26: 1319- 24.

54 D' Agostino Wolf P A, Belanger A J, Kannel W B. Stroke risk profile: adjustment for antihypertensive medication. Stroke 1994; 25: 40- 43.

55 Howard G, Manolio T A, Burke G L et al. Does the association of risk factors and atherosclerosis change with age? An analysis of the combined ARIC and CHS cohorts. Stroke 1997; 28: 1693- 1701.

56 Sutton- Tyrrell K, Alcorn H G, Wolfson S K Jr et al. Predictors of carotid stenosis in older adults with and without isolated systolic hypertension. Stroke 1993; 24: 1333- 40.

57 Alli $\mathrm{C}$, Avancini $\mathrm{F}$, Bettelli $\mathrm{G}$ et al. The long- term prognostic value of repeated blood pressure measurements in the elderly. Archives of Internal Medicine 1999; 159: 1205- 12.

58 Britton M, Carlsson A, De Faire U. Blood pressure course in patients with acute stroke and matched controls. Stroke 1986; 17: 861- 64.

59 Kario K, Matsuo T, Kobayashi H, et al. Nocturnal fall in blood pressure and silent cerebrovascular damage in elderly hypertensive patients. Advanced silent cerebrovascular damage in extreme dippers. Hypertension 1996; 27 : 130- 35.

60 Tohgi H, Chiba K, Kimura $M$ et al. Twenty- four hour variation of blood pressure in vascular dementia of the Binswanger type. Stroke 1991; 22: 603- 08.

61 Mancia G. Blood pressure variability: mechanisms and clinical significance. Journal of Cardiovascular Pharmacology 1990; 16: supp 6 S1-S6.

62 Frattola A, Parati G, Cuspidi C et al. Prognostic value of 24- hr blood pressure variability. Journal of Hypertension 1993; 11: 1133- 37.

63 Palatini P, Penzo M, Racioppa A et al. Clinical significance of nighttime blood pressure and of daytime blood pressure variability. Archives of Internal Medicine 1992; 152: 1855- 60.

64 Kario K, Matsuo T, Kobayashi $\mathrm{H}$ et al. Nocturnal fall in blood pressure and silent cerebrovascular damage in elderly hypertensive patients. Advanced silent cerebrovascular damage in extreme dippers. Hypertension 1996; 27: 130-35.

65 Davis B R, Vogt T, Frost P H et al. Risk factors for stroke and type of stroke in persons with isolated systolic hypertension. Stroke 1998; 29: 1333- 40.

66 Collins R, Peto R, MacMahon S et al. Blood pressure, stroke and coronary heart disease Part 2. Lancet 1990; 335: 827- 38. 
67 Hypertension Detection and Follow-up Program Coopreative Group. Fiveyear findings of the hypertension detection and follow-up program. Journal of the American Medical Association 1982; 247: 633- 38.

68 Sutton- Tyrrell K, Wolfson SK, Kuller LH. Blood pressure treatment slows the progression of carotid stenosis in patients with isolated systolic hypertension. Stroke 1994; 25: 44- 50.

69 Lever A F, Ramsay L E. Treatment of hypertension in the elderly. Journal of Hypertension 1995; 13: 571- 79.

70 Staessen J, Fagart R, Thijs L et al. Randomised double- blind comparison of placebo and active treatment for older patients with isolated systolic hypertension. Lancet 1997; 350: 757- 64.

71 Curb J D, Pressel S L, Cutler et al. Effect of diuretic- based antihypertensive treatment on cardiovascular disease risk in older diabetic patients with isolated systolic hypertension. Journal of the American Medical Association 1996; 276: 1886- 92.

72 SHEP Cooperative research group. Prevention of stroke by antihypertensive drug treatment in older persons with isolated systolic hypertension. Journal of the American Medical Association 1991; 265: 3255- 64.

73 Moye L A, Davis B R and Hawkins M. Conclusions and implications of the systolic hypertension in the elderly program. Clinical and Experimental Hypertension 1993; 15: 911-24.

74 Klungel $\mathrm{OH}$, Stricker BHC, Paes AHP et al. Excess stroke among hypertensive men and women attributable to undertreatment of hypertension. Stroke 1999: 30: 1312- 18.

75 Merlo J, Lindberg G, Lindblad $\mathrm{U}$ et al. Utilization of cardiovascular drugs (blood pressure lowering drugs, lipid lowering drugs and nitrates) and mortality from ischaemic heart disease and stroke. European Journal of Clinical Pharmacology 1999; 55: 69- 76.

76 Irie $\mathrm{K}$, Yamaguchi $\mathrm{T}$, Minematsu $\mathrm{K}$ et al. The $\mathrm{J}$ - Curve phenomenon in stroke recurrence. Stroke 1993; 24: 1844-49.

77 Millar- Craig MW, Bishop CN, Raftery EB. Circadian variation of blood pressure. Lancet 1978; 328: 795- 97.

78 Staessen J, Bulpitt CJ, O'Brien E et al. The diurnal blood pressure profile. The American Journal of Hypertension 1992; 5: 386- 92.

79 Mancia G, Parati G, Pomidossi G et al. Arterial baroreflexes and blood pressure and heart rate variability in humans. Hypertension 1986; 8: 14753.

80 Kobari M, Meyer J C, Ichijo M . Leuko- araiosis, cerebral atrophy and cerebral perfusion in normal aging. Archives of Neurology 1990; 47: 16165.

81 Yoon B J, Morillo C A, Cechetto D F et al. Cerebral lateralisation in cardiac autonomic control. Archives of Neurology 1997; 54: 741- 44. 
82 Hachinski V C, Oppenheimer S M, Wilson $\mathrm{J}$ X et al. Asymmetry of sympathetic consequences of experimental stroke. Stroke 1992; 49: 697702.

83 Korpelainen JT, Sotaniemi KA, Suominen K et al. Cardiovascular autonomic reflexes in brain infarction. Stroke 1994; 25: 787- 92.

84 Mancia G, Casadei A, Gropelli et al. 24-Hour Blood pressure monitoring in hypertension. Journal of Cardiovascular Pharmacology 1991;17: supp 1 S1 - S3.

85 Grassi G, Cattaneo B M, Seravalle G. Baroreflex control of sympathetic nerve activity in essential and secondary hypertension. Hypertension 1998; 31 [part 1]: 68- 72.

86 Floras, JS, Hassan MO, Jones JV, et al. Factors influencing blood pressure and heart rate variability in hypertensive humans. Hypertension 1988; 11: 273- 81.

87 Veerman DP, Imholz BPM, Wieling W, et al. Effects of aging on blood pressure variability in resting conditions. Hypertension 1994; 24: 120- 30.

88 Staessen J, Thijs L, Fagard R et al. Predicting cardiavascular risk using conventional vs ambulatory blood pressure in older patients with systolic hypertension. Journal of the American Medical Association 1999; 282: 539- 46.

89 Mallion J-M, Baguet J-P, Siche J-P et al. Clinical value of ambulatory blood pressure monitoring. Journal of Hypertension 1999; 17: 585- 95.

90 Nunes JP, do Sameiro Faria M, Polonia, JJ. Acute ischaemic stroke during ambulatory blood pressure monitoring. Lancet 1992; 339: 1113- 14.

91 Lip GYH, Zarifis J, Farooqui IS et al. Ambularory blood pressure monitoring in acute stroke. Stroke 1997; 28: 31- 35.

92 Lip GIH, Gibbs CR and Beevers, DG. Ambuatory blood pressure monitoring and stroke. More questions than answers. Stroke 1998; 29: 1495- 97.

93 Kario $\mathrm{K}$ and Shimara K. Change in diurnal blood pressure rhythm due to small lacunar infarct. Lancet 1994; 344: 200.

94 Paulson O, Strandgaard S and Edvinsson. Cerebral autoregulation. Cerebrovascular and Brain Metabolism Reviews 1990; 2: 161- 92.

95 Waldemar G, Hasselbach S G, Andersen A R et al. ${ }^{99 m}$ Tc-d, I- HMPAO and SPECT of the brain in normal aging. Journal of Cerebral Blood Flow and Metabolism 1991; 11: 508- 21.

96 Catafau M, Lomena FJ, Pavia J et al. Regional cerebral blood flow pattern in normal young and aged volunteers: a ${ }^{99 \mathrm{~m}} \mathrm{Tc}$ HMPAO SPET study. European Journal of Nuclear Medicine 1996; 23: 1329- 37.

97 Mozley PD, Sadek A, Alavi A et al. Effects of aging on the cerebral distribution of technetium- $99 \mathrm{~m}$ hexamethylpropylene amine oxime in healthy humans. European Journal of Nuclear Medicine 1997; 24: 754- 61.

98 Naritomi H, Meyer J S, Sakai F et al. Effects of advancing age on regional cerebral blood flow. Studies in normal subjects with risk factors for atherothrombotic stroke. Archives of Neurology 1979; 36: 410- 16. 
99 Claus J, Breteler MMB, Hasan D et al. Vascular risk factors, atherosclerosis, cerebral white matter lesions and cerebral perfusion in a population based study. European Journal of Nuclear Medicine 1996; 23: 675- 82.

100 Nobili F, Rodriguez G, Marceno S et al. Regional cerebral blood flow in chronic hypertension. A correlative study. Stroke 1993; 24: 1148-53.

101 Hatazawa J, Shimosegawa E, Satoh T et al. Subcortical hypoperfusion associated with asymptomatic white matter lesions on magnetic resonance imaging. Stroke 1997; 28: 1944- 47.

102 Semplicini A, Meneghetti G, Chierichetti F et al. SPECT evaluation of cerebral perfusion in uncomplicated essential hypertensives and effects of enelapril. Cerebrovascular Diseases 1994; 4: 354- 58.

103 Hademenos G J, Massoud TF. Biophysical mechanisms of stroke. Stroke 1997; 28: 2067- 77.

104 Meyer JS, Rogers R, Mortel KF. Prospective analysis of long term control of mild hypertension on cerebral blood flow. Stroke 1985; 16: 985- 89.

105 Mochzuki Y, Oishi M, Takasu T . Cerebral blood flow in single and multiple lacunar infarctions. Stroke 1997; 28: 1458- 60.

106 Kobayashi S, Okada K and Yamashita K . Incidence of silent lacunar lesion in normal adults and its relation to cerebral blood flow and risk factors. Stroke 1991; 22: 1379-83.

107 De Roo M, Mortelmans P, Devos P et al. Clinical experience with Tc- 99m HMPAO high resolution SPECT of the brain in patients with cerebrovascular accidents. European Journal of Nuclear Medicine 1989; 15: 9- 15.

108 Raynaud C, Rancurel G, Tzourio $\mathrm{N}$ et al. SPECT analysis of recent cerebral infarction. Stroke 1989; 20: 192- 204.

109 Kaufmann A M, Firlik A D, Fukui M B et al. Ischemic core and penumbra in human stroke. Stroke 1999; 30: 93- 99.

110 Perani D, Di Piero V, Lucignani G et al. Remote effects of subcortical cerebrovascular lesions: a SPECT cerebral perfusion study. Journal of Cerebral Blood Flow and Metabolism 1988; 8: 560- 67.

111 Sakashita $\mathrm{Y}$, Matsuda $\mathrm{H}$, Kakuda $\mathrm{K}$ and Takamori M. Hypoperfusion and vasoreactivity in the thalamus and cerebellum after stroke. Stroke 1993; 24: 84- 87.

112 Andrews R J . Transhemispheric diaschisis. A review and comment. Stroke 1991; 22: 943- 49.

113 Moretti J L, Defer G Cinotti L et al. "Luxury perfusion" with ${ }^{99 m} \mathrm{Tc}$ - HMPAO and ${ }^{123}$ I- IMP SPECT imaging during the subacute phase of stroke. European Journal of Nuclear Medicine 1990; 16: 17- 27.

114 Malmgren R, Warlow C, Bamford J et al. Geographical and secular trends in stroke incidence. Lancet 1987; 334: 1196- 1200.

115 Herman B, Leyten A C M, Luijk J H van et al. Epidemiology of stroke in Tilburg, the Netherlands. The population- based stroke incidence register: 
2. Incidence initial clinical picture and medical care, and three week case fatality. Stroke 1982; 13: 629-34.

116 Bamford J, Sandercock $\mathrm{P}$, Dennis $\mathrm{M}$ et al. A prospective study of acute cerebrovascular disease in the community: the Oxfordshire Community Stroke Project- 1981- 1986. Incidence, case fatality rates and overall outcome at one year of cerebral infarction, primary intracerebral haemorrhage and subarachnoid haemorrhage. Journal of Neurology, Neurosurgery and Psychiatry 1990; 53: 16- 22.

117 Bonita R. Epidemiology of stroke. Lancet 1992; 339: 342- 44.

118 Vemmos $\mathrm{K} \mathrm{N}$, Bots M L, Tsibouris $\mathrm{P} \mathrm{K}$ et al. Stroke incidence and case fatality in southern Greece. Stroke 1999; 30: 363-70.

119 Rossum T M van, Mheen H van, Breteler, M M B et al. Socioeconomic differences in stroke among Dutch elderly women. Stroke 1999; 30: 35762.

120 Schulte B P M, Gijn van. Het cerebrovasculaire accident. In: Epidemiologie van ziekten in Nederland. Grobbee D E , Hofman A (eds): 1989; ch 7.

121 Looman S J, Hofman A et al. Beroerte bij ouderen: prevalentie en opnamefrequentie; het ERGO onderzoek. Nederlands Tijdschrift voor Geneeskunde 1996;140: 312- 16.

122 The European ad- hoc consensus group. Optimising intensive care in stroke: a European perspective. Cerebrovascular Diseases 1997; 7: 113- 28.

123 Warlow CP, Dennis MS, van Gijn J, et al. in: Stroke: a practical guide to management.1996: Blackwell Science Itd; Ch 6 pp 190- 258.

124 Wolf P A, D'Agositino R B, O' Neal et al. Secular trends in stroke incidence and mortality. Stroke 1992; 23: 1551- 55.

125 Carlsson A, Britton M. Blood pressure after stroke. A one year follow-up study. Stroke 1993; 24: 195- 99.

126 Fujishima S, Abe I, Odaka Y, Saku Y et al. Serial changes in blood pressure and neurohormone levels after the onset of lacunar stroke. Angiology 1996; 47: 579- 87.

127 Jansen PAF, Schulte BPM Poels EFJ, Gribnau FWJ. Course of blood pressure after cerebral infarction and transient ischaemic attack. Clinical Neurology and Neurosurgery 1987; 89: 243- 46.

128 Wallace JD, Levy LL. Blood pressure after stroke. Journal of the American Medical Association 1981; 246: 2177- 80.

129 Morfis L, Schwartz R S, Poulos R et al. Blood pressure changes in acute cerebral infarction and hemorrhage. Stroke 1997; 28: 1401- 05.

130 Kukla C, Sander D, Schwarze J et al. Changes of circadian blood pressure patterns are associated with the occurrence of lacunar infarction. Archives of Neurology 1998; 55: 683- 88.

131 Harper G, Castleden C M, Potter J F. Factors affecting changes in blood pressure after acute stroke. Stroke 1994; 25: 1726- 29. 
132 Morfis L, Schwartz R, Lykos D et al. 24-hour ambulatory blood pressure profiles in the acute phase of stroke. Clinical and Experimental Pharmacology and Physiology 1995; 22: 775-77.

133 Osaki Y, Matsubayashi K, Okumiya et al. Does surge in blood pressure precede or follow stroke? Lancet 1996; 347: 472- 73.

134 Elliott W J. Circadian variation in the timing of stroke onset. A metaanalysis. Stroke 1998; 29: 992- 96.

135 Lago A, Geffner D, Tembl J et al. Circadian variation in ischaemic stroke. A hospital- based study. Stroke: 1998; 29: 1873- 75.

136 Kelly- Hayes M, Wolf P A, Kase C S et al. Temporal patterns in stroke onset. The Framingham study. Stroke 1995; 26: 1343- 47.

137 Robinson T, Potter J. Cardiopulmonary and arterial baroreflex- mediated control of forearm vasomotor tone is impaired after acute stroke. Stroke 1997; 28: 2357- 62.

138 Robinson T G, James M, Youde J et al Cardiac. Baroreceptor sensitivity is impaired after acute stroke. Stroke 1997; 28: 1671- 76.

139 Nakamura K, Oita J, Yamaguchi T. Nocturnal blood pressure dip in stroke survivors. Stroke 1995; 26: 1373- 78.

140 Dawson SL, Evans S N, Manktelow BN et al. Diurnal blood pressure change varies with stroke subtype in the acute phase. Stroke 1998; 29: 1519- 24.

141 Sander D and Klingelhofer J. Changes of circadian blood pressure patterns and cardiovascular parameters indicate lateralisation of sympathetic activation following hemispheric brain infarction. Journal of Neurology 1995; 242: 313- 18.

142 Robinson T, Ward- Close S, Potter JA . Comparison of beat- to - beat blood pressure variability in acute and subacute stroke patients with cerebral infarction. Cerebrovascular Diseases 1997; 7: 214- 19.

143 Korpelainen JT, Sotaniemi KA, Huikuri HV et al. Circadian rhythm of heart rate variability is reversibly abolished in ischaemic stroke. Stroke 1997; 28: 2150- 54.

144 Naver HK, Blomstrand C and Wallin BG Reduced heart rate variability after right- sided stroke. Stroke 1996; 27: 247- 51.

145 Korpelainen JT, Sotaniemi K A, Makikallio A et al. Dynamic behavior of heart rate in ischaemic stroke. Stroke 1999; 30: 1008- 13.

146 Boiten J. Lacunar stroke, a prospective clinical and radiological study. Thesis 1991.

147 Boiten J, Lodder J. Large striatocapsular infarcts: clinical presentation and pathogenesis in comparison with lacunar and cortical infarcts. Acta Neurologica Scandinavia 1992; 86: 298- 303.

148 Tuszynski M H, Petito C K and Levy D E. Risk factors and clinical manifestations of pathologically verified lacunar infarctions. Stroke 1989; 20: 990- 99.

149 Fisher C M . Capsular infarcts. The underlying vascular lesions. Archives of Neurology 1979; 36: 65- 73. 
150 Fisher C M. Cerebral miliary aneurysms in hypertension. American Journal of Pathology 1971; 66: 313- 30.

151 Lammie G A, Brannan F, Slattery J, Warlow C. Nonhypertensive cerebral small vessel disease. An autopsy study. Stroke 1997; 28: 2222- 29.

152 Lodder J, Bamford J M, Sandercock PAG et al. Are hypertension or cardiac embolism likely causes of lacunar infarction? Stroke 1990; 21: 375- 81.

153 Boiten J, Rothwell P M, Slattery J and Warlow C P. Frequency and degree of carotid stenosis in small centrum semiovale infarcts as compared to lacunar infarcts. Cerebrovascular Diseases 1997; 7: 138- 43.

154 Weiller C Ringelstein B Reiche W. The large striatocapsular infarct. A clinical and pathophysiological entity . Archives of Neurology 1990; 47: 1085- 91.

155 Bogousslavsky J, Regli F, Maeder P. Intracranial large artery disease and 'lacunar' infarction. Cerebrovascular Diseases 1991; 1: 154- 59.

156 Boiten J, Lodder J. Risk factors for lacunar infarction. In: Lacunar and other subcortical infarctions. Donnan G, Norrving B, Bamford $\mathrm{J}$ and Bogousslavsky eds.

157 Caplan L R. Intracranial branch atheromatous disease: a neglected, understudied and underused concept . Neurology 1989; 39: 1246- 50.

158 Bamford J M, Warlow C P. Evolution and testing of the lacunar hypothesis. Stroke 1988; 19: 1074- 82.

159 Spolveri S, Baruffi M C, Cappelletti et al. Vascular risk factors linkd to multiple lacunar infarcts. Cerebrovascular Diseases 1998; 8: 152 - 57.

160 Van Swieten J C, van den Hout H W, van Ketel B A. Periventricular lesions in the white matter on magnetic resonance imaging in the elderly. Brain 1991; 114: 761- 74.

161 Marshall V G, Bradley Jr W G, Marshall C E et al. Deep white matter infarction: correlation of MR imaging and histopathologic findings. Radiology 1988; 167: 517- 22.

162 Chimowitz M I, Awad I A and Furlan A. Periventricular lesions on MRI. Facts and theories. Stroke 1989; 24: 7-12.

163 Gilman S. Imaging the brain. First of two parts. The New England journal of Medicine 1998; 338: 812- 20.

164 Steingard A, Hachinski VC Lau C et al. Cognitive and neurologic findings in subjects with diffuse white matter lucencies on computed tomographic scan (leuko- araiosis). Archives of Neurology 1987; 44: 32- 35.

165 Longstreth Jr W T, Manolio T A, Arnold A et al. Clinical correlates of white matter findings on cranial magnetic resonance imaging of 3301 elderly people. Stroke 1996; 27: 1274- 82.

166 Kobari M, Meyer J S, Ichijo Orvarez W T. Leukoaraiosis: correlation of MR and CT findings with blood flow, atrophy and cognition. American Journal of Neuro Radiology 1990: 11: 272- 81. 
167 Fazekas F, Kleinert R, Offenbacher $\mathrm{H}$ et al . Pathologic correlates of incidental MRI white matter signal hyperintensities. Neurology 1993; 43: 1683- 89.

168 Adachi T, Takagi M, Hoshino H Inafuku T . Effect of extracranial carotid artery stenosis and other risk factors for stroke on periventricular hyperintensity . Stroke 1997: 28: 2174- 79.

169 Chamorro A, Pujol Jm Saiz A et al. Periventricular white matter lucencies in patients with lacunar stroke. Archives of Neurology 1997; 54: 1284- 88.

170 Fazekas F. Magnetic resonance signal abnormalities in asymptomatic individuals: their incidence and functional correlates. European Neurology 1989; 29: 164- 68.

171 Braffman B H, Zimmerman R A Trojanowski J Q. Brain MR: pathologic correlation with gross and histopathology. 1 Lacunar infarction and Virchow- Robin spaces. American Journal of Neuro Radiology 1988; 9: 621- 28.

172 Braffman B H, Zimmerman R A, Trojanowski J Q. Brain MR: pathologic correlation with gross and histopathology. 2 Hyperintense white matter foci in the elderly. American Journal of Neuro Radiology 1988; 9: 629- 36.

173 Heier L A .Large Virchow- Robin spaces: MR- clinical correlation. American Journal of Neuro Radiology 1989; 10: 929- 36.

174 Ramadan N M, Deveshwar R, and Levine S R. Magnetic Resonance and clinical cerebrovascular disease. An update. Stroke 1989; 20: 1279- 83.

175 Brown J J, Hesselink J R, Rothrock J F. MR and CT of lacunar infarcts. American Journal of Neuro Radiology 1988; 9: 477- 82.

176 Sze G, De Armond S, Brant- Zawadzki M et al. Foci of MRI Signal (Pseudo Lesions) anterior to the frontal horns: Histologic correlations of a normal finding. American Journal of Radiology 1986: 147: 331- 37.

177 Breteler M M B, van Swieten J C, Bots M L et al. Cerebral white matter lesions, vascular risk factors, and cognitive function in a populationbased study: the Rotterdam study. Neurology 1994; 44: 1246- 52.

178 Bradley W G . Patchy periventricular white matter lesions in the elderly: common observation during NMR imaging. Noninvasive Medical Imaging 1984; 1: 35- 41.

179 Bots M , van Swieten J C, Breteler M et al. Cerebral white matter lesions and atherosclerosis in the Rotterdam study. Lancet 1993; 341: 1232- 37.

180 Fazekas F, Niederkorn K, Schmidt R et al . White matter signal abnormalities in normal individuals: correlation with carotid ultrasonography, cerebral blood flow measurements and cerebrovascular risk factors. Stroke 1988; 19: 1285- 88.

181 Claus J J, Breteler M M B, Hasan D et al. Vascular risk factors, atherosclerosis, cerebral white matter lesions and cerebral perfusion in a population-based study. European Journal of Nuclear Medicine 1996; 23 : 675- 82.

182 Ylikoski A, Erkinjutti T, Raininko R, et al. White matter hyperintensities on MRI in the neurologically nondiseased elderly. Stroke 1995: 26: 1171- 77. 
183 Miyazawa N, Satoh T, Hashizume K and Fukamachi A. Xenon- contrast CT- CBF measurements in high- intensity foci on T2- weighted MR images in the centrum semiovale of asymptomatic individuals. Stroke 1997; 28: 984- 87.

184 Kobayashi S, Okada K, Koide H, Bokura H et al. Subcortical silent brain infarction as a risk factor for clinical stroke. Stroke 1997; 28: 1932- 39.

185 Boon A, Lodder J, Heuts- van Raak L and Kessels F. Silent brain infarcts in 755 consecutive patients with a first- ever supratentorial ischaemic stroke. Relationship with index- stroke- subtype, vascular risk factors and mortality. Stroke 1994; 25: 2384- 90.

186 Streifer J, Eliaziw M, Benavente O R et al. Lack of relationship between leukoaraiosis and carotid artery disease. Archives of Neurology 1995; 52: 21- 24.

187 Schmidt R S, Fazekas F, Kleinert G et al. Magnetic resonance imaging signal hyperintensities in the deep and subcortical white matter: a comparative study between stroke patients and normal volounteers. Archives of Neurology 1992; 49: 825- 27.

188 Mancia G, Frattola A, Groppelli A et al. Blood pressure reduction and endorgan damage in hypertension. Journal of Hypertension 1994; 12: (suppl 8) S35- S42.

189 Goldstein I B, Bartzokis G, Hance D B Shapiro D . Relationship between blood pressure and subcortical lesions in healthy, elderly people. Stroke 1998; 29: 765- 72.

190 Uehara T, Tabuchi M and Mori E. Risk factors for silent cerebral infarcts in subcortical white matter and basal ganglia. Stroke 1999; 30: 378- 82.

191 Van Zagten M. Cerebral small vessel disease. Vascular risk factor profiles, clinical manifestations and disease progress in stroke. Thesis 1997.

192 Fukuda H, Kitani M . Differences between treated and untreated hypertensive subjects in the extent of periventricular hyperintensities observed on brain MRI. Stroke 1995; 26: 1593- 97.

193 Chimowitz M I, Estes M L, Furlan A J . Further observations on the pathology of subcortical lesions identified on magnetic resonance imaging. Archives of Neurology 1992: 49: 744- 52.

194 Awad I A, Johnsson P C, Spetzler R F, and Hodak J A . Incidental subcortical lesions identified on magnetic resonance imaging in the elderly II. Postmortem pathological correlations. Stroke 1986; 17: 1090- 97.

195 Kirkpatrick J B, Hayman L A. White matter lesions in MR imaging of clinically healthy brains of elderly subjects: possible pathological basis. Radiology 1987; 162: 509- 11.

196 Fazekas F, Kleinert R, Offenbacher $\mathrm{H}$ et al. The morphologic correlate of incidental punctate white matter hyperintensities on MR images. American Journal of Neuro Radiology 1991; 12: 915- 21.

197 Munoz D G, Haskat S M, Harper B et al. Pathologic correlates of increased signals of the centrum ovale on magnetic resonance imaging. Archives of Neurology 1993; 50: 492- 97. 
198 Van Zagten M, Boiten J, Kessels F and Lodder J. Significant progression of white matter lesions and small deep (lacunar) infarcts in patients with stroke. Archives of Neurology 1996; 53: 650- 55.

199 Isaka Y, Okamoto M, Ashida K, Imaizumi M . Decreased cerebrovascular dilatory capacity in subjects with asymptomatic periventricular hyperintensities. Stroke 1994; 25: 375- 81.

200 Metsemakers JF, Knottnerus JA, Kocken RJ et al. Unlocking patients' records in general practice for research, medical education and quality assurance: the Registration Family Pratices. International Journal of Biomedical Computing 1996; 42 (1-2): 43- 50.

201 Jolles J, Houx PJ, van Boxtel MPJ and Ponds RWHM (eds). Maastricht Ageing Study: Determinants of cognitive aging. Maastricht 1995, Neuropsych. publishers.

202 Bokura H, Kobayashi S and Yamaguchi S. Distinguishing silent lacunar infarction from enlarged Virchow- Robin spaces: a magnetic resonance imaging and pathological study. Journal of Neurology 1998; 245: 116- 22.

203 Boiten J, Lodder J. Isolated monoparesis is usually caused by superficial infarction. Cerebrovascular Diseases 1991; 1: 337- 40.

204 Arboix A, Marti- Vilalta J L, Pujol J et al. Lacunar cerebral infarct and nuclear magnetic resonance. European Neurology 1990; 30: 47- 51.

$205 \mathrm{Hommel}$ et al. Prospective study of lacunar infarction using magnetic resonance imaging. Stroke 1990; 21: 546- 54. 
Ariane de Wilde was born on july 24th 1969 in Eindhoven, blissfully unaware that men had just recently completed a giant step for mankind. Primary school was completed playfully, and she dreamed of becoming a doctor. No better place to prepare for university then, than in the land of Hippocrates himself. After consulting the oracle at Delphi and learning from Aesclepios at Argos she completed her General Certificate of Education at TASIS Hellenic International school as valedictorian of the class of 1987. The next ten years were spent in Maastricht, first at a young and ambitious university, and then completing the study that resulted in this thesis at the department of neurology. Specializing in occupational health today, she is confronted with a wide variety of interesting challenges. In the future she will always follow her dreams. 